\title{
Solid State Reactions Involving Oxides of Trivalent Cations
}

\author{
S. J. Schneider, R. S. Roth, and J. L. Waring
}

(April 11, 1961)

\begin{abstract}
Selected mixtures in 69 binary systems involving $\mathrm{Al}_{2} \mathrm{O}_{3}, \mathrm{Ga}_{2} \mathrm{O}_{3}, \mathrm{Cr}_{2} \mathrm{O}_{3}, \mathrm{Fe}_{2} \mathrm{O}_{3}, \mathrm{Sc}_{2} \mathrm{O}_{3}, \mathrm{In}_{2} \mathrm{O}_{3}$, $\mathrm{Y}_{2} \mathrm{O}_{3}$, and the rare earth oxides were studied by $\mathrm{X}$-ray diffraction techniques after heat treatment at various temperatures. A plot of the radii of the $\mathbf{A}^{+3}$ cations versus the radii of $\mathrm{B}^{+3}$ cations shows the regions of stability for the different structure types found for the double oxides of the trivalent cations. The following structure types were encountered: A, B, and C-type rare earth oxide; corundum, beta gallia; kappa alumina; garnet; perovskite; and several types which could not be definitely related to known structures. The majority of $\mathrm{A}^{+3} \mathrm{~B}^{+3} \mathrm{O}_{3}$ compounds have the perovskite structure. Several phases, including (1-x) $\mathrm{Fe}_{2} \mathrm{O}_{3} \cdot x \mathrm{Al}_{2} \mathrm{O}_{3}$ ss and $(1-x) \mathrm{Fe}_{2} \mathrm{O}_{3} \cdot x \mathrm{Ga}_{2} \mathrm{O}_{3}$ ss, appear to have structures similar to kappa alumina. Solid solution definitely occurs in many of the garnet type compounds which contain gallia. Based on the data collected in this survey, the subsolidus phase equilibria relationships of 79 binary systems were drawn.
\end{abstract}

\section{Introduction}

In the field of phase equilibria research it is often beneficial to first survey a series of related systems before ommencing on a detailed analysis of specific systems. A survey was recently conducted by the authors $[1]^{1}$ on the various solid state reactions that occur in mixtures of the trivalent rare earth oxides. It was found in the work that ionic size was the primary controlling factor in determining the various subsolidus phase relationships. This study has since been extended to include the oxides of the smaller trivalent cations, $\mathrm{In}^{+3}, \mathrm{Se}^{+3}, \mathrm{Fe}^{+3}, \mathrm{Cr}^{+3}, \mathrm{Ga}^{+3}$, and $\mathrm{Al}^{+3}$. These cations, together with the lanthanide series comprise almost the entire group of ions which are commonly trivalent.

To date, only a limited number of binary oxide systems involving only trivalent cations have been completely studied. With the exception of the previously mentioned paper by Schneider and Roth [1], most of the research has been concerned with studies of $\mathrm{A}^{+3} \mathrm{~B}^{+3} \mathrm{O}_{3}$ and to a lesser extent $\mathrm{A}_{3}{ }^{+3} \mathrm{~B}_{5}{ }^{+3} \mathrm{O}_{12}$ type compounds. The $\mathrm{A}^{+3} \mathrm{~B}^{+3} \mathrm{O}_{3}$ and $\mathrm{A}_{3}{ }^{+3} \mathrm{~B}_{5}{ }^{+3} \mathrm{O}_{12}$ compounds have the perovskite and garnet structures respectively. It is noteworth that the oxides of the trivalent cations, $\mathrm{A}_{2}{ }^{+3} \mathrm{O}_{3}$, may be considered in a general way as $\mathrm{A}^{+3} \mathrm{~B}^{+3} \mathrm{O}_{3}\left(\mathrm{~A}^{+3} \mathrm{~A}^{+3} \mathrm{O}_{3}\right)$ type compounds. None of these $\mathrm{A}_{2}{ }^{+3} \mathrm{O}_{3}$ oxides, however, are known to have a perovskite structure. Goldschmidt and his coworkers [2] were perhaps the first to investigate $\mathrm{A}^{+3} \mathrm{~B}^{+3} \mathrm{O}_{3}$ compounds in detail. Many other investigators, including Keith and Roy [3], Roth [4], and Geller and his coworkers [5, 6, 7] have substantially contributed to the data available on this formula-type compound.

The purpose of the present investigation was to survey the various structure types that occur under equilibrium conditions for different binary mixtures of the oxides of the trivalent cations and to establish the subsolidus phase equilibria relationships for

\footnotetext{
1 Figures in brackets indicatet he literature references at the end of this paper.
}

various systems. Special emphasis was given to a classification of the structure types found for equimolar mixtures according to the ionic radii of the constituent cations.

\section{Sample Preparation and Test Methods}

With the exception of $\mathrm{Cr}_{2} \mathrm{O}_{3}$ and $\mathrm{Fe}_{2} \mathrm{O}_{3}$ which were reagent grade, the materials used in this investigation had a purity of about 99.9 percent. Specimens were prepared from either 0.5 or 1.0 gram batches of various binary combinations of different oxides. Calculated amounts of each end member, corrected for ignition loss, were weighed to the nearest milligram. Each batch was mixed, formed into a $3 / 8$ in.-diam pellet by pressing at $10,000 \mathrm{lb} / \mathrm{in}^{2}$ and fired at some relatively low temperature (at least $800{ }^{\circ} \mathrm{C}$ ) for varying lengths of time. Most of the specimens were then ground, remixed, again pressed into pellets and fired at successively higher temperatures until equilibrium was obtained.

All specimens containing $\mathrm{In}_{2} \mathrm{O}_{3}$ or $\mathrm{Cr}_{2} \mathrm{O}_{3}$, were ground, mixed, and then sealed in platinum tubes for the higher temperature heat treatments. The duration and temperature of each heat treatment generally varied with the particular system under consideration. In general, the specimens were slow cooled at approximately $4^{\circ} \mathrm{C} / \mathrm{min}$. However, a few of the mixtures were quenched from elevated temperatures.

All heatings were performed in an air atmosphere using a conventional muffle furnace for the low temperature heats and a program-controlled tube furnace or a manually operated quench furnace for the heat treatment between 1000 and $1650{ }^{\circ} \mathrm{C}$. An induction furnace, having as the susceptor a small iridium crucible, was used for heat treatments above $1650{ }^{\circ} \mathrm{C}$. Temperatures were controlled to at least $\pm 10{ }^{\circ} \mathrm{C}$.

Equilibrium was considered to have been attained when the X-ray patterns of a specimen showed no change with successive heat treatment of the speci- 
men or when the X-ray powder data was consistent with the results predicted from a previous set of experiments. All specimens were examined at room temperature by X-ray diffraction with a Geigercounter diffractometer employing nickel-filtered copper radiation.

\section{Results}

The data obtained in this investigation are given in table 1 . The table lists six groups of binary systems, each having either $\mathrm{Al}_{2} \mathrm{O}_{3}, \mathrm{Ga}_{2} \mathrm{O}_{3}, \mathrm{Cr}_{2} \mathrm{O}_{3}$, $\mathrm{Fe}_{2} \mathrm{O}_{3}, \mathrm{Sc}_{2} \mathrm{O}_{3}$, or $\mathrm{In}_{2} \mathrm{O}_{3}$ as one component. Each of these groups in turn is arranged according to decreasing cation size of the second component. Selected literature references are included for compositions not studied experimentally in the present work. No attempt was made to incorporate into the table any data pertaining solely to mixtures involving only oxides of the trivalent rare earth cations. These data were reported in a recent publication by Schneider and Roth [1]. The table was designed primarily to present sufficient data to estimate the subsolidus phase relationships of a majority of the listed binary systems.

Figure 1 gives a classification of the various structure types found for equimolar mixtures of the oxides of the trivalent cations. The coordinates of the figure are the radii of the $\mathrm{A}^{+3}$ and $\mathrm{B}^{+3}$ cations. For convenience the larger cation in any mixture is taken as the $\mathrm{A}^{+3}$ cation (ordinate) and the smaller as $\mathrm{B}^{+3}$ (abscissa). The radii of the different cations are indicated on the figure by open triangles. ${ }^{2}$ The solid triangles on the diagonal line represent the

2 Radii values are according to Ahrens [8] with the exception of $\mathrm{Y}^{+3}, \mathrm{In}^{+3}$ and $\mathrm{Sc}^{+3}$ which were taken from Roth and Schneider [9]. The following radii values were used throughout this report: $\mathrm{La}^{+3}-1.14 \mathrm{~A}$, $\mathrm{Ce}^{+3-1.07} \mathrm{~A}, \mathrm{Pr}^{+3}-1.06 \mathrm{~A}, \mathrm{Nd}^{+3}$ $1.04 \mathrm{~A}, \mathrm{Sm}^{+3}-1.00 \mathrm{~A}, \mathrm{Eu}^{+3}-.98 \mathrm{~A}, \mathrm{Gd}^{+3}-.97 \mathrm{~A}, \mathrm{~Tb}^{+3}-.93 \mathrm{~A}, \mathrm{Dy}^{+3-} .92 \mathrm{~A}, \mathrm{Ho}^{+3-} .91$
$\mathrm{~A}, \mathrm{Y}^{+3} \sim$.

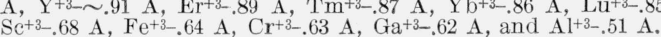

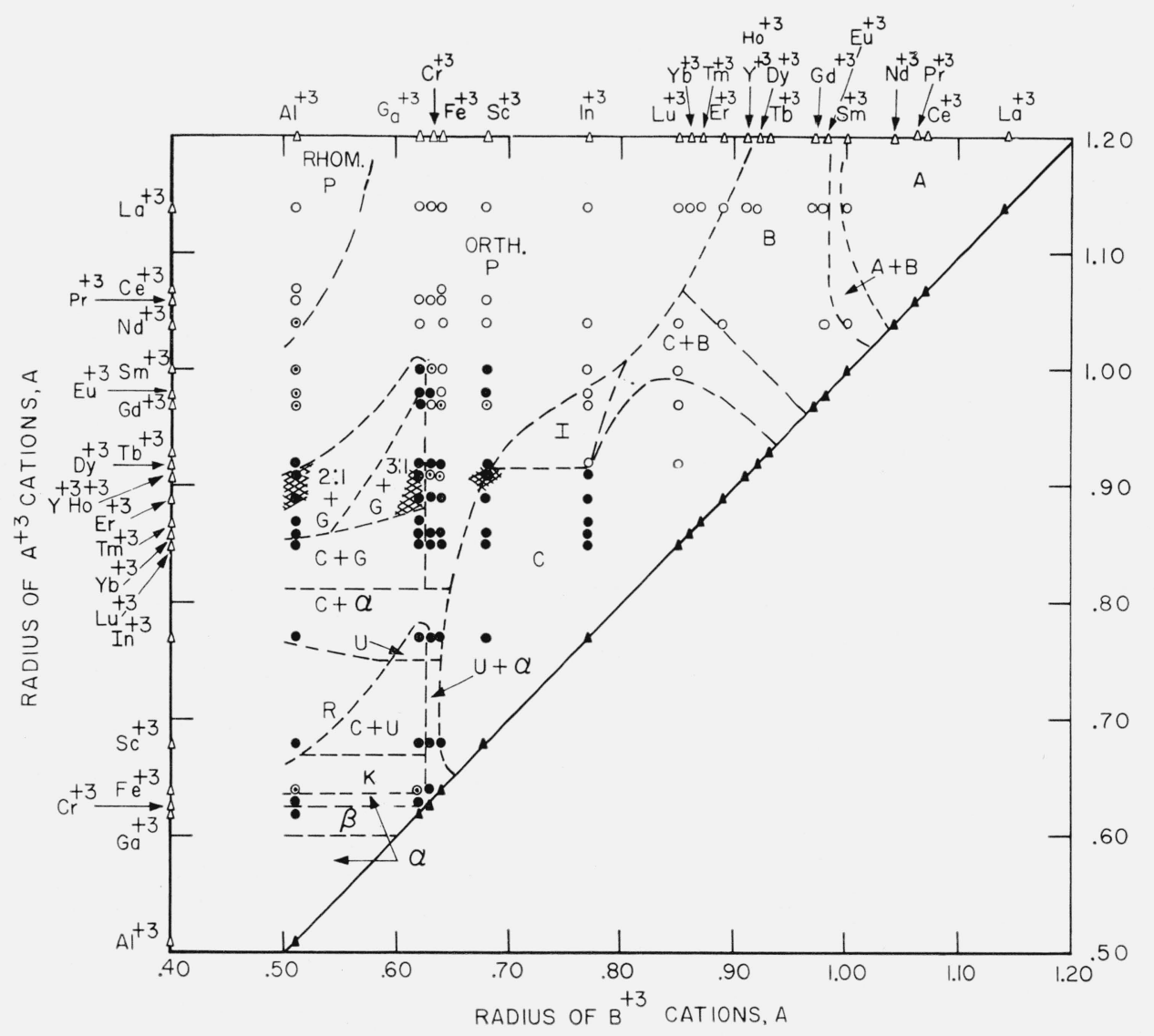

Figure 1. Classification of structure types for equimolar mixtures of trivalent cations.

$\triangle$-radii of cations

A-pure oxide

- compositions studied in present work

- data taken from literature

A-A-type rare earth oxide

$\mathrm{B}$ - B-type rare earth oxide

$\mathrm{C}-\mathrm{C}$-type rare earth oxide

G-garnet

I-unknown type

$\alpha-$ corundum

$\beta$-beta gallia
$\mathrm{K}$-kappa alumina

U-unknown type similar to kappa alumina

$\mathrm{P}$-perovskite

$\mathrm{R}$ - unknown type

2:1-unknown type

3:1-unknown type 
individual oxides. Each circle represents an equimolar composition containing either one or two phases which have the indicated structures at room temperature. In most instances, these same types also exist stably at elevated temperatures. The one known exception to this is the listed structure of the 1:1 mixture of $\mathrm{Fe}_{2} \mathrm{O}_{3}$ and $\mathrm{Al}_{2} \mathrm{O}_{3}$ which is metastable at room temperature [10]. The diagram does not indicate any reversible phase transformations or decompositions that occur at elevated temperatures. It should be emphasized that the boundaries outlining each field were arbitrarily drawn. They do not indicate the division of different structure types for solid solutions which may exist between adjacent equimolar mixtures.

The occurrence of metastable phases was prevalent in a number of the double oxides which are near the boundary lines of figure 1 . It was extremely difficult at times to establish the equilibrium phases. For this reason certain areas in the diagram are shaded to indicate that the position of certain portions of the boundary lines are somewhat in doubt. Several of these borderline systems are now being investigated in detail by the authors in order that the equilibrium phases can be definitely ascertained.

The majority of $\mathrm{A}^{+3} \dot{\mathrm{B}}^{+3} \mathrm{O}_{3}$ type compounds formed from double oxides of the trivalent cations are those having the perovskite structure. This field of perovskite types encompasses the largest single phase area of the diagram. The other single phase areas generally represent solid solutions and not true compounds. The two-phase areas, of course, contain compounds $(3: 1,2: 1$, and $3: 5)$ but not of the $\mathrm{A}^{+3} \mathrm{~B}^{+3} \mathrm{O}_{3}$ type.

Figure 1 not only designates the structure types for equimolar mixtures but also, with two exceptions, is applicable for all molar ratios of binary combinations of oxides of the listed cations. The two exceptions are the beta alumina $\left(\mathrm{La}_{2} \mathrm{O}_{3}-\mathrm{Al}_{2} \mathrm{O}_{3}\right.$ and $\mathrm{La}_{2} \mathrm{O}_{3}-\mathrm{Fe}_{2} \mathrm{O}_{3}$ systems $)$ and the spinel $\left(\mathrm{Fe}_{2} \mathrm{O}_{3}-\mathrm{R}_{2} \mathrm{O}_{3}\right.$ systems $)$ structures. The spinel structure, of course, occurs only when $\mathrm{FeO}$ is present as a third component. The various structure types are discussed in succeeding sections.

\section{Discussion}

\subsection{A, B, C, Beta Gallia, and Corundum Structure Types}

The structure type of the stable forms of the oxides of the trivalent cations (fig. 1, solid triangles) can be generally grouped in the following manner according to the ionic radius of the constituent cations: $1.14 \mathrm{~A}$ to $1.04 \mathrm{~A}$-hexagonal A-type rare earth oxide structure; $1.00 \mathrm{~A}$ to $0.97 \mathrm{~A}$-monoclinic B-type rare earth oxide structure; $0.93 \mathrm{~A}$ to $0.68 \mathrm{~A}$ cubic C-type rare earth oxide structure; $0.64 \mathrm{~A}$ to $0.63 \mathrm{~A}-\mathrm{rhombohedral}$ corundum structure; $0.62 \mathrm{~A}$ monoclinic beta gallia structure; and 0.51 A-rhombohedral corundum structure. In the above listing the structure types are seemingly out of order with respect to radii in that the beta gallia type is inter- mediate between two corundum types. This inconsistency emphasizes that other factors besides radii must be considered in generalizations such as given above.

Generally the effects of partial covalent bonding in essentially ionic type materials are neglected. Mooser and Pearson [11] related the structures of certain simple compounds to average quantum numbers and electronegativity values. From their work and others $[11,12]$ it is apparent that the covalent character (directional properties of the bonds) of a compound is directly related to the difference in the electronegativities of the cation and anion. Generally the greater the difference, the less the covalent type bonding. Using the electronegativity values given by Gordy and Thomas [13] to calculate relative covalent character, the aforementioned grouping of structure types can be rearranged according to increasing covalent character: $\mathrm{A}, \mathrm{B}$, or $\mathrm{C}$ types $\left(\mathrm{Ln}_{2} \mathrm{O}_{3}\right)^{3}$ C-type $\left(\mathrm{Sc}_{2} \mathrm{O}_{3}\right)<$ C-type $\left(\mathrm{In}_{2} \mathrm{O}_{3}\right)<$ beta gallia type $\left(\mathrm{Ga}_{2} \mathrm{O}_{3}\right)<$ corundum type $\left(\mathrm{Al}_{2} \mathrm{O}_{3}\right)<$ corundum type $\left(\mathrm{Cr}_{2} \mathrm{O}_{3}\right)<$ corundum type $\left(\mathrm{Fe}_{2} \mathrm{O}_{3}\right)$. This method of arrangement, although on a very relative scale, does group like structure types together. It would be increasingly more difficult to apply this type of classification to compounds containing ions of different valence as well as those containing multiple ions of the same valence.

A number of the trivalent oxides have metastable polymorphs which have structures different from the stable modifications. A B-type structure has been reported for $\mathrm{Nd}_{2} \mathrm{O}_{3}$ [14], while $\mathrm{Sm}_{2} \mathrm{O}_{3}, \mathrm{Eu}_{2} \mathrm{O}_{3}$, and Gd $\mathrm{O}_{3}$ are known to form the C-type [9]. Gallia $\left(\mathrm{Ga}_{2} \mathrm{O}_{3}\right)$ and $\mathrm{Al}_{2} \mathrm{O}_{3}$ are similar in many respects in that they both have polymorphs of the same structure type. Gamma $\mathrm{Al}_{2} \mathrm{O}_{3}$ and gamma $\mathrm{Ga}_{2} \mathrm{O}_{3}$ are isostructural, as are alpha $\mathrm{Al}_{2} \mathrm{O}_{3}$ and alpha $\mathrm{Ga}_{2} \mathrm{O}_{3}$ [15]. This is also true for epsilon $\mathrm{Ga}_{2} \mathrm{O}_{3}$ and kappa $\mathrm{Al}_{2} \mathrm{O}_{3}$ and for beta $\mathrm{Ga}_{2} \mathrm{O}_{3}$ and theta $\mathrm{Al}_{2} \mathrm{O}_{3}$ [15]. $\mathrm{A}$ metastable polymorph of a pure oxide may appear as a stable phase in solid solutions. Examples of this occur in solid solutions between the oxides of the trivalent rare earth ions. For instance, the B-type structure in solid solutions is stable over a far greater range of average radii values than the pure oxides [1].

\subsection{Perovskite Structure Type}

The various combinations of double oxides that form 1:1 compounds which have the perovskite structure are indicated in figure 1. Each of these compounds has modifications which are distorted from the ideal cubic structure assuming either rhombohedral or orthorhombic symmetry at room temperature. At elevated temperatures other symmetries may occur. It has been suggested that the order of transformation with temperature is probably orthorhombic to rhombohedral to cubic [7].

Goldschmidt and coworkers [2] derived a tolerance factor $(t)$ for the perovskite structure which is

3 The symbol "Ln" represents the lanthanide series, lanthanum through lutecium. 
given by the following formula:

where

$$
t=\frac{R_{A}+R_{O}}{\sqrt{2}\left(R_{B}+R_{O}\right)}
$$

$$
\begin{aligned}
t & =\text { tolerance factor } \\
R_{A} & =\text { radius of larger cation } \\
R_{B} & =\text { radius of smaller cation } \\
R_{O} & =\text { radius of oxygen }(1.40 \mathrm{~A}) .
\end{aligned}
$$

As $t$ approaches unity, the tendency for the formation of a perovskite structure becomes greater. The lower limit or minimum value of $t$ for a given series can only be determined experimentally. For the $\mathrm{Ln}_{2} \mathrm{O}_{3} \cdot \mathrm{Ga}_{2} \mathrm{O}_{3}$ and $\mathrm{Ln}_{2} \mathrm{O}_{3} \cdot \mathrm{Al}_{2} \mathrm{O}_{3}$ series of perovskite type compounds, the minimum values of $t$ were found to be 0.85 and 0.84 respectively. In comparison, the lower limit of $t$ for the other perovskite type series, $\mathrm{La}_{2} \mathrm{O}_{3} \cdot \mathrm{Ln}_{2} \mathrm{O}_{3}$ [1], $\mathrm{Ln}_{2} \mathrm{O}_{3} \cdot \mathrm{In}_{2} \mathrm{O}_{3}, \mathrm{Ln}_{2} \mathrm{O}_{3}$. $\mathrm{Sc}_{2} \mathrm{O}_{3}, \mathrm{Ln}_{2} \mathrm{O}_{3} \cdot \mathrm{Fe}_{2} \mathrm{O}_{3}$ and $\mathrm{Ln}_{2} \mathrm{O}_{3} \cdot \mathrm{Cr}_{2} \mathrm{O}_{3}$, are all equal to about 0.78 .

Dalziel [16], considering only the $\mathrm{Fe}_{2} \mathrm{O}_{3}, \mathrm{Ga}_{2} \mathrm{O}_{3}$, and $\mathrm{Al}_{2} \mathrm{O}_{3}$ perovskite series, attempted to explain the differences in minimum $t$ values or the basis of partial covalent character of the non rare earth cation-oxygen bond. To test the relative covalent character of the different series, Dalziel presented a graph similar to that given in figure 2. Expanding Dalziel's graph to include all appropriate data in table 1, figure 2 shows the relationship between the volumes of the $\mathrm{Ln}^{+3}$ cations in 12 -fold coordination and the volumes of one formula weight of $\mathrm{Ln}_{2} \mathrm{O}_{3}$. $\mathrm{M}_{2} \mathrm{O}_{3}$ perovskite type compounds, as both determined experimentally (solid lines) and as predicted from the lanthanide contraction (dashed lines). For a given series, the volumes should decrease in a regular manner with the lanthanide contraction. The decrease, however, will be modified somewhat from that predicted, due to: (1) the deviation from close packing caused by increased distortion of the lattice and (2) the influence of covalent character of the cation-oxygen bonds [16]. The former would result in larger volumes than those predicted while the latter would produce an opposite effect.

In general, it can be concluded from figure 2 that for a given series, the covalent character significantly increases as the size of the $\mathrm{Ln}^{+3}$ cation decreases. It is difficult to compare the different series with regard to which group is more covalent because of

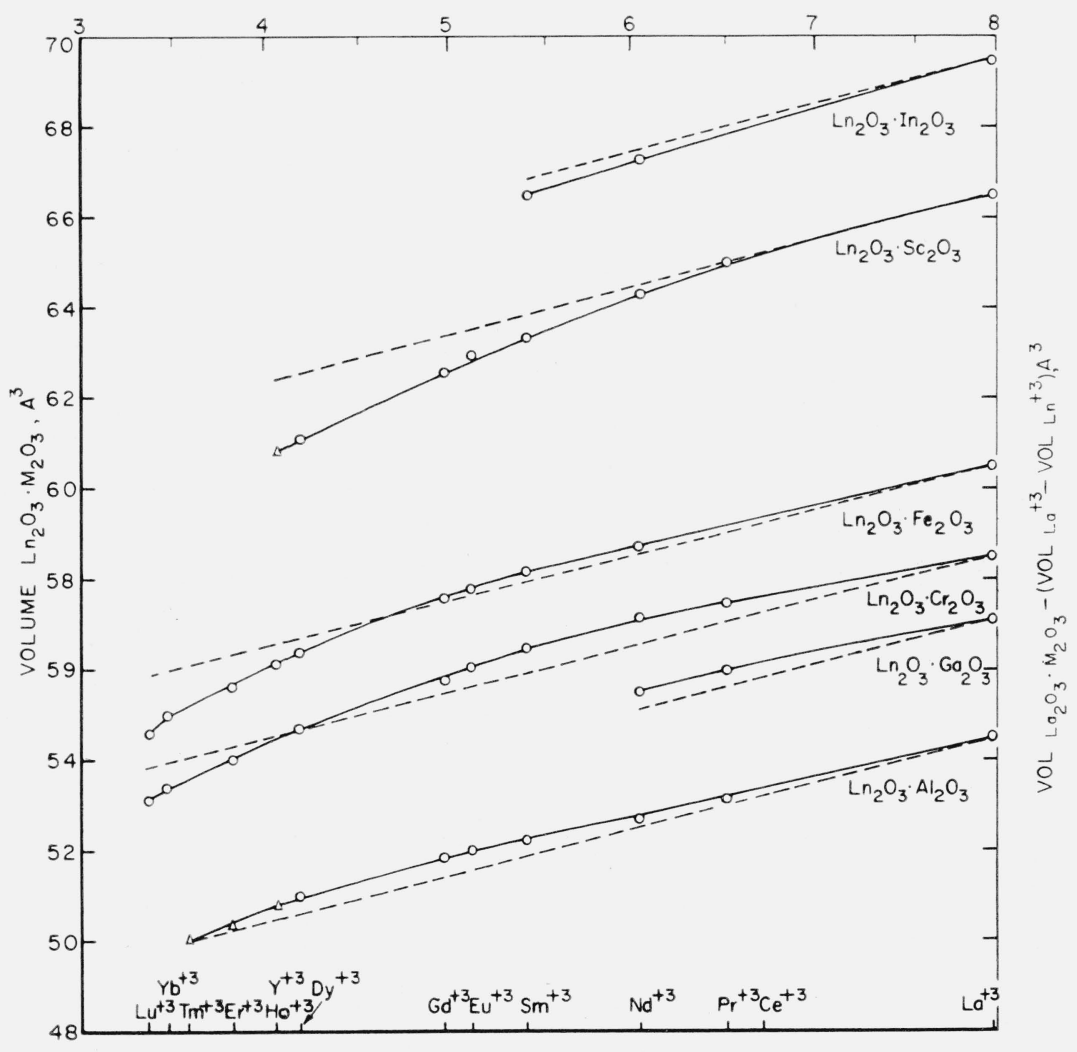

VOLUME OF $\operatorname{Ln}^{+3}, A^{3}$

FIGURE 2. Relationship between volumes of one formula weight of $\mathrm{Ln}_{2} \mathrm{O}_{3} \cdot \mathrm{M}_{2} \mathrm{O}_{3}$ perovskites and volumes of cations in 12-fold coordination. 
masking effects of the various factors. It does appear, however, that the effect of partial covalent bonding is less pronounced in the $\mathrm{Al}_{2} \mathrm{O}_{3}$ and perhaps the $\mathrm{Ga}_{2} \mathrm{O}_{3}$ series than in the other groups. This would account for the larger minimum tolerance factors of the $\mathrm{Al}_{2} \mathrm{O}_{3}$ and $\mathrm{Ga}_{2} \mathrm{O}_{3}$ series.

\subsection{Garnet Structure Type}

The garnet structure occurs at the ideal 3:5 molar ratio in a number of binary systems involving oxides of the trivalent cations. Specifically, these include systems containing either $\mathrm{Fe}_{2} \mathrm{O}_{3}, \mathrm{Ga}_{2} \mathrm{O}_{3}$, or $\mathrm{Al}_{2} \mathrm{O}_{3}$ as one end member and a rare earth oxide $\left(\right.$ or $\left.\mathrm{Y}_{2} \mathrm{O}_{3}\right)$ as the other. The chemical formula of a garnet type compound can be written as $\left[\mathrm{A}_{3}{ }^{+3}\right]\left[\mathrm{B}_{2}{ }^{+3}\right]\left[\mathrm{C}_{3}{ }^{+3}\right] \mathrm{O}_{12}$, where $\left[\mathrm{A}^{+3}\right],\left[\mathrm{B}^{+3}\right]$, and $\left[\mathrm{C}^{+3}\right]$ indicate cations which occur in 8-fold, 6-fold, and 4-fold coordination, respectively [17]. In binary systems the rare earth cations or $\mathrm{Y}^{+3}$ can be usually thought of as occupying the $\left[\mathrm{A}^{+3}\right]$ sites with the smaller cations, $\mathrm{Fe}^{+3}$, $\mathrm{Ga}^{+3}$, or $\mathrm{Al}^{+3}$ filling the $\left[\mathrm{B}^{+3}\right]$ and $\left[\mathrm{C}^{+3}\right]$ positions.

Compounds having the garnet structure do not occur in binary systems containing $\mathrm{Cr}_{2} \mathrm{O}_{3}$. This agrees with the observation [17] that $\mathrm{Cr}^{+3}$ prefers only octahedral type of coordination $\left(\left[\mathrm{B}^{+3}\right]\right.$ sites $)$ in the garnet structure. Apparently the $\mathrm{Cr}^{+3}$ cations will never appreciably occupy tetrahedral sites in the garnet structure, even when it is the most likely cation to be tetrahedrally coordinated.

Solid solution of the garnet type compounds which occurs in binary systems containing $\mathrm{Ga}_{2} \mathrm{O}_{3}$ has been generally overlooked because of the simultaneous report of solid solution between the perovskite and garnet structures in the $\mathrm{Y}_{2} \mathrm{O}_{3}-\mathrm{Al}_{2} \mathrm{O}_{3}$ system [3]. Solid solution definitely occurs in many binary gallia garnets. Figure 3 shows plots of the radii of the rare earth cations against both the compositional range of solid solution of the various garnet compounds (no. 1) and the corresponding change in unit cell dimensions (no. 2). In these garnet solid solutions, the rare earth cation apparently subsitutes for $\mathrm{Ga}^{+3}$ in the octahedral $\left(\left[\mathrm{B}^{+3}\right]\right)$ positions. ${ }^{4}$

The amount of solid solution as well as the amount of change in unit cell dimensions increases to a maximum at about $\mathrm{Tm}^{+3}$ as the size of the constituent rare earth cation decreases. The reason for this behavior is unknown. In addition, the values determined for the garnet solid solution in the $\mathrm{Y}_{2} \mathrm{O}_{3}$ $\mathrm{Ga}_{2} \mathrm{O}_{3}$ system were excessively larger than expected and do not fit the general curves of figure 3 .

It is interesting to observe that solid solution of the garnet type compound for the gallia series occurs only in binary systems in which a perovskite-type compound does not exist as a stable phase. On this premise it was considered likely and experimentally verified that solid solution does occur in the smaller alumina garnets, $3 \mathrm{Yb}_{2} \mathrm{O}_{3} \cdot 5 \mathrm{Al}_{2} \mathrm{O}_{3}$ and $3 \mathrm{Lu}_{2} \mathrm{O}_{3} \cdot 5 \mathrm{Al}_{2} \mathrm{O}_{3}$. Although not determined exactly, the extent of garnet solid solution is fairly small, probably about

${ }^{1}$ It has been suggested by S. Geller in a private communication that the solid solution may be of the interstitual and/or vacancy types instead of substitutional and thus result in a defect structure.

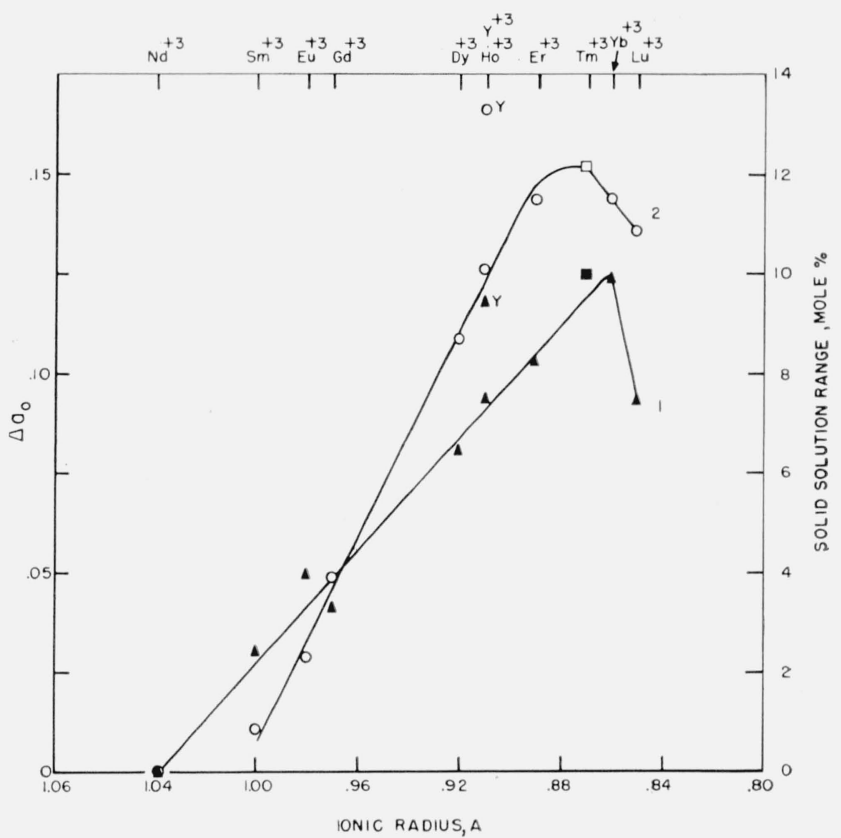

Figure 3. Relationship between ionic radii and both compositional range of solid solution and corresponding parameter change in several gallia garnets at $1500{ }^{\circ} \mathrm{C}$.

$$
\begin{gathered}
\text { Curve } 1 \text {-Solid solution range } \\
\text { Curve.2-Change in unit cell dimension } \\
\triangle \mathrm{a}_{0}=\mathrm{a}_{0} 1: 1-\mathrm{a}_{0} 3: 5 \\
\square \quad=\text { estimated }
\end{gathered}
$$

two mole percent. Substitutional type solid solution of the $\mathrm{Fe}_{2} \mathrm{O}_{3}$ garnets probably does not occur. However, as illustrated by the $\mathrm{Y}_{2} \mathrm{O}_{3}-\mathrm{Fe}_{2} \mathrm{O}_{3}$ system [18], partial reduction of $\mathrm{Fe}_{2} \mathrm{O}_{3}$ in these garnets may produce solid solution to a limited extent.

\subsection{Kappa Alumina Structure Type}

Considerable confusion exists in the literature with regard to the various low temperature, metastable polymorphs of $\mathrm{Al}_{2} \mathrm{O}_{3}$ and $\mathrm{Ga}_{2} \mathrm{O}_{3}$. These polytypes are ill-defined primarily because of the inability to obtain clear, interpretable X-ray diffraction data. Of particular interest in the present investigation are the kappa alumina and epsilon gallia polymorphs and their characteristic structures. Roy et al. [15] have clearly demonstrated through a series of solid solution studies that kappa alumina and epsilon gallia in reality have the same structure. The alumina polymorph having the kappa alumina structure has been reported [19] to be orthorhombic with $a=8.49 \mathrm{~A}, b=12.73 \mathrm{~A}$, and $c=13.39 \mathrm{~A}$. The reported $d$-spacings were not given with sufficient accuracy to verify the cell dimensions.

Richardson et al. [20] described the phase which occurs at the equimolar mixture of $\mathrm{Fe}_{2} \mathrm{O}_{3}$ and $\mathrm{Al}_{2} \mathrm{O}_{3}$ as having a structure similar to that of kappa alumina. The X-ray pattern for the $50 \mathrm{Fe}_{2} \mathrm{O}_{3}$ : $50 \mathrm{Al}_{2} \mathrm{O}_{3}$ phase was indexed by Richardson et al. [20] on the basis of an orthorhombic cell with $a=7.03 \mathrm{~A}$, $b=6.33 \mathrm{~A}$, and $c=7.41 \mathrm{~A}^{5} \quad$ However, the calculated

\footnotetext{
${ }_{5}$ Unit cell dimensions converted from $k X$ units.
} 
and observed $d$-spacings do not appear to be in close enough agreement to justify the reported indexing. In the present investigation three $\mathrm{Fe}_{2} \mathrm{O}_{3}-\mathrm{Al}_{2} \mathrm{O}_{3}$ mixtures, $47: 53,50: 50$, and $53: 47$ were prepared. Each specimen contained the same single phase as that reported by Richardson et al. [20]. The X-ray pattern of the $53 \mathrm{Fe}_{2} \mathrm{O}_{3}: 47 \mathrm{Al}_{2} \mathrm{O}_{3}$ specimen was successfully indexed on the basis of an orthorhombic cell with $a=8.59 \mathrm{~A}, b=9.23 \mathrm{~A}$, and $c=4.98 \mathrm{~A}$ as given in table 2 . The indexing was accomplished only after comparison with the X-ray pattern of the $50 \mathrm{Fe}_{2} \mathrm{O}_{3}: 50 \mathrm{Ga}_{2} \mathrm{O}_{3}$ specimen, a phase described by Wood [21]. The orthorhombic phases which occur in the $\mathrm{Fe}_{2} \mathrm{O}_{3}-\mathrm{Al}_{2} \mathrm{O}_{3}$ and $\mathrm{Fe}_{2} \mathrm{O}_{3}-\mathrm{Ga}_{2} \mathrm{O}_{3}$ systems are apparently isostructural and represent solid solutions rather than compounds. The similarity in structures is important because of the reported magnetic and piezoelectric properties of the $(1-x) \mathrm{Fe}_{2} \mathrm{O}_{3} \cdot x \mathrm{Ga}_{2} \mathrm{O}_{3}$ ss phase. These properties in $(1-x) \mathrm{Fe}_{2} \mathrm{O}_{3} \cdot x \mathrm{Al}_{2} \mathrm{O}_{3 s s}$ will be reported on in a future publication. Muan and Somiya [10] reported the complete phase relations for the $\mathrm{Fe}_{2} \mathrm{O}_{3}-\mathrm{Al}_{2} \mathrm{O}_{3}$ system and showed that the orthorhombic phase has both a minimum and maximum decomposition temperature.

There is not yet sufficient evidence to classify the orthorhombic phases of the $\mathrm{Fe}_{2} \mathrm{O}_{3}-\mathrm{Al}_{2} \mathrm{O}_{3}$ and $\mathrm{Fe}_{2} \mathrm{O}_{3}$ $\mathrm{Ga}_{2} \mathrm{O}_{3}$ systems as having a kappa alumina structure although there is a definite similarity. The X-ray patterns given in the literature for the kappa alumina and epsilon gallia polymorphs could not be indexed on the same basis as that given for $53 \mathrm{Fe}_{2} \mathrm{O}_{3}: 47 \mathrm{Al}_{2} \mathrm{O}_{3}$ in table 2. The failure to index these patterns may be due to the inaccurate X-ray data available rather than dissimilar structures.
TABLE 2. X-ray powder diffraction data for $(1-x) \mathrm{Fe}_{2} \mathrm{O}_{3} \cdot x \mathrm{Al}_{2} \mathrm{O}_{3}$ ss

$\left(53 \mathrm{Fe}_{2} \mathrm{O}_{3}: 47 \mathrm{Al}_{2} \mathrm{O}_{3}\right.$ mixture)

\begin{tabular}{|c|c|c|c|c|}
\hline \multirow{2}{*}{$h k l^{1}$} & \multirow{2}{*}{$d^{2}$} & \multirow{2}{*}{$I^{3}$} & \multicolumn{2}{|c|}{$\frac{1}{d^{2}}$} \\
\hline & & & obs & cal \\
\hline $\begin{array}{l}100 \\
020 \\
111 \\
121 \\
220\end{array}$ & $\begin{array}{l}\text { A } \\
6.03 \\
4.64 \\
3.90 \\
3.144\end{array}$ & $\begin{array}{l}25 \\
23 \\
18 \\
38\end{array}$ & $\begin{array}{c}A^{-2} \\
0.0253 \\
.0464 \\
.0657 \\
.1012\end{array}$ & $\begin{array}{c}A^{-2} \\
0.0253 \\
.0470 \\
.0656 \\
.1008 \\
.1012\end{array}$ \\
\hline $\begin{array}{l}130 \\
221 \\
131 \\
002 \\
012\end{array}$ & $\begin{array}{l}2.899 \\
2.658 \\
2.497 \\
2.407\end{array}$ & $\begin{array}{r}38 \\
100 \\
29 \\
18\end{array}$ & $\begin{array}{l}.1190 \\
.1415 \\
.1604 \\
.1726\end{array}$ & $\begin{array}{l}.1193 \\
.1415 \\
.1596 \\
.1610 \\
.1728\end{array}$ \\
\hline $\begin{array}{l}102 \\
311 \\
040 \\
022 \\
321\end{array}$ & $\begin{array}{l}2.393 \\
2.306 \\
2.193 \\
2.186\end{array}$ & $\begin{array}{l}34 \\
14 \\
23 \\
38\end{array}$ & $\begin{array}{l}.1747 \\
.1881 \\
.2080 \\
.2093\end{array}$ & $\begin{array}{l}.1746 \\
.1741 \\
.1881 \\
.2080 \\
.2093\end{array}$ \\
\hline $\begin{array}{l}400 \\
122 \\
331 \\
042 \\
123\end{array}$ & $\begin{array}{l}2.146 \\
2.125 \\
1.9000 \\
1.6920 \\
1.5377\end{array}$ & $\begin{array}{l}13 \\
21 \\
29 \\
20 \\
16\end{array}$ & $\begin{array}{l}.2171 \\
.2214 \\
.2679 \\
.3493 \\
.4226\end{array}$ & $\begin{array}{l}2171 \\
.2216 \\
.2681 \\
.3491 \\
.4229\end{array}$ \\
\hline
\end{tabular}

${ }^{1}$ Based on orthorhombic cell with $a=8.59 \mathrm{~A}, b=9.23 \mathrm{~A}$, and $c=4.98 \mathrm{~A}$.

2 Interplanar spacing.

${ }_{3}$ Relative intensity.

Figure 4, as well as table 3, presents X-ray powder data for all the phases encountered in this investigation which may have structures similar to kappa alumina. It is apparent, from figure 4, that the patterns for kappa alumina, epsilon gallia, $50 \mathrm{Fe}_{2} \mathrm{O}_{3}$ : $50 \mathrm{Al}_{2} \mathrm{O}_{3}$ and $50 \mathrm{Fe}_{2} \mathrm{O}_{3}: 50 \mathrm{Ga}_{2} \mathrm{O}_{3}$ are related. Each of the X-ray patterns of the other phases, $50 \operatorname{In}_{2} \mathrm{O}_{3}$ :

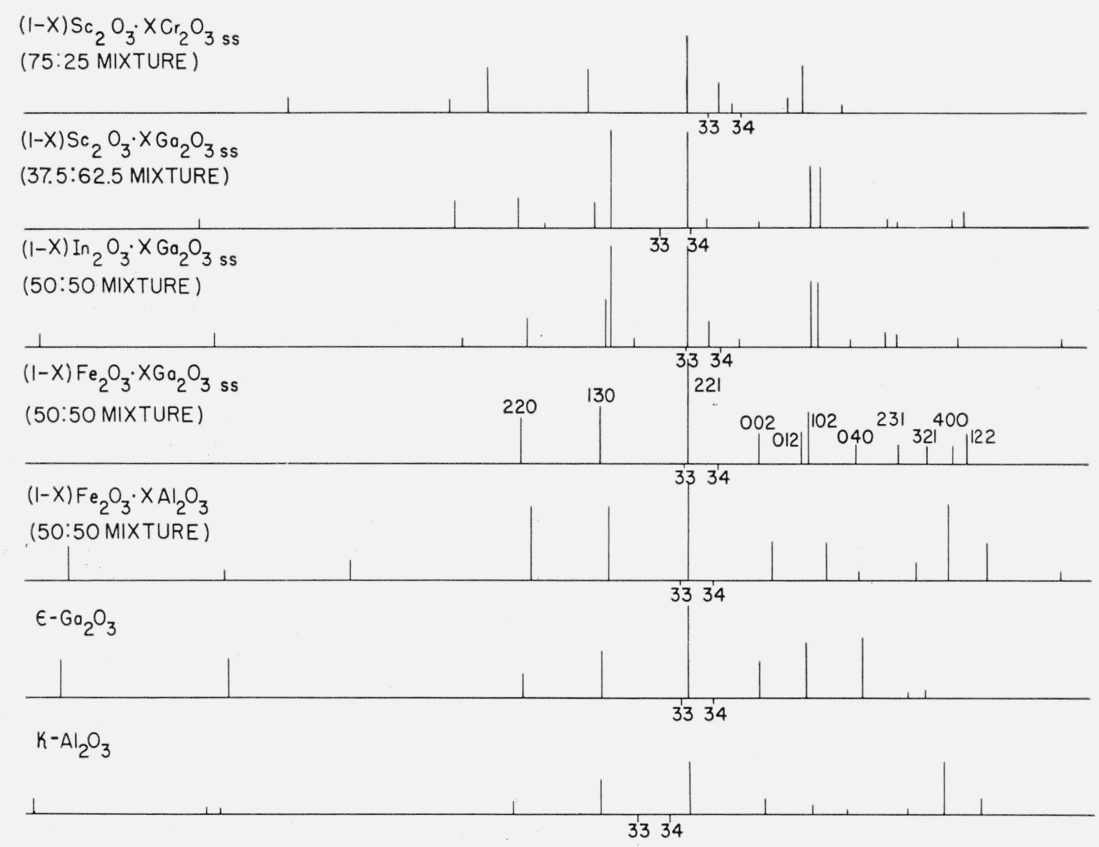

$2 \theta$, DEGREES,FOR Cu K $\alpha$ RADIATION

FIGURE 4. Diagrammatic X-ray powder diffraction patterns for kappa alumina [25], epsilon qallia [15], 50F $e_{2} \mathrm{O}_{3}: 50 \mathrm{Al}_{2} \mathrm{O}_{3}$ $50 \mathrm{Fe}_{2} \mathrm{O}_{3}: 50 \mathrm{Ga}_{2} \mathrm{O}_{3}, 50 \mathrm{In}_{2} \mathrm{O}_{3}: 50 \mathrm{Ga}_{2} \mathrm{O}_{3}, 37.5 \mathrm{Sc}_{2} \mathrm{O}_{3}: 62.5 \mathrm{Ga}_{2} \mathrm{O}_{3}$ and $75 \mathrm{Sc}_{2} \mathrm{O}_{3}: 25 \mathrm{Cr}_{2} \mathrm{O}_{3}$.

For the kappa alumina pattern, d-values apparently due to extraneous phases were deleted, as was done by Roy et al. [15]. 
TABLE 3. X-ray powder diffraction data for $(1-x) \mathrm{In}_{2} \mathrm{O}_{3}$. $x \mathrm{Ga}_{2} \mathrm{O}_{3}$ ss, $(1-x) \mathrm{Sc}_{2} \mathrm{O}_{3} \cdot x \mathrm{Ga}_{2} \mathrm{O}_{3}$ ss, and $(1-x) \mathrm{Sc}_{2} \mathrm{O}_{3} \cdot x \mathrm{Cr}_{2} \mathrm{O}_{3}$ ss

\begin{tabular}{|c|c|c|c|c|c|}
\hline \multicolumn{2}{|c|}{$\begin{array}{c}50 \mathrm{In}_{2} \mathrm{O}_{3}: 50 \mathrm{Ga}_{2} \mathrm{O}_{3} \\
\text { mixture }\end{array}$} & \multicolumn{2}{|c|}{$\begin{array}{c}37.5 \mathrm{Sc}_{2} \mathrm{O}_{3}: 62.5 \mathrm{Ga}_{2} \mathrm{O}_{3} \\
\text { mixture }\end{array}$} & \multicolumn{2}{|c|}{$\begin{array}{l}75 \mathrm{Sc}_{2} \mathrm{O}_{3}: 25 \mathrm{Cr}_{2} \mathrm{O}_{3} \\
\text { mixture }\end{array}$} \\
\hline$d^{1}$ & $I^{2}$ & $d^{1}$ & $I^{2}$ & $d^{1}$ & $I^{2}$ \\
\hline$A$ & & $A$ & & $A$ & \\
\hline $\begin{array}{l}9.72 \\
6.83 \\
4.88 \\
4.84 \\
3.423\end{array}$ & $\begin{array}{r}13 \\
18 \\
9 \\
17 \\
11\end{array}$ & $\begin{array}{l}4.73 \\
3.404 \\
3.110 \\
3.034 \\
2.889\end{array}$ & $\begin{array}{r}12 \\
36 \\
39 \\
8 \\
29\end{array}$ & $\begin{array}{l}4.44 \\
3.559 \\
3.400 \\
3.046 \\
2.763\end{array}$ & $\begin{array}{r}18 \\
21 \\
59 \\
57 \\
100\end{array}$ \\
\hline $\begin{array}{l}3.183 \\
2.279 \\
2.917 \\
2.851 \\
2.710\end{array}$ & $\begin{array}{r}37 \\
57 \\
100 \\
11 \\
100\end{array}$ & $\begin{array}{l}2.878 \\
2.852 \\
2.653 \\
2.598 \\
2.486\end{array}$ & $\begin{array}{r}100 \\
100 \\
88 \\
16 \\
11\end{array}$ & $\begin{array}{l}2.687 \\
2.653 \\
2.531 \\
2.501 \\
2.417\end{array}$ & $\begin{array}{r}45 \\
12 \\
15 \\
52 \\
9\end{array}$ \\
\hline $\begin{array}{l}2.661 \\
2.590 \\
2.437 \\
2.426 \\
2.363\end{array}$ & $\begin{array}{r}57 \\
9 \\
80 \\
80 \\
11\end{array}$ & $\begin{array}{l}2.385 \\
\text { 2. } 365 \\
2.247 \\
2.231 \\
2.144\end{array}$ & $\begin{array}{r}88 \\
90 \\
13 \\
8 \\
14\end{array}$ & $\begin{array}{l}1.9713 \\
1.9465 \\
1.9072 \\
1.7984 \\
1.7172\end{array}$ & $\begin{array}{l}13 \\
49 \\
80 \\
11 \\
16\end{array}$ \\
\hline $\begin{array}{l}\text { 2. } 298 \\
2.279 \\
2.177 \\
2.031 \\
1.9434\end{array}$ & $\begin{array}{r}15 \\
8 \\
13 \\
13 \\
8\end{array}$ & $\begin{array}{l}\text { 2. } 131 \\
\text { 1. } 830 \\
\text { 1. } 7905 \\
\text { 1. } 7836 \\
\text { 1. } 7077\end{array}$ & $\begin{array}{r}24 \\
6 \\
52 \\
39 \\
46\end{array}$ & $\begin{array}{l}\text { 1. } 6573 \\
\text { 1. } 6247 \\
\text { 1. } 6861 \\
\text { 1. } 4903 \\
1.4666\end{array}$ & $\begin{array}{l}49 \\
15 \\
27 \\
11 \\
15\end{array}$ \\
\hline $\begin{array}{l}19155 \\
1.8273 \\
1.8200 \\
1.7190 \\
1.6709\end{array}$ & $\begin{array}{r}9 \\
33 \\
34 \\
100 \\
8\end{array}$ & $\begin{array}{l}\text { 1. } 6800 \\
\text { 1. } 6017 \\
\text { 1. } 5858 \\
\text { 1. } 5793\end{array}$ & $\begin{array}{r}100 \\
52 \\
10 \\
28\end{array}$ & $\begin{array}{l}1.4395 \\
1.4221 \\
1.4127 \\
1.3902 \\
1.3824\end{array}$ & $\begin{array}{l}10 \\
10 \\
10 \\
10 \\
10\end{array}$ \\
\hline $\begin{array}{l}1.6345 \\
1.6148 \\
1.6055 \\
1.5494 \\
1.5253\end{array}$ & $\begin{array}{r}25 \\
23 \\
8 \\
31 \\
11\end{array}$ & $\begin{array}{l}\text { 1. } 5167 \\
1.4933 \\
\text { 1. } 4890 \\
\text { 1. } 4839 \\
1.4447\end{array}$ & $\begin{array}{l}24 \\
\\
10 \\
10 \\
49 \\
54\end{array}$ & $\begin{array}{l}\text { 1. } 3442 \\
\text { 1. } 3180 \\
\text { 1. } 2514\end{array}$ & $\begin{array}{l}10 \\
11 \\
11\end{array}$ \\
\hline $\begin{array}{l}1.5217 \\
1.5176 \\
1.5158 \\
1.4784 \\
1.4756\end{array}$ & $\begin{array}{l}11 \\
24 \\
32 \\
26 \\
39\end{array}$ & $\begin{array}{l}\text { 1. } 4328 \\
\text { 1. } 4281 \\
\text { 1. } 4158\end{array}$ & $\begin{array}{l}11 \\
24 \\
42 \\
48\end{array}$ & & \\
\hline $\begin{array}{l}1.4592 \\
1.4551 \\
1.4491 \\
1.4265 \\
1.3937\end{array}$ & $\begin{array}{l}14 \\
15 \\
30 \\
42 \\
14\end{array}$ & $\begin{array}{l}\text { 1. } 3640 \\
\text { 1. } 3496 \\
\text { 1. } 3466\end{array}$ & $\begin{array}{r}48 \\
9 \\
11 \\
11\end{array}$ & & \\
\hline $\begin{array}{l}\text { 1. } 3816 \\
\text { 1. } 3558 \\
\text { 1. } 3310\end{array}$ & $\begin{array}{r}9 \\
14 \\
8\end{array}$ & $\begin{array}{l}\text { 1. } 3267 \\
\text { 1. } 3048\end{array}$ & $\begin{array}{l}13 \\
18\end{array}$ & & \\
\hline
\end{tabular}

1 Interplanar spacing.

2 Relative intensity.

$50 \mathrm{Ga}_{2} \mathrm{O}_{3}, 37.5 \mathrm{Sc}_{2} \mathrm{O}_{3}: 62.5 \mathrm{Ga}_{2} \mathrm{O}_{3}$, and $75 \mathrm{Sc}_{2} \mathrm{O}_{3}: 25 \mathrm{Cr}_{2} \mathrm{O}_{3}$, could not be indexed although they, too, appear similar to the pattern of kappa alumina. It would seem, strictly by the comparison of X-ray patterns, that $\mathrm{In}_{2} \mathrm{O}_{3}-\mathrm{Ga}_{2} \mathrm{O}_{3}$ and $\mathrm{Sc}_{2} \mathrm{O}_{3}-\mathrm{Ga}_{2} \mathrm{O}_{3}$ phases are isostructural with each other, but not necessarily with kappa alumina. The phase most dissimilar with kappa alumina in this entire group is that of $75 \mathrm{Sc}_{2} \mathrm{O}_{3}: 25 \mathrm{Cr}_{2} \mathrm{O}_{3}$.

\subsection{Other Structure Types}

Keith and Roy [3] reported that an unknown phase occurs in a melted 50:50 mixture of $\operatorname{In}_{2} \mathrm{O}_{3}$ and $\mathrm{Al}_{2} \mathrm{O}_{3}$. They designated this phase as a high form of $\mathrm{In}_{2} \mathrm{O}_{3}$ : $\mathrm{Al}_{2} \mathrm{O}_{3}$ and listed several of its X-ray reflections. In an effort to obtain this phase, the experiment of Keith and Roy was repeated. The melted specimen of $50: 50 \quad \mathrm{In}_{2} \mathrm{O}_{3}-\mathrm{Al}_{2} \mathrm{O}_{3}$ contained two phases, $\operatorname{In}_{2} \mathrm{O}_{3}$ and apparently the same phase as reported by Keith and Roy. Other experiments with the $50 \operatorname{In}_{2} \mathrm{O}_{3}$ :
TABLE 4. X-ray powder diffraction data for $(1-x) \mathrm{Se}_{2} \mathrm{O}_{3} \cdot x \mathrm{Al}_{2} \mathrm{O}_{3}$ s $\left(50 \mathrm{Sc}_{2} \mathrm{O}_{3}: 50 \mathrm{Al}_{2} \mathrm{O}_{3}\right.$ mixture)

\begin{tabular}{|c|c|c|c|c|}
\hline$\underset{h k l^{1}}{\text { Rhom. }}$ & $d^{2}$ & $I^{3}$ & $\frac{1}{d^{2}} \mathrm{obs}$ & $\frac{1}{d^{2}} \mathrm{cal}$ \\
\hline & $A$ & & $A^{-2}$ & $A^{-2}$ \\
\hline 222 & 2. 842 & 29 & 0.1238 & 0.1238 \\
\hline $\begin{array}{l}22 \overline{2} \\
040\end{array}$ & $\begin{array}{l}\text { 2. } 687 \\
\text { 2. } 359\end{array}$ & $\begin{array}{r}100 \\
21\end{array}$ & $\begin{array}{l}.1385 \\
.1797\end{array}$ & $\begin{array}{r}.1385 \\
.1798\end{array}$ \\
\hline $04 \overline{1} / 2 \overline{3} 2$ & 2.265 & 5 & .1940 & .1948 \\
\hline $\begin{array}{l}22 \overline{3} \\
240 \\
332\end{array}$ & $\begin{array}{l}2.241 \\
2.138 \\
2.004\end{array}$ & $\begin{array}{l}5 \\
7 \\
9\end{array}$ & $\begin{array}{l}1991 \\
.2185 \\
.2491\end{array}$ & $\begin{array}{l}1984 \\
.2174 \\
.2500\end{array}$ \\
\hline $04 \overline{3}$ & 1. 8496 & 5 & .2923 & .2920 \\
\hline $15 \overline{2}$ & 1. 7051 & 21 & .3440 & .3436 \\
\hline $04 \overline{4}$ & 1. 6350 & 28 & .3741 & .3741 \\
\hline $26 \overline{2}$ & 1. 4180 & 12 & .4973 & .4979 \\
\hline$\overline{2} 6 \overline{2}$ & 1. 3990 & 5 & .5123 & .5130 \\
\hline
\end{tabular}

1 Rhombohedral cell, $a=9.45 \mathrm{~A}, \alpha=87.4^{\circ}$

Hexagonal cell, $a=13.07 \mathrm{~A}, c=17.05 \mathrm{~A}$.

2 Interplanar spacing.

${ }^{3}$ Relative intensity.

$50 \mathrm{Al}_{2} \mathrm{O}_{3}$ mixture indicated that the unknown phase is probably metastable in the $\operatorname{In}_{2} \mathrm{O}_{3}-\mathrm{Al}_{2} \mathrm{O}_{3}$ system and occurs only on quenching the melt.

In the $\mathrm{Sc}_{2} \mathrm{O}_{3}-\mathrm{Al}_{2} \mathrm{O}_{3}$ system a stable phase occurs which, according to X-ray powder data, appears to be isostructural with the metastable phase of the $\mathrm{In}_{2} \mathrm{O}_{3}-\mathrm{Al}_{2} \mathrm{O}_{3}$ system. This phase occurs over a region of $\mathrm{Sc}_{2} \mathrm{O}_{3}-\mathrm{Al}_{2} \mathrm{O}_{3}$ compositions and represents a solid solution and not a true compound. The X-ray pattern of the $50 \mathrm{Sc}_{2} \mathrm{O}_{3}: 50 \mathrm{Al}_{2} \mathrm{O}_{3}$ mixture is given in table 4. The pattern was indexed on the basis of a rhombohedral cell by comparison with the pattern of $2 \mathrm{PbO} \cdot \mathrm{Nb}_{2} \mathrm{O}_{5}$, a rhombohedral distortion of the pvrochlore structure. The X-ray pattern for the $\mathrm{Sc}_{2} \mathrm{O}_{3}-\mathrm{Al}_{2} \mathrm{O}_{3}$ phase was diffuse regardless of heat treatment of the specimen, and therefore the agreement between observed and calculated values, given in table 4 , is only fair for the less intense reflections. Single crystal data is needed to ascertain the correct structure type. Superstructure peaks, necessary to differentiate a body centered C-type structure or a face centered pyrochlore structure from the fluorite or $\mathrm{Sb}_{2} \mathrm{O}_{3}$-type structures, could not be found in the X-ray pattern. The fluorite structure would require that all the oxygen vacancies be disordered. For the $\mathrm{Sc}_{2} \mathrm{O}_{3} \cdot \mathrm{Al}_{2} \mathrm{O}_{3}$ phase to have a C-type or a $\mathrm{Sb}_{2} \mathrm{O}_{3}$ type structure a complete ordering of the vacant oxygen sites would be required while the pyrochlore structure would necessitate only partial ordering.

A number of different phases encountered in this investigation have not been identified or even related with a specific known structure type. These phases, apparently all compounds, exist in various systems at either the $3: 1,2: 1$ or $1: 1$ molar compositions.

The $3: 1$ compounds occur exclusively in galliate systems; specifically, $\mathrm{Ga}_{2} \mathrm{O}_{3}$ with either $\mathrm{Sm}_{2} \mathrm{O}_{3}, \mathrm{Eu}_{2} \mathrm{O}_{3}$, $\mathrm{Gd}_{2} \mathrm{O}_{3}, \mathrm{Dy}_{2} \mathrm{O}_{3}, \mathrm{Ho}_{2} \mathrm{O}_{3}, \mathrm{Y}_{2} \mathrm{O}_{3}$, or $\mathrm{Er}_{2} \mathrm{O}_{3}$. These compounds, all apparently isostructural, have not been previously reported. The X-ray data of $3 \mathrm{Gd}_{2} \mathrm{O}_{3}$. $\mathrm{Ga}_{2} \mathrm{O}_{3}$, which is given in table 5 , is typical of all the patterns of these isostructural 3:1 compounds. The only 
difference between the various patterns is the appropriate shift in the $d$-spacings of the $\mathrm{X}$-ray reflections due to cation size differences. It is noteworthy that the 3:1 compound does not occur in systems in which a perovskite type compound forms as a stable phase.

A series of apparently isostructural 2:1 compounds exist in both aluminate and galliate systems. The first 2:1 compound of this type studied extensively was the $2 \mathrm{Y}_{2} \mathrm{O}_{3} \cdot \mathrm{Al}_{2} \mathrm{O}_{3}$ phase [22]. In binary aluminate systems, $\mathrm{Gd}^{+3}, \mathrm{Dy}^{+3}, \mathrm{Ho}^{+3}, \mathrm{Er}^{+3}, \mathrm{Tm}^{+3}$, and $\mathrm{Yb}^{+3}$ can be substituted for $\mathrm{Y}^{+3}$. In galliate systems, however, only the oxides of the larger cations $\mathrm{La}^{+3}, \mathrm{Nd}^{+3}, \mathrm{Sm}^{+3}$, and $\mathrm{Eu}^{+3}$ form 2:1 compounds with $\mathrm{Ga}_{2} \mathrm{O}_{3}$. Evidently this structure type is dependent on radius ratios and will only occur within specific ranges of cation radii values. An example of this occurs in the $\mathrm{Yb}_{2} \mathrm{O}_{3}$ $\mathrm{Al}_{2} \mathrm{O}_{3}$ and $\mathrm{Lu}_{2} \mathrm{O}_{3}-\mathrm{Al}_{2} \mathrm{O}_{3}$ systems. The $2: 1$ compound forms in the $\mathrm{Yb}_{2} \mathrm{O}_{3}-\mathrm{Al}_{2} \mathrm{O}_{3}$ system but not in the $\mathrm{Lu}_{2} \mathrm{O}_{3}-\mathrm{Al}_{2} \mathrm{O}_{3}$ system, even though the radius of $\mathrm{Lu}^{+3}$ is only $0.01 \mathrm{~A}$ smaller than that of $\mathrm{Yb}^{+3}$. However, the X-ray pattern of the $3: 5$ mixture in the $\mathrm{Lu}_{2} \mathrm{O}_{3}-\mathrm{Al}_{2} \mathrm{O}_{3}$ system showed, in addition to the garnet peaks, a few minor reflections which may represent a $2: 1$ phase. At present, it would appear that the occurrence of a 2:1 compound in the $\mathrm{Lu}_{2} \mathrm{O}_{3}-\mathrm{Al}_{2} \mathrm{O}_{3}$ system is strictly a metastable phenomenon.

Table 6 compares the X-ray pattern for $2 \mathrm{Y}_{2} \mathrm{O}_{3}$. $\mathrm{Al}_{2} \mathrm{O}_{3}$ obtained in this investigation with that reported by Warshaw and Roy [22]. They described this $2: 1$ phase as being distorted cubic with a primitive lattice. Because of certain line splitting in the X-ray pattern, they infer that the material may actually have rhombohedral symmetry. The two patterns given in table 6 are very similar and obviously represent the same phase; neither pattern could be indexed in the present work. It is evident, from
TABLE 5. X-ray powder diffraction data for $3 \mathrm{Gd}_{2} \mathrm{O}_{3} \cdot \mathrm{Ga}_{2} \mathrm{O}$

\begin{tabular}{c|r||c|c}
\hline \hline$d^{1}$ & $I^{2}$ & $d^{1}$ & $I^{2}$ \\
\cline { 1 - 2 } & & & \\
\cline { 1 - 2 } 4.53 & 20 & 2.005 & 30 \\
4.11 & 13 & 1.9918 & 15 \\
3.204 & 14 & 1.9027 & 15 \\
3.054 & 100 & 1.8349 & 32 \\
3.025 & 57 & 1.8097 & 14 \\
2.990 & 27 & 1.7672 & 17 \\
2.908 & 22 & 1.7184 & 17 \\
2.824 & 29 & 1.6808 & 17 \\
2.630 & 17 & 1.6450 & 24 \\
2.301 & 15 & 1.5788 & 24 \\
2.241 & 17 & 1.5456 & 17 \\
2.199 & 13 & 1.5276 & 25 \\
2.032 & 39 & & \\
\hline
\end{tabular}

1 Interplanar spacing

2 Relative intensity.

the present $\mathrm{X}$-ray data, that $2 \mathrm{Y}_{2} \mathrm{O}_{3} \cdot \mathrm{Al}_{2} \mathrm{O}_{3}$ has low symmetry and cannot be designated as cubic or rhombohedral.

The only $\mathrm{A}^{+3} \mathrm{~B}^{+3} \mathrm{O}_{3}$ type compounds found in the present investigation which do not have the perovskite structure are those which occur in the $\mathrm{Eu}_{2} \mathrm{O}_{3}$ $\mathrm{In}_{2} \mathrm{O}_{3}, \mathrm{Gd}_{2} \mathrm{O}_{3}-\mathrm{In}_{2} \mathrm{O}_{3}$, and $\mathrm{Dy}_{2} \mathrm{O}_{3}-\mathrm{In}_{2} \mathrm{O}_{3}$ systems (designated as I in fig. 1). These $1: 1$ compounds will be reported on more extensively in a following publication [23]. The $\mathrm{Eu}_{2} \mathrm{O}_{3} \cdot \operatorname{In}_{2} \mathrm{O}_{3}, \mathrm{Gd}_{2} \mathrm{O}_{3} \cdot \mathrm{In}_{2} \mathrm{O}_{3}$, and $\mathrm{Dy}_{2} \mathrm{O}_{3}$. $\mathrm{In}_{2} \mathrm{O}_{3}$ compounds appear to be isostructural, having pseudohexagonal symmetry. The $\mathrm{Dy}_{2} \mathrm{O}_{3} \cdot \operatorname{In}_{2} \mathrm{O}_{3}$ compound apparently decomposes between $1600{ }^{\circ} \mathrm{C}$ and $1650{ }^{\circ} \mathrm{C}$ to a mixture of $\mathrm{B}$ - and $\mathrm{C}$-rare earth oxide structure types.

\subsection{Subsolidus Phase Equilibria Relationships}

Figure 5 gives the subsolidus phase equilibria relationships for various binary combinations of oxides of the trivalent cations. The figure is divided into

TABLE 6. X-ray powder diffraction data for $2 \mathrm{Y}_{2} \mathrm{O}_{3} \cdot \mathrm{Al}_{2} \mathrm{O}_{3}$

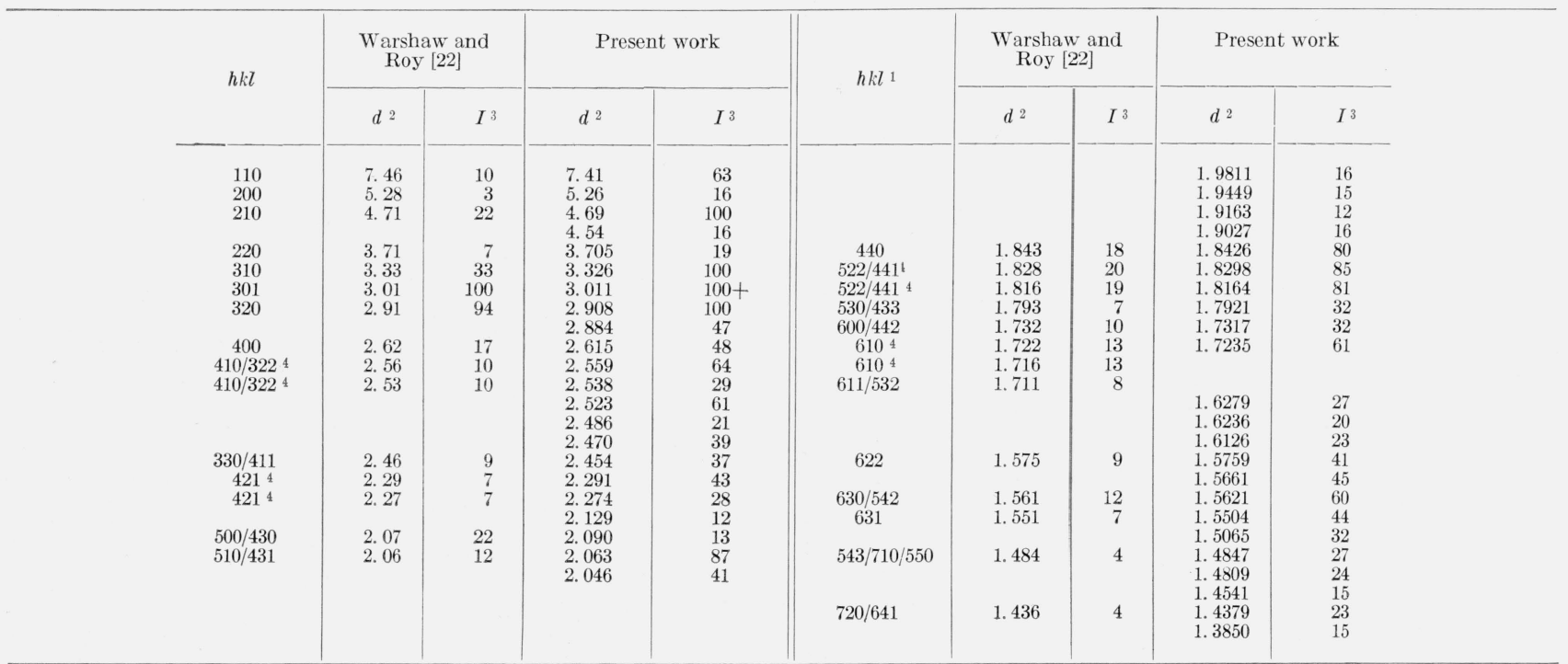

1 Based on cubic cell with $a=10.40 \mathrm{~A}$ [22].

2 Interplanar spacing.

4 "Splitting may represent a possible rhombohedral distortion of the cubic lattice" [22]. 
six groups of diagrams, each having either $\mathrm{Al}_{2} \mathrm{O}_{3}$, $\mathrm{Ga}_{2} \mathrm{O}_{3}, \mathrm{Cr}_{2} \mathrm{O}_{3}, \mathrm{Fe}_{2} \mathrm{O}_{3}, \mathrm{Se}_{2} \mathrm{O}_{3}$, or $\mathrm{In}_{2} \mathrm{O}_{3}$ as one component. Previously published diagrams pertinent to a given series are not reproduced here but are included as literature references in the legend of the figure.

All the diagrams were drawn primarily from the data contained in table 1 . Data points are indicated by circles on the diagrams. In some instances entire diagrams, or portions thereof, were estimated from the phase relations of similar known systems. The boundaries of the garnet solid solutions were determined by the parametric method while the solid solution areas of A-, B-, or C-type phases were established by a variation of this method as previously described [1]. The boundaries of most of the other type solid solution areas were approximated from X-ray patterns on the basis of the relative amounts of each phase present in a specimen containing two phases. Possible variations of solid solubility with temperature have been ignored in this work. In general, the diagrams must be considered as approximate and minor shifts in solid solution boundary limits may be expected.

The subsolidus phase diagram for the $\mathrm{Y}_{2} \mathrm{O}_{3}-\mathrm{Al}_{2} \mathrm{O}_{3}$ system has been included in figure $5 \mathrm{a}$ although the diagram has been previously published by Warshaw and Roy [22]. The present diagram differs from the previous one in that a $1: 1$ perovskite type compound is shown to have a region of stability at elevated temperatures. At lower temperatures, the compound apparently decomposes to a mixture of $2 \mathrm{Y}_{2} \mathrm{O}_{3} \cdot \mathrm{Al}_{2} \mathrm{O}_{3}$ and $3 \mathrm{Y}_{2} \mathrm{O}_{3} \cdot 5 \mathrm{Al}_{2} \mathrm{O}_{3}$. The present work does not contradict the published data, but merely extends to temperature ranges not previously reported. A complete reinvestigation of this system is now being undertaken. Because the stability of the 1:1 compound in the $\mathrm{Y}_{2} \mathrm{O}_{3}-\mathrm{Al}_{2} \mathrm{O}_{3}$ system is still unknown, the stability of the perovskite phase in the related systems of $\mathrm{Ho}_{2} \mathrm{O}_{3}-\mathrm{Al}_{2} \mathrm{O}_{3}$ and $\mathrm{Er}_{2} \mathrm{O}_{3}-\mathrm{Al}_{2} \mathrm{O}_{3}$ is also in doubt.

Perhaps one of the more interesting systems investigated is that of $\mathrm{Dy}_{2} \mathrm{O}_{3}-\mathrm{In}_{2} \mathrm{O}_{3}$, figure $5 \mathrm{f}$. The phase diagram of this system indicates a solid solution area of B-type rare earth oxide. Since $\mathrm{Dy}_{2} \mathrm{O}_{3}$ and $\mathrm{In}_{2} \mathrm{O}_{3}$ both have the C-type structure, it is unusual for a B-type structure to occur. The largest average cation radius of the B-type solid solution in the $\mathrm{Dy}_{2} \mathrm{O}_{3}-\mathrm{In}_{2} \mathrm{O}_{3}$ system is about $0.87 \mathrm{~A}$. This value is appreciably smaller than the radius of $\mathrm{Gd}^{+3}$ $(0.97 \mathrm{~A})$ which is the smallest rare earth ion to form a pure B-type oxide. Goldschmidt et al. [24] reported that $\mathrm{Dy}_{2} \mathrm{O}_{3}$ formed a B-type structure at elevated temperatures but his work has not yet been confirmed [9]. The formation of the solid solution area of $\mathrm{B}$-type in the $\mathrm{Dy}_{2} \mathrm{O}_{3}-\mathrm{In}_{2} \mathrm{O}_{3}$ system might actually indicate that $\mathrm{Dy}_{2} \mathrm{O}_{3}$ does transform from Cto B-type in the pure state. Specimens of $\mathrm{Dy}_{2} \mathrm{O}_{3}$ heated above the melting point of platinum shattered in a manner indicative of a possible reversible phase transformation.

\section{Summary}

A survey was made of the subsolidus reactions that occur in various binary systems involving oxides of the trivalent cations. Incorporated into the study were $\mathrm{Al}_{2} \mathrm{O}_{3}, \mathrm{Ga}_{2} \mathrm{O}_{3}, \mathrm{Cr}_{2} \mathrm{O}_{3}, \mathrm{Fe}_{2} \mathrm{O}_{3}, \mathrm{Sc}_{2} \mathrm{O}_{3}$, $\mathrm{In}_{2} \mathrm{O}_{3}, \mathrm{Y}_{2} \mathrm{O}_{3}$, and most of the trivalent rare earth oxides. Mixtures in 69 different binary systems were investigated. Specimens were heated at various temperatures until equilibrium was attained and then examined at room temperature by X-ray powder diffraction techniques.

According to the radii of constituent cations, a classification was made of the structure types of the various phases found for equimolar mixtures. The classification consists of a plot of the radii of $\mathrm{A}^{+3}$ cations versus the radii of $\mathrm{B}^{+3}$ cations and shows specific regions of stability for the different structure types. The graph is divided into regions of one and two phase areas and represents, in addition to several unknown types, the following structures: A-, B-, and C-type rare earth oxide; corundum; beta gallia; kappa alumina; garnet; and perovskite. The classification essentially summarizes the structure types found in all possible binary mixtures of oxides of the trivalent cations studied.

With one exception, all the $\mathrm{A}^{+3} \mathrm{~B}^{+3} \mathrm{O}_{3}$ type compounds which occur have the perovskite structure. The minimum tolerance factors of the alumina and gallia series of perovskite compounds are significantly larger than the $\mathrm{Cr}_{2} \mathrm{O}_{3}, \mathrm{Fe}_{2} \mathrm{O}_{3}, \mathrm{Sc}_{2} \mathrm{O}_{3}$, and $\mathrm{In}_{2} \mathrm{O}_{3}$ series. The appreciable difference in minimum tolerance factor apparently can be related to the effect of partial covalent bonding.

Appreciable solid solution of the garnet type compounds occurs in binary systems containing $\mathrm{Ga}_{2} \mathrm{O}_{3}$. The range of solid solution generally increases to a maximum at about $\mathrm{Tm}^{+3}$ as the radii of the rare earth cation decreases. Solid solution of the garnet compound does not occur in binary systems containing a stable perovskite phase.

Based on the similarity of X-ray patterns, the structure of kappa alumina appears to be related to the structures of $(1-x) \mathrm{Fe}_{2} \mathrm{O}_{3} \cdot x \mathrm{Al}_{2} \mathrm{O}_{3}$ ss and $(1-x)$ $\mathrm{Fe}_{2} \mathrm{O}_{3} \cdot x \mathrm{Ga}_{2} \mathrm{O}_{3}$ ss. There is also a similarity between these phases and other solid solution phases which occur in the $\mathrm{In}_{2} \mathrm{O}_{3}-\mathrm{Ga}_{2} \mathrm{O}_{3}, \mathrm{Sc}_{2} \mathrm{O}_{3}-\mathrm{Ga}_{2} \mathrm{O}_{3}$, and $\mathrm{Sc}_{2} \mathrm{O}_{3}$ $\mathrm{Cr}_{2} \mathrm{O}_{3}$ systems.

A 2:1 compound occurs in a number of those systems containing either $\mathrm{Al}_{2} \mathrm{O}_{3}$ or $\mathrm{Ga}_{2} \mathrm{O}_{3}$ as one component. A 3:1 compound occurs exclusively in systems containing $\mathrm{Ga}_{2} \mathrm{O}_{3}$. The structures of the $2: 1$ and $3: 1$ compounds were not related to any known structure type. A rhombohedral phase which occurs stably in the $\mathrm{Sc}_{2} \mathrm{O}_{3}-\mathrm{Al}_{2} \mathrm{O}_{3}$ system and metastably in the $\mathrm{In}_{2} \mathrm{O}_{3}-\mathrm{Al}_{2} \mathrm{O}_{3}$ system may have either a fluorite, $\mathrm{Sb}_{2} \mathrm{O}_{3}$, pyrochlore, or C-type structure.

The subsolidus phase assemblages for 79 binary systems were predicted from the data compiled in this investigation. 
TABLE 1.-Binary oxide mixtures of the trivalent cations

$\mathbf{A l}^{+3}$ and larger cations

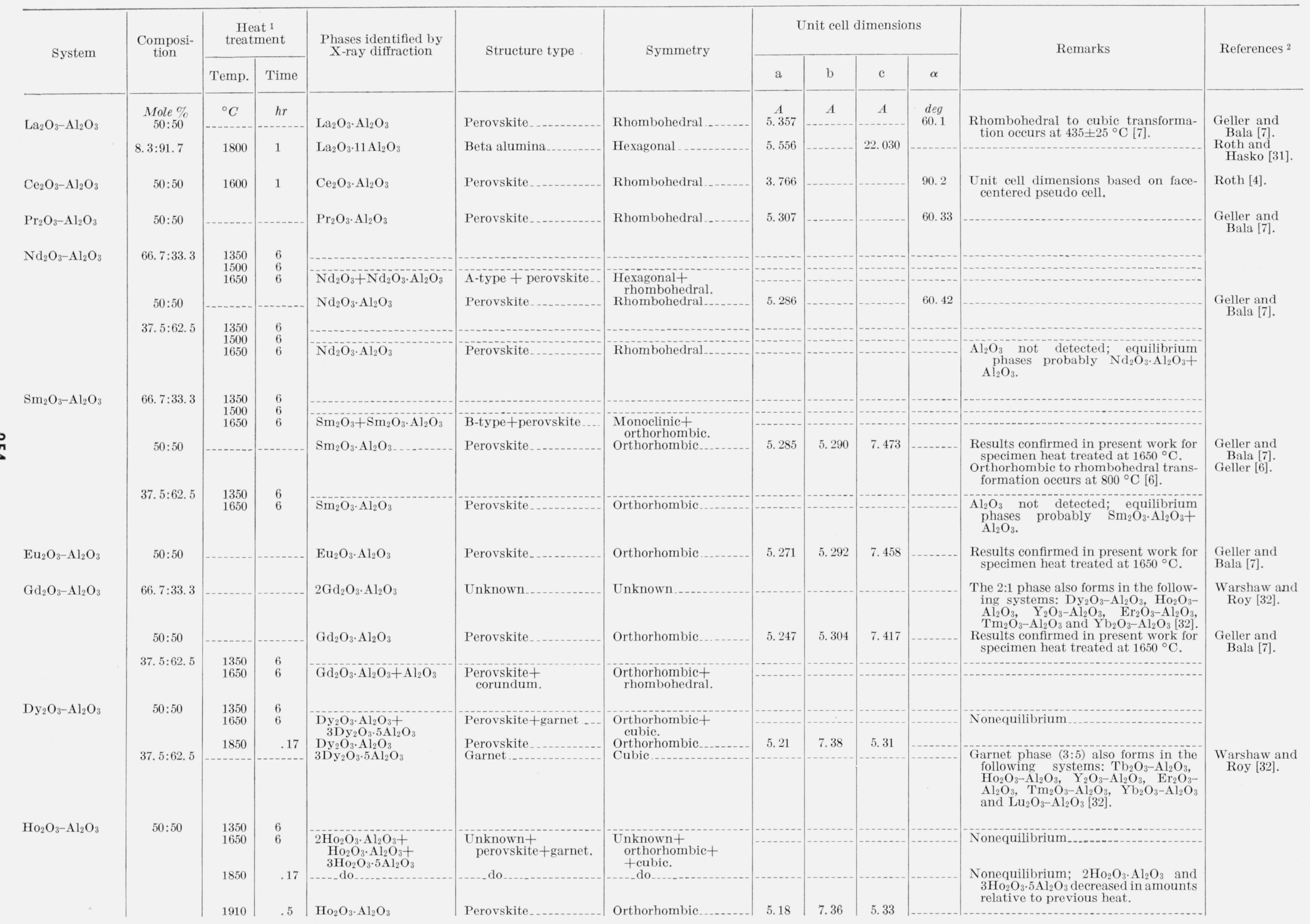




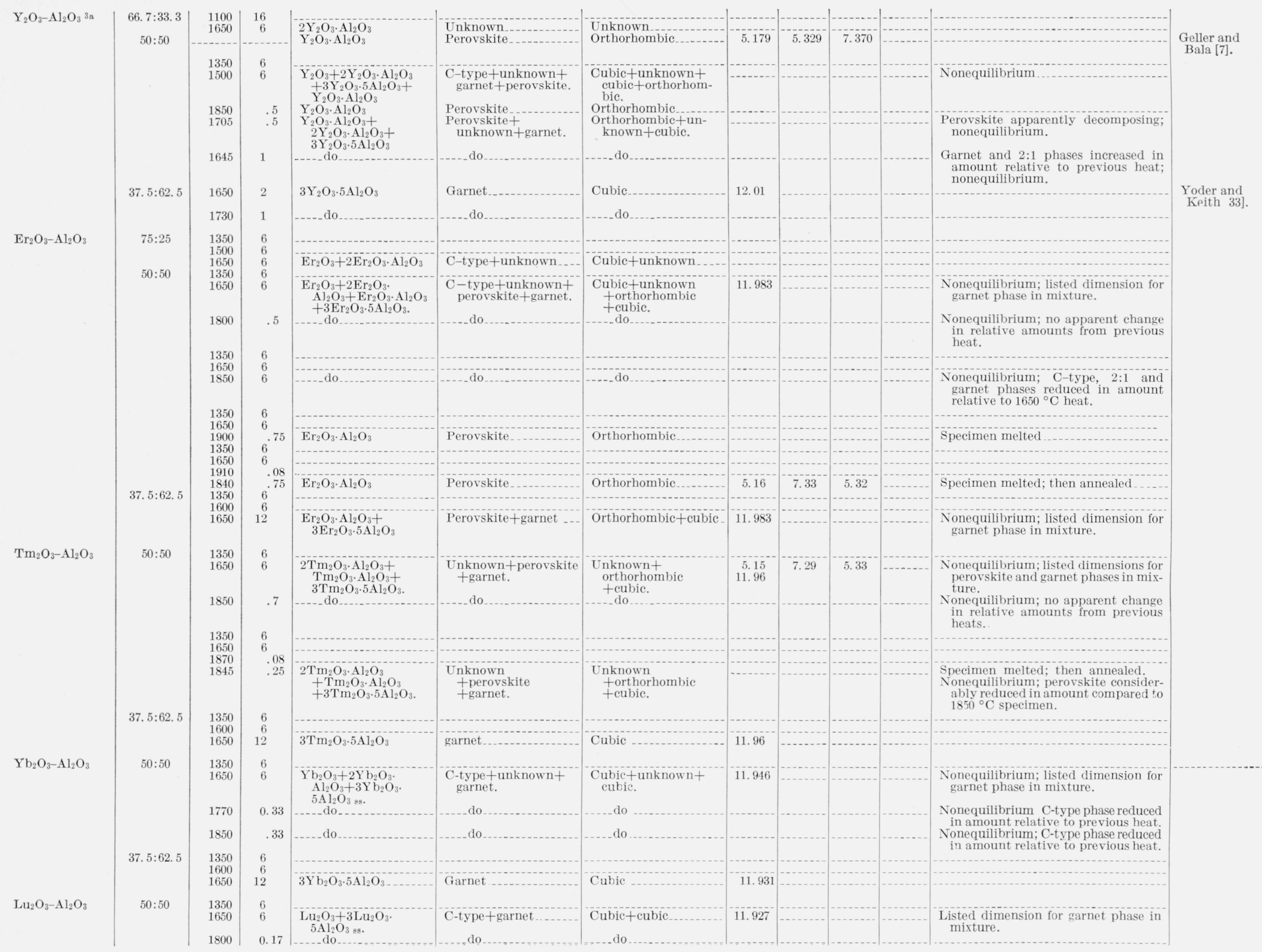

See footnotes at end of table, 
TABLE 1.-Binary oxide mixtures of the trivalent cations-Continued

$\mathrm{Al}^{+3}$ and larger cations - Continued

\begin{tabular}{|c|c|c|c|c|c|c|c|c|c|c|c|c|}
\hline \multirow{2}{*}{ System } & \multirow{2}{*}{$\begin{array}{l}\text { Composi- } \\
\text { tion }\end{array}$} & \multicolumn{2}{|c|}{$\begin{array}{l}\text { Heat } 1 \\
\text { treatment }\end{array}$} & \multirow{2}{*}{$\begin{array}{l}\text { Phases identified by } \\
\text { X-ray diffraction }\end{array}$} & \multirow{2}{*}{ Structure type } & \multirow{2}{*}{ Symmetry } & \multicolumn{4}{|c|}{ Unit cell dimensions } & \multirow{2}{*}{ Remarks } & \multirow{2}{*}{ References ${ }^{2}$} \\
\hline & & Temp. & Time & & & & a & b & c & $\alpha$ & & \\
\hline \multirow{7}{*}{$\mathrm{In}_{2} \mathrm{O}_{3}-\mathrm{Al}_{2} \mathrm{O}_{3}$} & \multirow[t]{2}{*}{$\begin{array}{l}\text { Mole } \% \\
37.5: 62.7\end{array}$} & ${ }^{\circ} \mathrm{C}$ & \multirow{2}{*}{$\begin{array}{l}h r \\
6 \\
6 \\
6\end{array}$} & & & & $A$ & $A$ & $A$ & deg & & \\
\hline & & $\begin{array}{l}1600 \\
1650\end{array}$ & & $3 \mathrm{Lu}_{2} \mathrm{O}_{3} .5 \mathrm{Al}_{2} \mathrm{O}_{3} \ldots$ & \multirow{2}{*}{ Garnet } & \multirow{2}{*}{ Cubic } & \multirow[t]{2}{*}{11.912} & & & & \multirow{2}{*}{ May be some $2: 1$ phase present. } & \\
\hline & $50: 50$ & 800 & 20 & & & & & & & & & \\
\hline & & $\begin{array}{l}1350 \\
1500\end{array}$ & $\begin{array}{r}6 \\
46\end{array}$ & $\mathrm{In}_{2} \mathrm{O}_{3 \mathrm{s8}}+\mathrm{Al}_{2} \mathrm{O}_{3 \ldots-}$ & C-type+corundum & Cubic+rhombohedral & $\mathrm{x}^{2}$ & 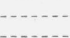 & & & & \\
\hline & & $\begin{array}{r}1650 \\
800\end{array}$ & $\begin{array}{l}42 \\
20\end{array}$ & do d & - & -do & & $\cdots$ & & & & \\
\hline & & 1350 & 6 & & & & & & & & & \\
\hline & & 1700 & 0.0 & $\mathrm{~m}_{2} \mathrm{O}_{3}$ в8 + unknown.... & C-type+unknown.... & Cubic+unknown ..... & & $\cdots$ & -. & & $\begin{array}{l}\text { Specimen melted, unidentified phase } \\
\text { appears to be isostructural with } \\
\text { rhombohedral phase of } \mathrm{S}_{2} \mathrm{O}_{3}-\mathrm{Al}_{2} \mathrm{O}_{3} \\
\text { system. This phase similar to un- } \\
\text { known phase previously reported by } \\
\text { Keith and Roy [3]. }\end{array}$ & \\
\hline \multirow[t]{4}{*}{$\mathrm{Se}_{2} \mathrm{O}_{3}-\mathrm{Al}_{2} \mathrm{O}_{3}$} & $66.7: 33.3$ & $\begin{array}{l}1350 \\
1650\end{array}$ & \multirow[t]{2}{*}{$\begin{array}{l}6 \\
6\end{array}$} & $\mathrm{Sc}_{2} \mathrm{O}_{3} 8 \mathrm{~s}+(1-x) \mathrm{Sc}_{2} \mathrm{O}_{3}$ & C-type + unknown .... & Cubic+rhombohedral & & & & & & \\
\hline & \multirow[t]{3}{*}{$50: 50$} & 1350 & & $x \mathrm{Al}_{2} \mathrm{O}_{3}$ ss. & & & & & & & & \\
\hline & & 1650 & 9.5 & $(1-x) \mathrm{Sc}_{2} \mathrm{O}_{3} \cdot x \mathrm{Al}_{2} \mathrm{O}_{3}$ sв- & Unknown & Rhombohedral & 9.45 & & & 87.4 & $\begin{array}{l}\text { Structure type appears to be rhombo- } \\
\text { hedral distortion of fluorite type; see } \\
\text { text. }\end{array}$ & \\
\hline & & $\begin{array}{l}1790 \\
1960\end{array}$ & $\begin{array}{r}0.08 \\
.08\end{array}$ & - do & do & 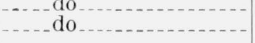 & & & & & \multirow[t]{2}{*}{ Specimen melted ... } & \\
\hline \multirow[t]{7}{*}{$\mathrm{Fe}_{2} \mathrm{O}_{3}-\mathrm{Al}_{2} \mathrm{O}_{3}{ }^{3 \mathrm{~b}}$} & \multirow[t]{2}{*}{$53: 47$} & 800 & 20 & & & & & & & & & \\
\hline & & 1375 & $\begin{array}{l}00 \\
49\end{array}$ & $(1-x) \mathrm{Fe}_{2} \mathrm{O}_{3} \cdot x \mathrm{Al}_{2} \mathrm{O}_{3} s \mathrm{~s}$ & Kappa alumina & Orthorhombic & & & & & & \\
\hline & \multirow[t]{3}{*}{$50: 50$} & $\begin{array}{r}800 \\
1000\end{array}$ & $\begin{array}{l}20 \\
65\end{array}$ & & & & & & & & & \\
\hline & & 1350 & ${ }^{4} 6$ & $(1-x) \mathrm{Fe}_{2} \mathrm{O}_{3} \cdot x \mathrm{Al}_{2} \mathrm{O}_{3}$ & Kappa alumina & Orthorhombic & & & & & & \\
\hline & & 1450 & & $(1-\mathrm{x}) \mathrm{Fe}_{2} \mathrm{O}_{3} \cdot x \mathrm{Al}_{2} \mathrm{O}_{3}$ s - & Kappa alumina - & Orthorhombic & 7.03 & 6.33 & 7.411 & & $\begin{array}{l}\text { This cell apparently not correct; see } \\
\text { text. }\end{array}$ & $\begin{array}{l}\text { Richardson, } \\
\text { Ball and } \\
\text { Rigby [20]. }\end{array}$ \\
\hline & \multirow{2}{*}{$47: 53$} & 1000 & 65 & & & & & & & & & \\
\hline & & 1350 & ${ }^{4} 6$ & $(1-x) \mathrm{Fe}_{2} \mathrm{O}_{3} \cdot x \mathrm{~A}_{2} \mathrm{O}_{3}$ s & Kappa alumina... & Orthorhombic_......- & 8. 59 & 9.23 & 4.98 & & & \\
\hline $\mathrm{Cr}_{2} \mathrm{O}_{3}-\mathrm{Al}_{2} \mathrm{O}_{3}{ }^{3 \mathrm{e}}$ & $50: 50$ & $\begin{array}{l}1000 \\
1600\end{array}$ & $\begin{array}{l}6 \\
6\end{array}$ & $(1-x) \mathrm{Cr}_{2} \mathrm{O}_{3} \cdot x \mathrm{Al}_{2} \mathrm{O}_{38-}$ & Corundum... & Rhombohedral & & & & & & \\
\hline \multirow{3}{*}{$\mathrm{Ga}_{2} \mathrm{O}_{3}-\mathrm{Al}_{2} \mathrm{O}_{3}{ }^{4 \mathrm{~d}}$} & \multirow{3}{*}{$\begin{array}{l}50: 50 \\
30: 70\end{array}$} & 1350 & 6 & & & & & & & & & \\
\hline & & 1650 & 6 & $\mathrm{Ga}_{2} \mathrm{O}_{3} \mathrm{~s}$ & Beta gallia_... & Monoclinic & & & & & & \\
\hline & & 1650 & 6 & $\mathrm{Ga}_{2} \mathrm{O}_{38 \mathrm{~s}}+\mathrm{Al}_{2} \mathrm{O}_{38 s}$ & $\begin{array}{l}\text { Beta gallia+ Cor- } \\
\text { undum. }\end{array}$ & $\begin{array}{l}\text { Monoclinic +rhombo- } \\
\text { hedral. }\end{array}$ & & & & & & \\
\hline
\end{tabular}

\section{$\mathrm{Ga}^{+3}$ and larger cations}

\begin{tabular}{|c|c|c|c|c|c|c|c|c|c|c|c|c|}
\hline \multirow[t]{4}{*}{$\mathrm{La}_{2} \mathrm{O}_{3}-\mathrm{Ga}_{2} \mathrm{O}_{3}$} & $66.7: 33.3$ & $\begin{array}{l}1350 \\
1500\end{array}$ & $\begin{array}{r}6 \\
4 \\
4\end{array}$ & $2 \mathrm{La}_{2} \mathrm{O}_{3} \cdot \mathrm{Ga}_{2} \mathrm{O}_{3-}$ & Unknown. & Unknown ..... & & & & & oe small amount of peroyskite & \multirow{4}{*}{ Geller [6]. } \\
\hline & $50: 50$ & & & $\mathrm{La}_{2} \mathrm{O}_{3} \cdot \mathrm{Ga}_{2} \mathrm{O}_{3-}$ & Perovskite_. & Orthorhombic. & 5. 496 & 5,524 & 7.787 & & $\begin{array}{l}\text { type compound present. } \\
\text { Orthorhombic to rhombohed }\end{array}$ & \\
\hline & \multirow{2}{*}{ 8. $2: 91.8$} & 1000 & \multirow{2}{*}{$\begin{array}{r}20 \\
6\end{array}$} & & & & & & & & formation occurs at $875^{\circ} \mathrm{C}[6]$. & \\
\hline & & 1350 & & $\mathrm{La}_{2} \mathrm{O}_{3} \cdot \mathrm{Ga}_{2} \mathrm{O}_{3}+\mathrm{Ga}_{2} \mathrm{O}_{3}$ & Perovskite + beta gallia & $\begin{array}{l}\text { Orthorhombic+mono- } \\
\text { clinic. }\end{array}$ & & & & & & \\
\hline $\mathrm{Pr}_{2} \mathrm{O}_{3}-\mathrm{Ga}_{2} \mathrm{O}_{3}$ & $50: 50$ & & $\ldots$ & $\mathrm{Pr}_{2} \mathrm{O}_{3} \cdot \mathrm{Ga}_{2} \mathrm{O}_{3 \ldots-}$ & Perovskite. & Orthorhombic & 5. 465 & 5. 495 & 7.729 & & & Geller [6]. \\
\hline \multirow{3}{*}{$\mathrm{Nd}_{2} \mathrm{O}_{3}-\mathrm{Ga}_{2} \mathrm{O}_{3}$} & \multirow{3}{*}{$\begin{array}{c}75: 25 \\
66.7: 33.3\end{array}$} & 1350 & \multirow{3}{*}{$\begin{array}{l}6 \\
6 \\
6 \\
6\end{array}$} & & & & & & & & & \\
\hline & & $\begin{array}{l}1500 \\
1350\end{array}$ & & $\mathrm{Nd}_{2} \mathrm{O}_{3}+2 \mathrm{Nd}_{2} \mathrm{O}_{3} \cdot \mathrm{Ga}_{2} \mathrm{O}_{3}$ & A-type+unknown & Hexagonal+unknown & & & & & Specimen partially melted. & \\
\hline & & 1500 & & $\begin{array}{c}\mathrm{Nd}_{2} \mathrm{O}_{3}+2 \mathrm{Nd}_{2} \mathrm{O}_{3} \\
\mathrm{Ga}_{2} \mathrm{O}_{3}+\mathrm{Nd}_{2} \mathrm{O}_{3} . \\
\mathrm{Ga}_{2} \mathrm{O}_{3} .\end{array}$ & $\begin{array}{l}\text { A-Type-unknown } \\
\text { perovskite. }\end{array}$ & $\begin{array}{l}\text { Hexagonal+un- } \\
\text { known+orthorhom- } \\
\text { bic. }\end{array}$ & & & & & Nonequilibrium & \\
\hline
\end{tabular}




\begin{tabular}{|c|c|c|c|}
\hline & \multirow{2}{*}{$\begin{array}{l}50: 50 \\
40: 60\end{array}$} & & \\
\hline & & $\begin{array}{c}-1000 \\
1350\end{array}$ & $\begin{array}{c}6 \\
46 \\
46\end{array}$ \\
\hline & $37.5: 62.5$ & $\begin{array}{l}1000 \\
1350\end{array}$ & $\begin{array}{l}6 \\
6\end{array}$ \\
\hline \multirow[t]{5}{*}{$\mathrm{Sm}_{2} \mathrm{O}_{3}-\mathrm{Ga}_{2} \mathrm{O}_{3}$} & $75: 25$ & 1350 & 6 \\
\hline & $50: 50$ & $\begin{array}{l}1575 \\
1350\end{array}$ & 6 \\
\hline & $40 \cdot 60$ & 1000 & 20 \\
\hline & & $\begin{array}{l}1350 \\
1500\end{array}$ & $\begin{array}{r}6 \\
4 \\
4\end{array}$ \\
\hline & $37.5: 62.5$ & 1000 & 6 \\
\hline \multirow{5}{*}{$\mathrm{Eu}_{2} \mathrm{O}_{3}-\mathrm{Ga}_{2} \mathrm{O}_{3}$} & 75.05 & & \\
\hline & & & \\
\hline & $50: 50$ & $\begin{array}{l}15.50 \\
1350 \\
1500\end{array}$ & $\begin{array}{l}0 \\
6 \\
6\end{array}$ \\
\hline & $40: 60$ & $\begin{array}{l}1000 \\
1.50\end{array}$ & 6 \\
\hline & $37.5: 62.5$ & $\begin{array}{l}11500 \\
1000 \\
1350\end{array}$ & $\begin{array}{r}4^{4} 4 \\
6 \\
6\end{array}$ \\
\hline \multirow{5}{*}{$\mathrm{Gd}_{2} \mathrm{O}_{3}-\mathrm{Ga}_{2} \mathrm{O}_{3}$} & 75 & & \\
\hline & 50.50 & 1600 & 6 \\
\hline & & 1500 & \\
\hline & $40: 60$ & 1000 & 6 \\
\hline & $37.5: 62.5$ & $\begin{array}{l}15000 \\
1000 \\
1350\end{array}$ & $\begin{array}{r}44 \\
6 \\
6\end{array}$ \\
\hline \multirow[t]{7}{*}{$\mathrm{Dy}_{2} \mathrm{O}_{3}-\mathrm{Ga}_{2} \mathrm{O}_{3}$} & $75: 25$ & 1350 & 6 \\
\hline & & $\begin{array}{l}1600 \\
1600\end{array}$ & $\begin{array}{l}0 \\
6\end{array}$ \\
\hline & $66.7: 33.3$ & $\begin{array}{l}1650 \\
1350 \\
1500\end{array}$ & $\begin{array}{l}6 \\
6 \\
6\end{array}$ \\
\hline & $50: 50$ & $\begin{array}{l}1350 \\
1500\end{array}$ & $\begin{array}{l}6 \\
6\end{array}$ \\
\hline & $40: 60$ & 1000 & 6 \\
\hline & $37.5: 62.5$ & $\begin{array}{l}1500 \\
1000\end{array}$ & $\begin{array}{l}44 \\
6\end{array}$ \\
\hline & & $\begin{array}{l}1500 \\
1500\end{array}$ & $\begin{array}{l}40 \\
46\end{array}$ \\
\hline \multirow{5}{*}{$\mathrm{H}_{2} \mathrm{O}_{3}-\mathrm{Ga}_{2} \mathrm{O}_{3}$} & $75: 25$ & 1350 & 6 \\
\hline & & $\begin{array}{l}1600 \\
650\end{array}$ & 6 \\
\hline & $66.7: 33.3$ & $\begin{array}{l}1350 \\
1500\end{array}$ & ${ }_{6}^{6}$ \\
\hline & $50: 50$ & $\begin{array}{l}1350 \\
1500\end{array}$ & $\begin{array}{l}6 \\
6\end{array}$ \\
\hline & $40: 60$ & $\begin{array}{l}1000 \\
1350\end{array}$ & $\begin{array}{l}6 \\
6\end{array}$ \\
\hline
\end{tabular}

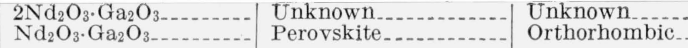

$|-5.426|-$

\begin{tabular}{|c|c|}
-5.502 & -7.706 \\
\hline
\end{tabular}

Geller [6].

$\mathrm{Nd}_{2} \mathrm{O}_{3} \mathrm{Ga}_{2} \mathrm{O}_{3}+$
$3 \mathrm{Nd}_{2} \mathrm{O}_{3} \cdot 5 \mathrm{Ga}_{2} \mathrm{O}_{3}$

Perovskitetgarnet

Orthorhombic+cubi

12. 505

$3 \mathrm{Nd}_{2} \mathrm{O}_{3} \cdot 5 \mathrm{Ga}_{2} \mathrm{O}_{3}$

Garnet.

Cubic-

12. 505

$3 \mathrm{Sm}_{2} \mathrm{O}_{3} \cdot \mathrm{Ga}_{2} \mathrm{O}_{3}+$

$\underset{3 \mathrm{Sm}_{2} \mathrm{O}_{3}}{2 \mathrm{Sm}_{2} \mathrm{GaO}_{3}} \cdot \mathrm{Ga}_{2}$

$2 \mathrm{Sm}_{2} \mathrm{O}_{3} \cdot \mathrm{Ga}_{2} \mathrm{O}_{3}+$

Unknown tunknow

Unknown+unknown

-

Ünknown+cubic..

$3 \mathrm{Sm}_{2} \mathrm{O}_{3} \cdot 5 \mathrm{Ga}_{2} \mathrm{O}_{3}$

${ }_{2}^{2} \mathrm{Sm}_{2} \mathrm{O}_{3} \cdot \mathrm{Ga}_{2} \mathrm{O}_{3}+$

Unknown

$3 \mathrm{Sm}_{2} \mathrm{O}_{3} \cdot 5 \mathrm{Ga}_{2} \mathrm{O}_{3}$

$3 \mathrm{Eu}_{2} \mathrm{O}_{3} \cdot \mathrm{Ga}_{2} \mathrm{O}_{3}+$
$2 \mathrm{Eu}_{2} \mathrm{O}_{3} \cdot \mathrm{Ga}_{2}$

$3 \mathrm{Eu}_{2} \mathrm{O}_{3} \cdot \mathrm{Ga}_{2} \mathrm{O}_{3}$

Unknown+garnet

12. 448

$2 \mathrm{Eu}_{2} \mathrm{O}_{3} \cdot \mathrm{Ga}_{2} \mathrm{O}_{3}+$

$3 \mathrm{Eu}_{2} \mathrm{O}_{3} \cdot 5 \mathrm{Ga}_{2} \mathrm{O}_{3}$ ss

$3 \mathrm{Eu}_{2} \mathrm{O}_{3} \cdot 5 \mathrm{Ga}_{2} \mathrm{O}_{3}$

Unknown+garnet

Unknown+eubic

12. 448

Garnet.

Cubic

$3 \mathrm{Eu}_{2} \mathrm{O}_{3} \cdot 5 \mathrm{Ga}_{2} \mathrm{O}_{3}$

$3 \mathrm{G}_{2} \mathrm{O}_{3} \cdot \mathrm{Ga}_{2} \mathrm{O}$

$3 \mathrm{Gd}_{2} \mathrm{O}_{3} \cdot \mathrm{Ga}_{2} \mathrm{O}$

$3 \mathrm{Gd}_{2} \mathrm{O}_{3} \cdot \mathrm{Ga}_{2} \mathrm{O}_{3}+$

Unknown+unknown

Unknown+unknown

12.434

Unknown

$3 \mathrm{Gd}_{2} \mathrm{O}_{3} \cdot 5 \mathrm{Ga}_{2} \mathrm{O}_{3} \mathrm{ss}$

$3 \mathrm{Gd}_{2} \mathrm{O}_{3} \cdot 5 \mathrm{Ga}_{2} \mathrm{O}_{3}$

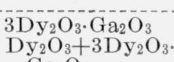

Unknown + garnet

Unknown+cubic

Garnet Cubic

12. 431

Cubic

12.422

$\mathrm{Ga}_{2} \mathrm{O}_{3}$

Garnet

wn

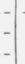

Unknown

$3 \mathrm{Dy}_{2} \mathrm{O}_{3} \cdot \mathrm{Ga}_{2} \mathrm{O}_{3}+$

$3 \mathrm{D}_{2} \mathrm{O}_{3} \cdot \mathrm{Ga}_{2} \mathrm{O}_{3}+$

$3 \mathrm{Dy}_{2} \mathrm{O}_{3} \cdot 5 \mathrm{Ga}_{2} \mathrm{O}_{3} 8$

$3 \mathrm{Dy}_{2} \mathrm{O}_{3} \cdot 5 \mathrm{Ga}_{2} \mathrm{O}_{3}$ ss

Unknowntgarnet

Unknown+eubic

Uarnet....

C-type+unknown

Cubic+unknown

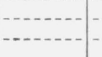

Unknown+cubic

$3 \mathrm{Dy}_{2} \mathrm{O}_{3} \cdot 5 \mathrm{Ga}_{2} \mathrm{O}_{3}$

$5 \mathrm{H}_{2} \mathrm{O}_{3}+3 \mathrm{H}_{2} \mathrm{O}_{3} \cdot \mathrm{Ga}_{2} \mathrm{O}_{3}$ -.-- do do.....-

$3 \mathrm{H}_{2} \mathrm{O}_{3} \cdot \mathrm{Ga}_{2} \mathrm{O}_{3}+$

$3 \mathrm{H}_{2} \mathrm{O}_{3} \cdot 5 \mathrm{Ga}_{2} \mathrm{O}_{3}$ ss

$3 \mathrm{H}_{2} \mathrm{O}_{3} \cdot \mathrm{Ga}_{2} \mathrm{O}_{3}+$ $3 \mathrm{HO}_{2} \mathrm{O}_{3} \cdot 5 \mathrm{Ga}_{2} \mathrm{O}_{3}$

$3 \mathrm{H}_{2} \mathrm{O}_{3} \cdot 5 \mathrm{Ga}_{2} \mathrm{O}_{3} 8 \mathrm{~s}$

See footnotes at end of table. 
TABLE 1.-Binary oxide mixtures of the trivalent cations-Continued

$\mathrm{Ga}^{+3}$ and larger cations-Continued

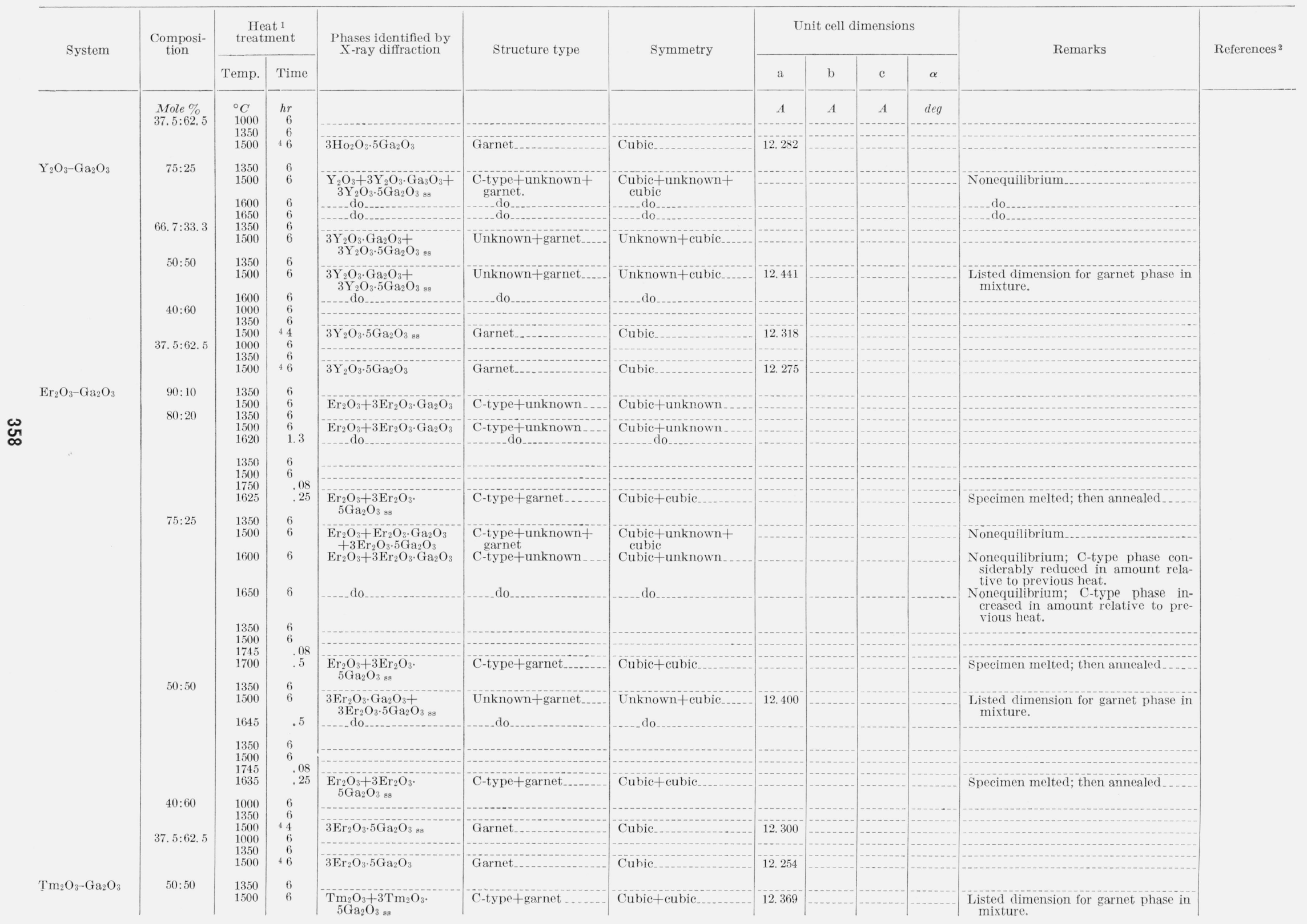


$\mathrm{Yb}_{2} \mathrm{O}_{3}-\mathrm{Ga}_{2} \mathrm{O}_{3}$

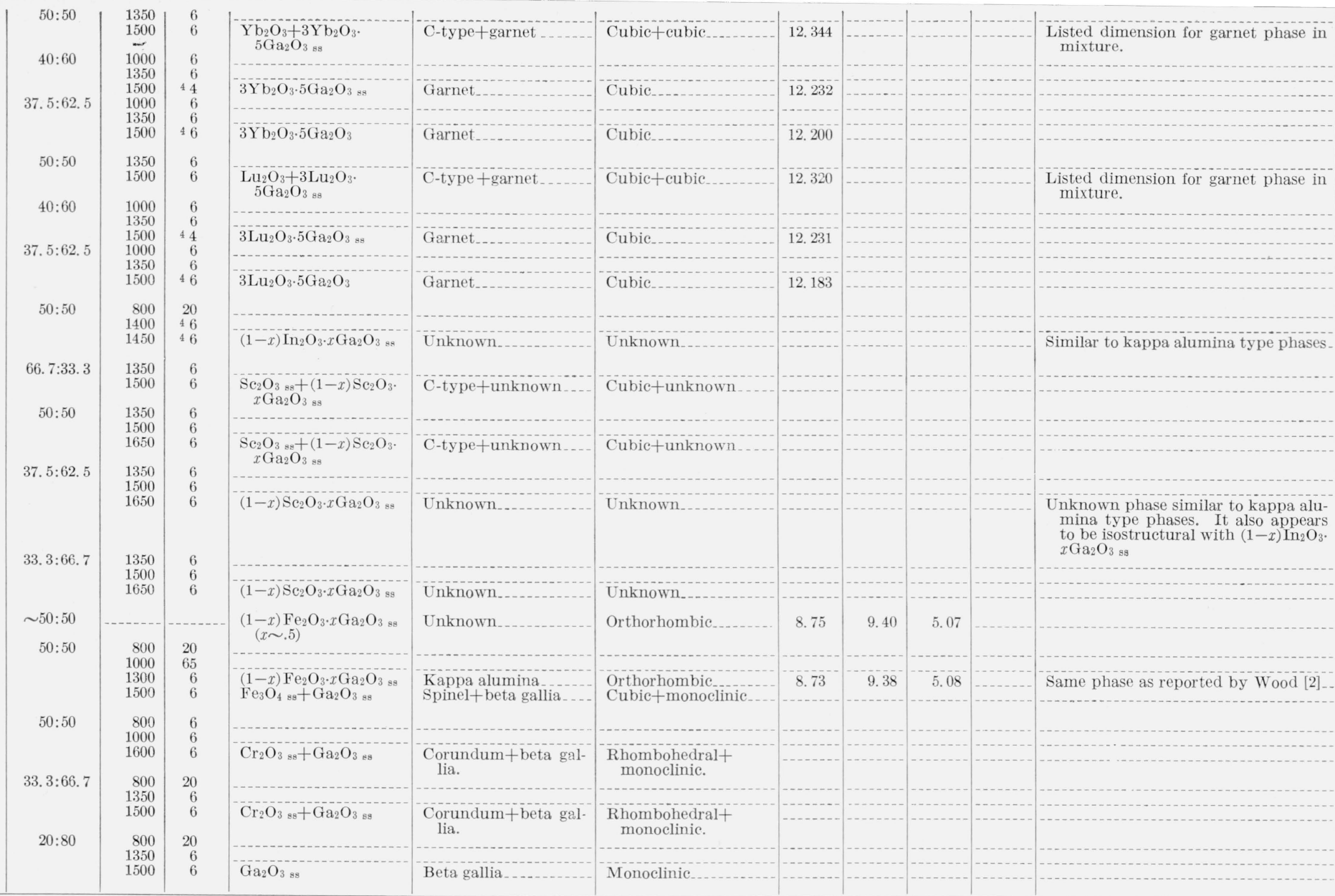

Wood [21]

$\mathrm{Cr}_{2} \mathrm{O}_{3}-\mathrm{Ga}_{2} \mathrm{O}_{3}$

\begin{tabular}{|c|c|c|c|c|c|c|}
\hline $\mathrm{La}_{2} \mathrm{O}_{3}-\mathrm{Cr}_{2} \mathrm{O}_{3}$ & $50: 50$ & & & $\mathrm{La}_{2} \mathrm{O}_{3} \cdot \mathrm{Cr}_{2} \mathrm{O}_{3}$ & Perovskite_.. & Orthorhombic \\
\hline $\mathrm{Pr}_{2} \mathrm{O}_{3}-\mathrm{Cr}_{2} \mathrm{O}_{3}$ & $50: 50$ & & & $\mathrm{Pr}_{2} \mathrm{O}_{3} \cdot \mathrm{Cr}_{2} \mathrm{O}_{3}$ & Perovskite_. & Orthorhombic... \\
\hline $\mathrm{Nd}_{2} \mathrm{O}_{3}-\mathrm{Cr}_{2} \mathrm{O}_{3}$ & $50: 50$ & & & $\mathrm{Nd}_{2} \mathrm{O}_{3} \cdot \mathrm{Cr}_{2} \mathrm{O}_{3}$ & Perovskite_ & Orthorhombic_.. \\
\hline \multirow[t]{5}{*}{$\mathrm{Sm}_{2} \mathrm{O}_{3}-\mathrm{Cr}_{2} \mathrm{O}_{3}$} & $66.7: 33.3$ & 800 & 20 & & & \\
\hline & & $\begin{array}{l}1350 \\
1500\end{array}$ & $\begin{array}{l}6 \\
6\end{array}$ & $\mathrm{Sm}_{2} \mathrm{O}_{3}+\mathrm{Sm}_{2} \mathrm{O}_{3} \cdot \mathrm{Cr}_{2} \mathrm{O}_{3}$ & B-type+perovskite & Monoclinic+ortho- \\
\hline & $50: 50$ & & & $\mathrm{Sm}_{2} \mathrm{O}_{3} \cdot \mathrm{Cr}_{2} \mathrm{O}_{3}$ & Perovskite_. & $\begin{array}{l}\text { rhombic. } \\
\text { Orthorhombic }\end{array}$ \\
\hline & $37.5: 62.5$ & 800 & 20 & & & \\
\hline & & $\begin{array}{l}1350 \\
1500\end{array}$ & $\begin{array}{l}6 \\
6\end{array}$ & $\mathrm{Sm}_{2} \mathrm{O}_{3} \cdot \mathrm{Cr}_{2} \mathrm{O}_{3}+\mathrm{Cr}_{2} \mathrm{O}_{3}$ & $\begin{array}{l}\text { Perovskite+corun- } \\
\text { dum }\end{array}$ & $\begin{array}{l}\text { Orthorhombic+rhom- } \\
\text { bohedral }\end{array}$ \\
\hline \multirow[t]{2}{*}{$\mathrm{Eu}_{2} \mathrm{O}_{3}-\mathrm{Cr}_{2} \mathrm{O}_{3}$} & $50: 50$ & 1000 & 6 & & & \\
\hline & & 1600 & 6 & $\mathrm{Eu}_{2} \mathrm{O}_{3} \cdot \mathrm{Cr}_{2} \mathrm{O}_{3}$ & Perovskite. & Orthorhombic_. \\
\hline
\end{tabular}

See footnotes at end of table. 
TABLE 1.-Binary oxide mixtures of the trivalent cations-Continued

$\mathrm{Cr}^{+3}$ and larger cations-Continued

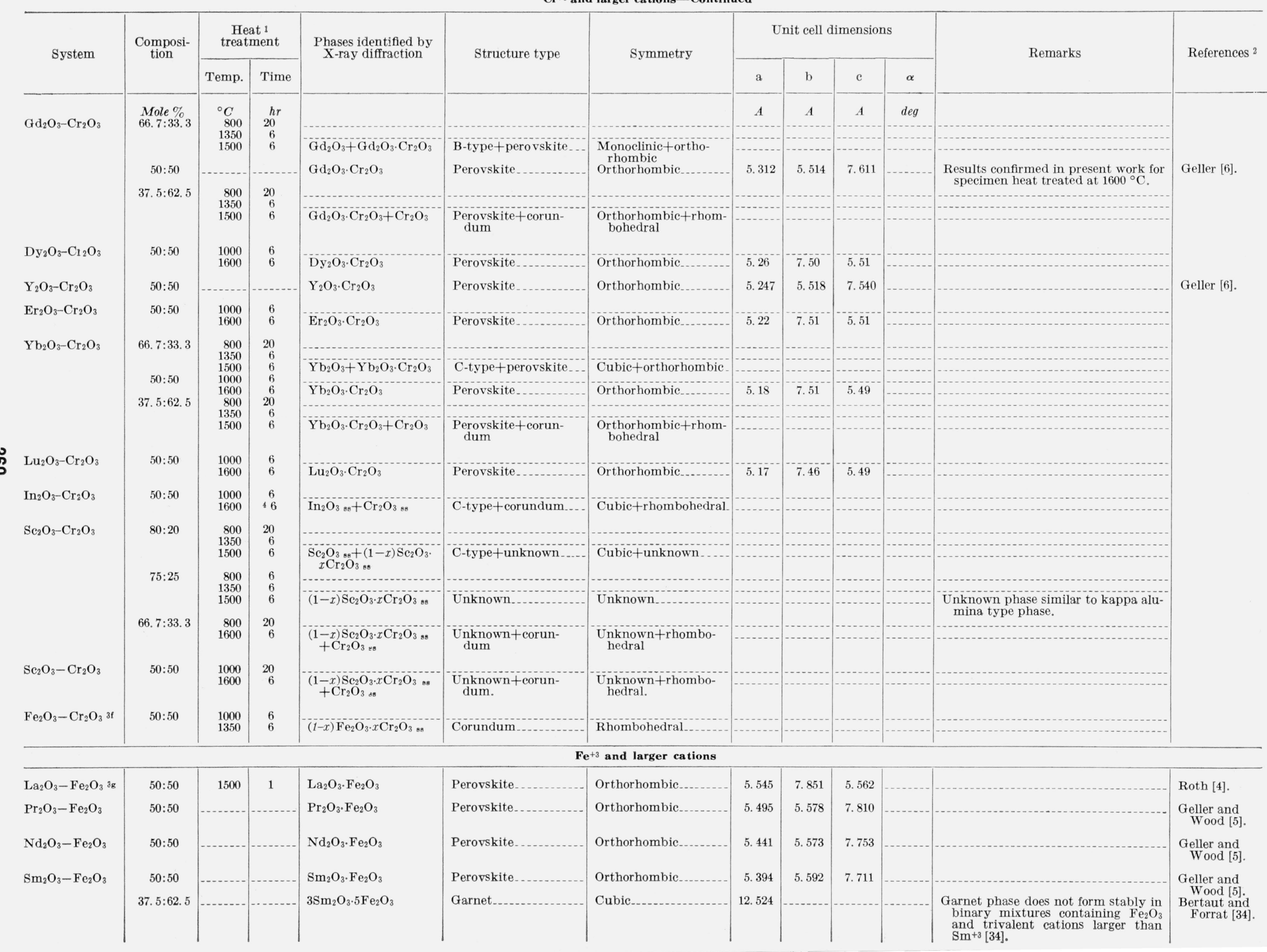




\begin{tabular}{|c|c|c|c|c|c|c|c|c|c|c|c|c|}
\hline \multirow[t]{2}{*}{${ }_{2} \mathrm{O}_{3}-\mathrm{Fe}_{2} \mathrm{O}_{3}$} & 50:50 & -..-- & ....... & $\mathrm{Eu}_{2} \mathrm{O}_{3} \cdot \mathrm{Fe}_{2} \mathrm{O}_{3}$ & Perovskite........... & Orthorhombic & 5. 371 & 5.611 & 7. 686 & & & Geller and \\
\hline & $37.5: 62.5$ & & & $3 \mathrm{Eu}_{2} \mathrm{O}_{3} \cdot 5 \mathrm{Fe}_{2} \mathrm{O}_{3}$ & Garnet_.....-.-. & Cubic_-_._._.-. & 12.518 & & & & & $\begin{array}{l}\text { Wood [5]. } \\
\text { Bertaut and }\end{array}$ \\
\hline \multirow[t]{2}{*}{$\mathrm{Gd}_{2} \mathrm{O}_{3}-\mathrm{Fe}_{2} \mathrm{O}_{3^{3 \mathrm{~h}}}$} & $50: 50$ & & & $\mathrm{Gd}_{2} \mathrm{O}_{3} \cdot \mathrm{Fe}_{2} \mathrm{O}_{3}$ & Perovskite - & Orthorhombic & 5. 346 & 5. 616 & 7.668 & & Results confirmed in present work for & Geller and \\
\hline & $37.5: 62.5$ & & & $3 \mathrm{Gd}_{2} \mathrm{O}_{3} \cdot 5 \mathrm{Fe}_{2} \mathrm{O}_{3}$ & Garnet_.. & Cubic_-. & 12. 479 & & & & & $\begin{array}{l}\text { Bertaut and } \\
\text { Forrat [34]. }\end{array}$ \\
\hline \multirow[t]{5}{*}{$\mathrm{Dy}_{2} \mathrm{O}_{3}-\mathrm{Fe}_{2} \mathrm{O}_{3}$} & 66. $7: 33.3$ & $\begin{array}{r}800 \\
1000\end{array}$ & $\begin{array}{l}20 \\
20\end{array}$ & & & & & & & & & \\
\hline & & $\begin{array}{l}1350 \\
800\end{array}$ & $\begin{array}{r}6 \\
6 \\
20\end{array}$ & $\mathrm{Dy}_{2} \mathrm{O}_{3}+\mathrm{Dy}_{2} \mathrm{O}_{3} \cdot \mathrm{Fe}_{2} \mathrm{O}_{3}$ & C-type+perovskite & Cubictorthorhombic- & $\cdots-\cdots$ & & & & & \\
\hline & $50: 50$ & 1000 & 65 & & & & & & & & & \\
\hline & & 1300 & 6 & $\mathrm{D}_{3} \mathrm{O}_{3} \cdot \mathrm{Fe}_{2} \mathrm{O}_{3}+$ & Perovskite+garnet.... & Orthorhombic+cubic & 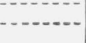 & -..... & ...... & & Nonequilibrium & \\
\hline & $37.5: 62.5$ & 1500 & 6 & $\begin{array}{l}\mathrm{Dy}_{2} \cdot \mathrm{Fe}_{2} \mathrm{~F}_{3} \\
3 \mathrm{D}_{2} \mathrm{O}_{3} \cdot 5 \mathrm{Fe}_{2} \mathrm{O}_{3}\end{array}$ & $\begin{array}{l}\text { Perovskite } \\
\text { Garnet }\end{array}$ & $\begin{array}{l}\text { Orthorhombic } \\
\text { Cubic }\end{array}$ & $\begin{array}{c}5.30 \\
12.414\end{array}$ & 7.62 & 5. 59 & & & Bertaut and \\
\hline \multirow[t]{3}{*}{$\mathrm{H}_{2} \mathrm{O}_{3}-\mathrm{Fe}_{2} \mathrm{O}_{3}$} & 50:50 & 800 & 20 & & & & & & & & & \\
\hline & & 1350 & $\begin{array}{r}65 \\
6\end{array}$ & $\mathrm{H}_{2} \mathrm{O}_{3} \cdot \mathrm{Fe}_{2} \mathrm{O}_{3}+$ & Perovskite+garnet...- & Orthorhombic+cubic & -...-- & -....-- & ....... & & Nonequilibrium.. & \\
\hline & $37.5: 62.5$ & 1500 & 6 & $\begin{array}{l}3 \mathrm{HO}_{2} \mathrm{O}_{3} \cdot 5 \mathrm{Fe}_{2} \mathrm{O}_{3} \\
\mathrm{HO}_{2} \mathrm{O}_{3} \cdot \mathrm{Fe}_{2} \mathrm{O}_{3} \\
3 \mathrm{HO}_{2} \mathrm{O}_{3} \cdot 5 \mathrm{Fe}_{2} \mathrm{O}_{3}\end{array}$ & $\begin{array}{l}\text { Perovskite } \\
\text { Garnet }\end{array}$ & $\begin{array}{l}\text { Orthorhombic } \\
\text { Cubic }\end{array}$ & $\begin{array}{c}5.30 \\
12.380\end{array}$ & 7. 58 & 5.59 & & & Bertaut and \\
\hline $\mathrm{Y}_{2} \mathrm{O}_{3}-\mathrm{Fe}_{2} \mathrm{O}_{3}{ }_{3 \mathrm{i}}$ & & 1500 & 1 & & Perovskite_... & & 5. 279 & 7. 609 & 5.590 & & & $\begin{array}{l}\text { Forrat [34]. } \\
\text { Roth [4]. }\end{array}$ \\
\hline & $37.5: 62.5$ & & $\ldots$ & $3 \mathrm{Y}_{2} \mathrm{O}_{3} \cdot 5 \mathrm{Fe}_{2} \mathrm{O}_{3}$ & Garnet......- & Cubic & 12.376 & & & & & $\begin{array}{l}\text { Bertaut and } \\
\text { Forrat [34]. }\end{array}$ \\
\hline \multirow[t]{3}{*}{$\mathrm{Er}_{2} \mathrm{O}_{3}-\mathrm{Fe}_{2} \mathrm{O}_{3}$} & $50: 50$ & $\begin{array}{r}800 \\
1000\end{array}$ & $\begin{array}{l}20 \\
65\end{array}$ & & & & & & & & & \\
\hline & & $\begin{array}{l}1300 \\
1500\end{array}$ & $\begin{array}{r}5 \\
6 \\
6\end{array}$ & $\mathrm{Er}_{2} \mathrm{O}_{3} \cdot \mathrm{Fe}_{2} \mathrm{O}_{3}$ & Peroyskite & Orthorhombic & & & $=0$ & & & \\
\hline & $37.5: 62.5$ & & & $\begin{array}{l}\mathrm{Er}_{2} \mathrm{O}_{3} \mathrm{O}_{2} \cdot \mathrm{E}_{2} \mathrm{O}_{3} \\
3 \mathrm{Er}_{2} \mathrm{O}_{3} \cdot 5 \mathrm{Fe}_{2} \mathrm{O}_{3}\end{array}$ & Garnet_.................... & Cubic_._. & $\begin{aligned} \text { 5. } 26 \\
12.349\end{aligned}$ & 7.58 & 5.58 & & & Bertaut and \\
\hline $\mathrm{Tm}_{2} \mathrm{O}_{3}-\mathrm{Fe}_{2} \mathrm{O}_{3}$ & $37.5: 62.5$ & & & $3 \mathrm{Tm}_{2} \mathrm{O}_{3} \cdot 5 \mathrm{Fe}_{2} \mathrm{O}_{3}$ & Garnet.... & Cubic & 12. 325 & & & & & $\begin{array}{l}\text { Bertaut and } \\
\text { Forrat [34]. }\end{array}$ \\
\hline \multirow[t]{5}{*}{$\mathrm{Yb}_{2} \mathrm{O}_{3}-\mathrm{Fe}_{2} \mathrm{O}_{3}$} & 66. $7: 33.3$ & 800 & 20 & ...... & & & & & & & & \\
\hline & & $\begin{array}{l}1000 \\
1350\end{array}$ & $\begin{array}{r}20 \\
6\end{array}$ & $\mathrm{Y} \mathrm{b}_{2} \mathrm{O}_{3}+\mathrm{Yb}_{2} \mathrm{O}_{3} \cdot \mathrm{Fe}_{2} \mathrm{O}_{3}$ & C-type+perovskite-. & Cubic+orthorhombic & & & & & & \\
\hline & $50: 50$ & $\begin{array}{r}800 \\
1000\end{array}$ & $\begin{array}{l}20 \\
65\end{array}$ & & & & & & & & & \\
\hline & & 1300 & $\begin{array}{r}63 \\
6\end{array}$ & - & & & & & & & & \\
\hline & $37.5: 62.5$ & 1500 & 6 & $\begin{array}{l}\mathrm{Yb}_{2} \mathrm{O}_{3} \cdot \mathrm{Fe}_{2} \mathrm{O}_{3} \\
3 \mathrm{Yb}_{2} \mathrm{O}_{3} \cdot 5 \mathrm{Fe}_{2} \mathrm{O}_{3}\end{array}$ & $\begin{array}{l}\text { Perovskite } \\
\text { Garnet }\end{array}$ & $\begin{array}{l}\text { Orthorhombic } \\
\text { Cubic }\end{array}$ & $\begin{array}{r}5.22 \\
12.291\end{array}$ & 7.56 & 5.58 & & & Bertaut and \\
\hline \multirow[t]{4}{*}{$\mathrm{Lu}_{2} \mathrm{O}_{3}-\mathrm{Fe}_{2} \mathrm{O}_{3}$} & $50: 50$ & 800 & 20 & & & & & & & & , & \\
\hline & & $\begin{array}{l}1000 \\
1300\end{array}$ & $\begin{array}{r}65 \\
6\end{array}$ & $\mathrm{Lu}_{2} \mathrm{O}_{3} \cdot \mathrm{Fe}_{2} \mathrm{O}_{3}$ & Perovskite & Orthorhombic & 5.21 & 7.55 & 5,55 & & & \\
\hline & $37.5 \cdot 62.5$ & 1500 & 6 & $3 \mathrm{Lu}_{2} \mathrm{O}_{2} .5 \mathrm{FeO}_{3}$ & Garnet. & do do....... & $\begin{array}{c}0.21 \\
-10.07\end{array}$ & & & & & \\
\hline & 51.0 .02 .0 & & & $3 \mathrm{Lu}_{2} \mathrm{O}_{3} \cdot 5 \mathrm{Fe}_{2} \mathrm{O}_{3}$ & Garnet... & Cubic_- & 12. 277 & & & & & $\begin{array}{l}\text { Bertaut and } \\
\text { Forrat [34]. }\end{array}$ \\
\hline \multirow[t]{2}{*}{$\mathrm{In}_{2} \mathrm{O}_{3}-\mathrm{Fe}_{2} \mathrm{O}_{3}$} & $50: 50$ & $\begin{array}{r}800 \\
1000\end{array}$ & 20 & & & & & & & & & \\
\hline & & $\begin{array}{l}1000 \\
1350 \\
1500\end{array}$ & $\begin{array}{r}60 \\
6 \\
46\end{array}$ & $\mathrm{In}_{2} \mathrm{O}_{3 \mathrm{~s}}+\mathrm{Fe}_{2} \mathrm{O}_{3} \mathrm{ss}$ & C-type + corundum & Cubic+rhombohedral & & & & & & \\
\hline \multirow{5}{*}{$\mathrm{Sc}_{2} \mathrm{O}_{3}-\mathrm{Fe}_{2} \mathrm{O}_{3}{ }^{3 \mathrm{I}}$} & $50: 50$ & & 20 & - . _ do & -.... do & $-\ldots . d$ & & & & & & \\
\hline & $00: 00$ & $\begin{array}{l}800 \\
1000\end{array}$ & 65 & & & & & & & & & \\
\hline & & $\begin{array}{l}1350 \\
1500\end{array}$ & $\begin{array}{l}6 \\
6\end{array}$ & $\begin{array}{l}\mathrm{Sc}_{2} \mathrm{O}_{38}+\mathrm{Fe}_{2} \mathrm{O}_{3} 88 \\
\mathrm{Sc}_{2} \mathrm{O}_{3}\end{array}$ & C-type+corundum & Cubic+rhombohedral & $\ldots$ & & & & Nonequilibrium & \\
\hline & $37.5: 62.5$ & 800 & 20 & $\mathrm{Sc}_{2} \mathrm{O}_{3} \mathrm{ss}$ & C-type & 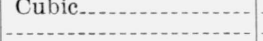 & & & & & & \\
\hline & & $\begin{array}{l}1000 \\
1350\end{array}$ & $\begin{array}{r}20 \\
6\end{array}$ & $\mathrm{Se}_{2} \mathrm{O}_{3} \mathrm{so}+\mathrm{Fe}_{2} \mathrm{O}_{3} \mathrm{se}$ & C-type+corundum & Cubic+rhombohedral & & & & & & \\
\hline & & & & & & & & & & & & \\
\hline
\end{tabular}

$\mathrm{Sc}^{+3}$ and larger cations

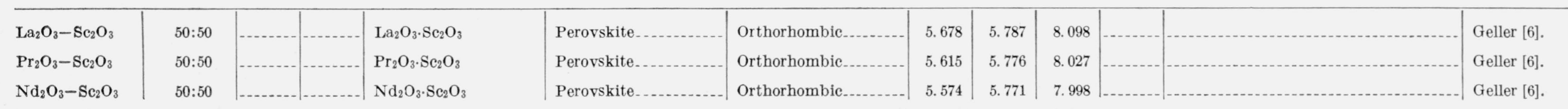

See footnotes at end of table. 
TABLE 1.-Binary oxide mixtures of the trivalent cations - Continued

$\mathrm{Sc}^{+3}$ and larger cations-Continued

\begin{tabular}{|c|c|c|c|c|c|c|c|c|c|c|c|c|}
\hline \multirow{2}{*}{ System } & \multirow{2}{*}{$\begin{array}{l}\text { Composi- } \\
\text { tion }\end{array}$} & \multicolumn{2}{|c|}{$\begin{array}{l}\text { Heat } 1 \\
\text { treatment }\end{array}$} & \multirow{2}{*}{$\begin{array}{l}\text { Phases identified by } \\
\text { X-ray diffraction }\end{array}$} & \multirow{2}{*}{ Structure type } & \multirow{2}{*}{ Symmetry } & \multicolumn{4}{|c|}{ Unit cell dimensions } & \multirow{2}{*}{ Remarks } & \multirow{2}{*}{ References $^{2}$} \\
\hline & & Temp. & Time & & & & a & b & $\mathrm{c}$ & $\alpha$ & & \\
\hline \multirow{2}{*}{$\mathrm{Sm}_{2} \mathrm{O}_{3}-\mathrm{Sc}_{2} \mathrm{O}_{3}$} & \multirow{2}{*}{$\begin{array}{c}\text { Mole } \% \\
50: 50\end{array}$} & \multirow{2}{*}{$\begin{array}{l}{ }^{\circ} C \\
1350 \\
1650\end{array}$} & \multirow{2}{*}{$\begin{array}{l}h r \\
6 \\
9.5\end{array}$} & & & & $A$ & $A$ & $A$ & deg & & \multirow{25}{*}{ Geller [6]. } \\
\hline & & & & $\mathrm{Sm}_{2} \mathrm{O}_{3} \cdot \mathrm{Sc}_{2} \mathrm{O}_{3}$ & Perovskite & Orthorhombic & 5.53 & 7.95 & 5. 76 & & & \\
\hline $\mathrm{Eu}_{2} \mathrm{O}_{3}-\mathrm{Se}_{2} \mathrm{O}_{3}$ & \multirow[t]{2}{*}{$50: 50$} & $\begin{array}{l}1350 \\
1650\end{array}$ & $\begin{array}{l}6 \\
9.5\end{array}$ & & & & & & & & & \\
\hline \multirow{6}{*}{$\mathrm{Gd}_{2} \mathrm{O}_{3}-\mathrm{Sc}_{2} \mathrm{O}_{3}$} & & & & & Ferovskile & Orthornombic & 5.51 & 7. 94 & 5.76 & & & \\
\hline & \multirow{2}{*}{ 66. $7: 33.3$} & 1500 & 6 & \multirow{3}{*}{$\begin{array}{l}\mathrm{Gd}_{2} \mathrm{O}_{3} \mathrm{ss}+\mathrm{Gd}_{2} \mathrm{O}_{3} \cdot \\
\mathrm{Se}_{2} \mathrm{O}_{3} \\
\mathrm{Gd}_{2} \mathrm{O}_{3} \cdot \mathrm{Sc}_{2} \mathrm{O}_{3}\end{array}$} & & & & & & & & \\
\hline & & 1650 & 6 & & B-type+perovskite & $\begin{array}{l}\text { Monoclinic +ortho- } \\
\text { rhombic }\end{array}$ & & & & & & \\
\hline & $50: 50$ & & $\cdots$ & & Perovskite ... & Orthorhombic & 5. 487 & 5. 756 & 7.925 & & Results confirmed in present work for & \\
\hline & $37.5: 62.5$ & $\begin{array}{l}1350 \\
1500\end{array}$ & $\begin{array}{l}6 \\
6\end{array}$ & $\mathrm{Gd}_{2} \mathrm{O}_{3} \cdot \mathrm{Sc}_{2} \mathrm{O}_{3}+\mathrm{Sc}_{2} \mathrm{O}_{3 s s}$ & Perovskite+ C-type & Orthorhombic + cubic & & & & & & \\
\hline & & 1650 & 6 & _.._do & _.... do & 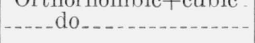 & & & & & & \\
\hline \multirow[t]{3}{*}{$\mathrm{Dy}_{2} \mathrm{O}_{3}-\mathrm{Sc}_{2} \mathrm{O}_{3}$} & \multirow{3}{*}{$\begin{array}{c}66.7: 33.3 \\
50: 50\end{array}$} & 1350 & 6 & & & & & & & & & \\
\hline & & $\begin{array}{l}1500 \\
1350\end{array}$ & $\begin{array}{l}6 \\
6 \\
6\end{array}$ & $\mathrm{Dy}_{2} \mathrm{O}_{3} \mathrm{~s}+\mathrm{Dy}_{2} \mathrm{O}_{3} \cdot \mathrm{Sc}_{2} \mathrm{O}_{3}$ & C-type+perovskite -.. & Cubic-orthorhombic_- & & & & & & \\
\hline & & 1650 & 9.5 & $\mathrm{Dy}_{2} \mathrm{O}_{3} \cdot \mathrm{Sc}_{2} \mathrm{O}_{3}$ & Perovskite & Orthorhombic_-.--..--- & 5.43 & 7.89 & 5. 71 & & & \\
\hline \multirow[t]{4}{*}{$\mathrm{Ho}_{2} \mathrm{O}_{3}-\mathrm{Sc}_{2} \mathrm{O}_{3}$} & \multirow[t]{4}{*}{$50: 50$} & $\begin{array}{l}1350 \\
1650\end{array}$ & $\begin{array}{l}6 \\
9,5\end{array}$ & & & & & & & & & \\
\hline & & $\begin{array}{l}1875 \\
1900\end{array}$ & 0.3 & $\begin{array}{r}\mathrm{HO}_{2} \mathrm{O}_{3}+\mathrm{Ho}_{2}+\mathrm{Ho}_{2} \\
\mathrm{Sc}_{2} \mathrm{O}_{3}+\mathrm{Sc}_{2} \mathrm{O}_{3} \\
\mathrm{dO}_{3}\end{array}$ & $\begin{array}{l}\text { C-type+perovskite }+ \\
\text { C-type }\end{array}$ & $\begin{array}{l}\text { Cubic+orthorhombic } \\
\text { +cubic }\end{array}$ & 5.42 & 7.87 & 5.71 & & $\begin{array}{l}\text { Nonequilibrium listed dimensions for } \\
\text { perovskite phase in mixture. }\end{array}$ & \\
\hline & & $\begin{array}{l}1900 \\
1950\end{array}$ & $\begin{array}{l}1 \\
1\end{array}$ & 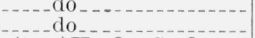 & - do do & 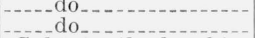 & & & & & $\begin{array}{l}\text { Nonequilibrium } \\
\text { do }\end{array}$ & \\
\hline & & 2000 & 0.3 & $\begin{array}{c}(1-x) \mathrm{Ho}_{2} \mathrm{O}_{3} \cdot x \mathrm{Sc}_{2} \mathrm{O}_{3} \\
+\mathrm{Ho}_{2} \mathrm{O}_{3} \cdot \mathrm{Se}_{2} \mathrm{O}_{3}\end{array}$ & C-type+perovskite & Cubic+orthorhombic & & & & & $\begin{array}{l}\text { Nonequilibrium; amount of perov- } \\
\text { skite phase small. Equilibrium } \\
\text { probably single phase C-type solid } \\
\text { solution. }\end{array}$ & \\
\hline \multirow[t]{2}{*}{$\mathrm{Y}_{2} \mathrm{O}_{3}-\mathrm{Sc}_{2} \mathrm{O}_{3}$} & \multirow[t]{2}{*}{$50: 50$} & $\begin{array}{l}1350 \\
1650\end{array}$ & $\begin{array}{l}6 \\
9.5\end{array}$ & $\mathrm{Y}_{2} \mathrm{O}_{3} \mathrm{ss}+\mathrm{Y}_{2} \mathrm{O}_{3} \cdot \mathrm{Se}_{2} \mathrm{O}_{3}+$ & C-type+perovskite & Cubic +orthorhombic & & & & & Nonequilibrium & \\
\hline & & 1890 & 0.3 & $(1-x) \mathrm{Y}_{2} \mathrm{O}_{3} \cdot x \mathrm{Se}_{2} \mathrm{O}_{3} \mathrm{ss}$ & $\begin{array}{l}\text { +C-type } \\
\text { C-type-- }\end{array}$ & $\begin{array}{l}\quad+\text { cubic } \\
\text { Cubic }\end{array}$ & & & & & & \\
\hline \multirow[t]{2}{*}{$\mathrm{Er}_{2} \mathrm{O}_{3}-\mathrm{Se}_{2} \mathrm{O}_{3}$} & \multirow[t]{2}{*}{$50: 50$} & 1350 & 6 & & & & & & & & & \\
\hline & & $\begin{array}{l}1650 \\
1850\end{array}$ & $\begin{array}{l}9.5 \\
0.7\end{array}$ & $\begin{array}{l}\mathrm{Er}_{2} \mathrm{O}_{3} \mathrm{ss}_{2}+\mathrm{Sc}_{2} \mathrm{O}_{3} \mathrm{ss} \\
(1-x) \mathrm{Er}_{2} \mathrm{O}_{3} \cdot x \mathrm{Sc}_{2} \mathrm{O}_{3}\end{array}$ & $\begin{array}{l}\text { C-type+C-type- } \\
\text { C-type- }\end{array}$ & $\begin{array}{l}\text { Cubic+cubic - } \\
\text { Cubic. }\end{array}$ & & & & & Nonequilibrium & \\
\hline \multirow[t]{2}{*}{$\mathrm{Yb}_{2} \mathrm{O}_{3}-\mathrm{Sc}_{2} \mathrm{O}_{3}$} & \multirow[t]{2}{*}{$50: 50$} & 1350 & 6 & & & & & & & & & \\
\hline & & $\begin{array}{l}1650 \\
1850\end{array}$ & $\begin{array}{l}9.5 \\
0.3\end{array}$ & $\begin{array}{l}\mathrm{Yb}_{2} \mathrm{O}_{3} \mathrm{ss}_{2}+\mathrm{Sc}_{2} \mathrm{O}_{3} \mathrm{ss} \\
(1-x) \mathrm{Yb}_{2} \mathrm{O}_{3} \cdot x \mathrm{Sc}_{2} \mathrm{O}_{3} \mathrm{ss}\end{array}$ & $\begin{array}{l}\text { C-type+C-type } \\
\text { C-type }\end{array}$ & $\begin{array}{l}\text { Cubic+cubic_- } \\
\text { Cubic }\end{array}$ & & & & & Nonequilibrium & \\
\hline $\mathrm{Lu}_{2} \mathrm{O}_{3}-\mathrm{Se}_{2} \mathrm{O}_{3}$ & $50: 50$ & 1350 & 6 & & & & & & & & & \\
\hline $\mathrm{In}_{2} \mathrm{O}_{3}-\mathrm{Sc}_{2} \mathrm{O}_{3}$ & & 1650 & 9.5 & $(1-x) \mathrm{Lu}_{2} \mathrm{O}_{3} \cdot x \mathrm{Se}_{2} \mathrm{O}_{3} \mathrm{~s}$ & C-type_-- & Cubic & & & & & & \\
\hline $\mathrm{MT}_{2} \mathrm{O}_{3}-\mathrm{NC}_{2} \mathrm{O}_{3}$ & 50:50 & $\begin{array}{r}800 \\
1350\end{array}$ & $\begin{array}{l}20 \\
46\end{array}$ & $(1-x) \mathrm{In}_{2} \mathrm{O}_{3} \cdot x \mathrm{Sec}_{2} \mathrm{O}_{3} \mathrm{ss}$ & C-type- & Cubic- & & & & & & \\
\hline
\end{tabular}

\section{In ${ }^{+3}$ and larger cations}

\begin{tabular}{|c|c|c|c|c|c|c|c|c|c|c|}
\hline $\mathrm{La}_{2} \mathrm{O}_{3}-\mathrm{In}_{2} \mathrm{O}_{3}$ & $50: 50$ & 1350 & 0.5 & $\mathrm{La}_{2} \mathrm{O}_{3} \cdot \mathrm{In}_{2} \mathrm{O}_{3}$ & Perovskite & Orthorhombic & 5. 723 & 8. 207 & 5.914 & Roth [4]. \\
\hline \multirow[t]{6}{*}{$\mathrm{Nd}_{2} \mathrm{O}_{3}-\mathrm{In}_{2} \mathrm{O}_{3}$} & $95: 5$ & 800 & 20 & & & & & & & \\
\hline & & $\begin{array}{l}1350 \\
1500\end{array}$ & $\begin{array}{r}6 \\
42 \\
4\end{array}$ & $(1-x) \mathrm{Nd}_{2} \mathrm{O}_{3} \cdot x \mathrm{In}_{2} \mathrm{O}_{3} \mathrm{ss}$ & B-type & Monoclinic & & & & \\
\hline & $85: 15$ & 800 & 20 & & & & & & & \\
\hline & & 1500 & 42 & $(1-x) \mathrm{Nd}_{2} \mathrm{O}_{3} \cdot x \mathrm{In}_{2} \mathrm{O}_{3}$ & B-type + perovskite & Monoclinic + ortho- & & & & \\
\hline & $75: 25$ & 800 & 20 & & & & & & & \\
\hline & $66.7: 33.3$ & $\begin{array}{r}1500 \\
800\end{array}$ & $\begin{array}{l}42 \\
20\end{array}$ & $\begin{array}{l}(1-x) \mathrm{Nd}_{2} \mathrm{O}_{3} \cdot x \mathrm{In}_{2} \mathrm{O}_{3} \mathrm{ss} \\
+\mathrm{Nd}_{2} \mathrm{O}_{3} \cdot \mathrm{In}_{2} \mathrm{O}_{3}\end{array}$ & B-type+perovskite & $\begin{array}{l}\text { Monoclinic +ortho- } \\
\text { rhombic. }\end{array}$ & & & & \\
\hline
\end{tabular}




\begin{tabular}{|c|c|c|c|c|c|c|}
\hline \multirow[t]{4}{*}{$\mathrm{Sm}_{2} \mathrm{O}_{3}-\mathrm{In}_{2} \mathrm{O}_{3}$} & \multirow{4}{*}{$\begin{array}{c}66.7: 33.3 \\
\\
50: 50 \\
33.3: 66.7\end{array}$} & \multirow{4}{*}{$\begin{array}{r}800 \\
1350 \\
1500 \\
1350 \\
800 \\
1350 \\
1500\end{array}$} & \multirow{2}{*}{$\begin{array}{r}20 \\
6 \\
42\end{array}$} & - & & \\
\hline & & & & $\mathrm{Sm}_{2} \mathrm{O}_{3} \mathrm{ss}+\mathrm{Sm}_{2} \mathrm{O}_{3}$. & B-type+perovskite & Monoclinic+ortho- \\
\hline & & & ${ }_{20}^{0.5}$ & $\mathrm{Sm}_{2} \mathrm{O}_{3} \cdot \mathrm{In}_{2} \mathrm{O}_{3}$ & Perovskite ... & $\begin{array}{l}\text { rhombic. } \\
\text { Orthorhombic }\end{array}$ \\
\hline & & & $\begin{array}{r}6 \\
42\end{array}$ & $\mathrm{Sm}_{2} \mathrm{O}_{3} \cdot \mathrm{In}_{2} \mathrm{O}_{3}+\mathrm{In}_{2} \mathrm{O}_{3} \mathrm{ss}$ & Perovskite + -type & Orthorhombic + cub \\
\hline \multirow[t]{2}{*}{$\mathrm{Eu}_{2} \mathrm{O}_{3}-\mathrm{In}_{2} \mathrm{O}_{3}{ }^{3 \mathrm{k}}$} & \multirow[t]{2}{*}{$50: 50$} & 800 & 20 & & & \\
\hline & & $\begin{array}{l}1350 \\
1650\end{array}$ & $\begin{array}{r}6 \\
42 \\
4\end{array}$ & $\mathrm{Eu}_{2} \mathrm{O}_{3} \cdot \mathrm{In}_{2} \mathrm{O}_{3}$ & Unknown & Unknown \\
\hline \multirow[t]{7}{*}{$\mathrm{Gd}_{2} \mathrm{O}_{3}-\mathrm{In}_{2} \mathrm{O}_{3}$} & \multirow[t]{2}{*}{$66.7: 33.3$} & 800 & 20 & & & \\
\hline & & $\begin{array}{l}1350 \\
1600\end{array}$ & $\begin{array}{r}6 \\
4 \\
2\end{array}$ & $\mathrm{Gd}_{2} \mathrm{O}_{3 s s}+\mathrm{Gd}_{2} \mathrm{O}_{3}$. & B-type+unknown & Monoclinic+un- \\
\hline & \multirow[t]{3}{*}{$50: 50$} & 800 & 20 & $\mathrm{In}_{2} \mathrm{O}_{3}$ & & known. \\
\hline & & $\begin{array}{l}1350 \\
1600\end{array}$ & $\begin{array}{r}6 \\
41\end{array}$ & $\mathrm{Gd}_{2} \mathrm{O}_{3} \cdot \mathrm{In}_{2} \mathrm{O}_{3}$ & Unknown & Unknown \\
\hline & & 1650 & ${ }^{4} 2$ & .... do do & do & Udown \\
\hline & \multirow{2}{*}{$33.3: 66.7$} & $\begin{array}{r}800 \\
1350\end{array}$ & $\begin{array}{r}20 \\
6\end{array}$ & & & \\
\hline & & 1600 & ${ }^{4} 2$ & $\begin{array}{c}\mathrm{G} \mathrm{d}_{2} \mathrm{O}_{3} \cdot \mathrm{In}_{2} \mathrm{O}_{3} \mathrm{ss} \\
\quad+\mathrm{In}_{2} \mathrm{O}_{2} \mathrm{ss}\end{array}$ & Unknown+C-type & Unknown+cubic \\
\hline \multirow[t]{12}{*}{$\mathrm{Dy}_{2} \mathrm{O}_{3}-\mathrm{In}_{2} \mathrm{O}_{3}$} & \multirow[t]{2}{*}{$95: 5$} & 800 & 20 & & & \\
\hline & & 1600 & $\begin{array}{l}0 \\
42\end{array}$ & $\begin{array}{c}\mathrm{Dy}_{2} \mathrm{O}_{3} s \mathrm{~s}+(1-x) \\
\mathrm{Dy}_{2} \mathrm{O}_{3} \cdot x \mathrm{In}_{2} \mathrm{O}_{3}\end{array}$ & C-type+B-type & Cubic+monoclini \\
\hline & \multirow[t]{2}{*}{$85: 5$} & $\begin{array}{r}800 \\
1350\end{array}$ & $\begin{array}{r}20 \\
6\end{array}$ & & & \\
\hline & & 1600 & ${ }^{4} 2$ & $\begin{array}{c}\mathrm{DV}_{2} \mathrm{O}_{38}+(1-x) \\
\mathrm{Dy}_{2} \mathrm{O}_{3} \cdot x \mathrm{In}_{2} \mathrm{O}_{3}\end{array}$ & C-type+B-type & Cubic + monoclinic \\
\hline & $75: 25$ & $\begin{array}{r}800 \\
1350\end{array}$ & $\begin{array}{r}20 \\
6\end{array}$ & & & \\
\hline & \multirow[t]{2}{*}{$66.7: 33.3$} & $\begin{array}{r}1600 \\
800\end{array}$ & $\begin{array}{l}42 \\
20\end{array}$ & $(1-x) \mathrm{Dy}_{2} \mathrm{O}_{3} \cdot x \mathrm{In}_{2} \mathrm{O}_{3} \mathrm{ss}$ & B-type & Monoclinic \\
\hline & & 1350 & 6 & & & \\
\hline & \multirow[t]{3}{*}{$50: 50$} & & $\begin{array}{l}42 \\
20\end{array}$ & $\begin{array}{l}(1-x) \mathrm{Dy}_{2} \mathrm{O}_{3} \cdot x \mathrm{In}_{2} \mathrm{O}_{3 s} \\
\quad+\mathrm{Dy}_{2} \mathrm{O}_{3} \cdot \mathrm{In}_{2} \mathrm{O}_{3 s}\end{array}$ & B-type+unknown & $\begin{array}{l}\text { Monoclinic+un- } \\
\text { known. }\end{array}$ \\
\hline & & $\begin{array}{l}1350 \\
1600\end{array}$ & $\begin{array}{r}6 \\
41\end{array}$ & $\mathrm{Dy}_{2} \mathrm{O}_{3} \cdot \mathrm{In}_{2} \mathrm{O}_{3}$ & Unknow & Unknown \\
\hline & & 1650 & ${ }^{4} 3$ & $(1-x) \mathrm{Dy}_{2} \mathrm{O}_{3} \cdot x \mathrm{In}_{2} \mathrm{O}_{3} \mathrm{ss}$ & B-type +C-type & Monoclinic +cubic \\
\hline & \multirow[t]{2}{*}{$33.3: 66.7$} & 800 & 20 & +11 & & \\
\hline & & $\begin{array}{l}1350 \\
1600\end{array}$ & $\begin{array}{r}6 \\
42\end{array}$ & $\begin{array}{l}\mathrm{D}_{2} \mathrm{O}_{3} \cdot \mathrm{In}_{2} \mathrm{O}_{3 s s}+ \\
\mathrm{In}_{2} \mathrm{O}_{3} \mathrm{ss}\end{array}$ & Unknown+C-type & Unknown+cubic \\
\hline \multirow[t]{2}{*}{$\mathrm{Ho}_{2} \mathrm{O}_{3}-\mathrm{In}_{2} \mathrm{O}_{3}$} & \multirow[t]{2}{*}{$50: 50$} & $\begin{array}{r}800 \\
1350\end{array}$ & $\begin{array}{r}20 \\
6\end{array}$ & & & \\
\hline & & 1600 & ${ }^{4} 1$ & $(1-x) \mathrm{HO}_{2} \mathrm{O}_{3} \cdot x \mathrm{In}_{2} \mathrm{O}_{3} \mathrm{ss}$ & C-type & Cubic \\
\hline \multirow[t]{2}{*}{$\mathrm{Er}_{2} \mathrm{O}_{3}-\mathrm{In}_{2} \mathrm{O}_{3}$} & \multirow[t]{2}{*}{$50: 50$} & $\begin{array}{r}800 \\
1350\end{array}$ & $\begin{array}{r}20 \\
6\end{array}$ & & & \\
\hline & & 1600 & 41 & $(1-x) \mathrm{Er}_{2} \mathrm{O}_{3} \cdot x \mathrm{In}_{2} \mathrm{O}_{3} s$ & C-type & Cubic \\
\hline \multirow[t]{2}{*}{$\mathrm{Tm}_{2} \mathrm{O}_{3}-\mathrm{In}_{2} \mathrm{O}_{3}$} & \multirow[t]{2}{*}{$50: 50$} & 800 & 20 & & & \\
\hline & & $\begin{array}{l}1350 \\
1600\end{array}$ & $\begin{array}{l}6 \\
4\end{array}$ & $(1-x) \mathrm{Tm}_{2} \mathrm{O}_{3} \cdot x \mathrm{In}_{2} \mathrm{O}_{3} \mathrm{ss}$ & C-type & Cubic. \\
\hline \multirow[t]{2}{*}{$\mathrm{Yb}_{2} \mathrm{O}_{3}-\mathrm{In}_{2} \mathrm{O}_{3}$} & \multirow[t]{2}{*}{$50: 50$} & 800 & 20 & & & \\
\hline & & $\begin{array}{l}1330 \\
1600\end{array}$ & $\begin{array}{l}0 \\
41\end{array}$ & $(1-x) \mathrm{Yb}_{2} \mathrm{O}_{3} \cdot x \mathrm{In}_{2} \mathrm{O}_{3} \mathrm{ss}$ & C-type & Cubic \\
\hline $\mathrm{Lu}_{2} \mathrm{O}_{3}-\mathrm{In}_{2} \mathrm{O}_{3}$ & $50: 50$ & 800 & 20 & & & \\
\hline & & $\begin{array}{l}1350 \\
1600\end{array}$ & $\begin{array}{l}6 \\
4\end{array}$ & $(1-x) \mathrm{Lu}_{2} \mathrm{O}_{3} \cdot x \mathrm{In}_{2} \mathrm{O}_{3 \mathrm{ss}}$ & C-type & Cubic ... \\
\hline
\end{tabular}

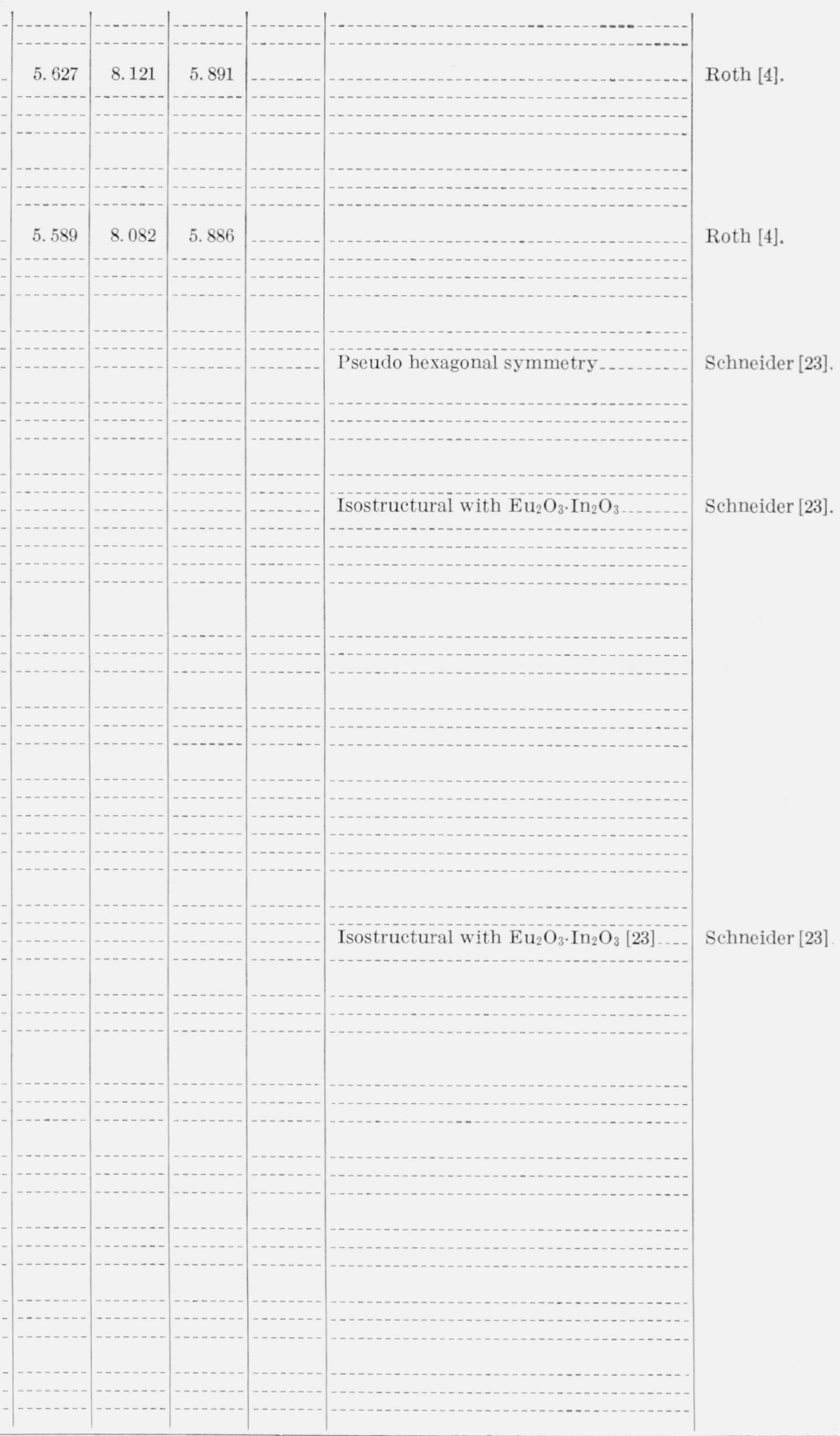

1 All specimens in present work slow cooled except where noted. Each heat treatment includes all previously listed lower temperature heatings given for the same composition.

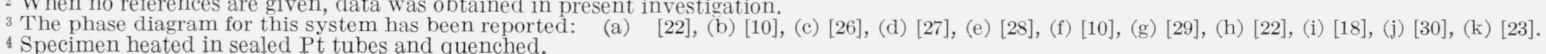



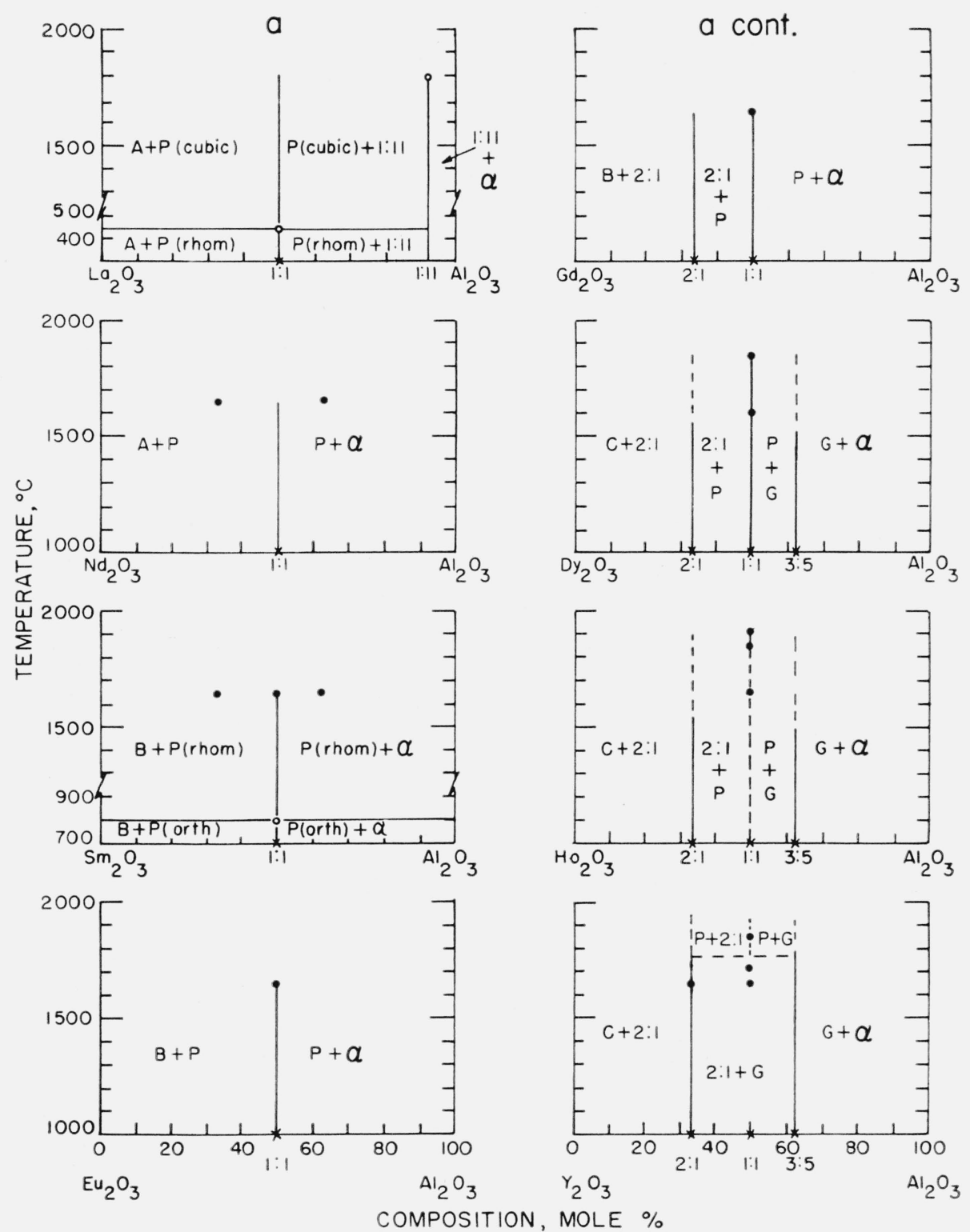

FIGURE 5. Predicted subsolidus binary phase diagrams for systems involving oxides of the trivalent cations

A-A-type rare earth oxide structure B-B-type rare earth oxide structure C-C-type rare earth oxide structure $\mathrm{G}$ - garnet type compound

1:11- beta alumina type structure

$\mathrm{P}$-perovskite type compound

$\mathrm{R}$-unknown type structure, rhombohedral symmetry

- compositions studied in present work - data taken from literature

$x$-data taken from literature for which no temperature of heat treatment is given

(a) Binary oxide systems containing $\mathrm{Al}^{+3}$ and larger cations. The following systems pertinent to this series have been previously published.
1. $\mathrm{Y}_{2} \mathrm{O}_{3}-\mathrm{Al}_{2} \mathrm{O}_{3}[22]$
3. $\mathrm{Cr}_{2} \mathrm{O}_{3}-\mathrm{Al}_{2} \mathrm{O}_{3}[26]$ 
a cont.
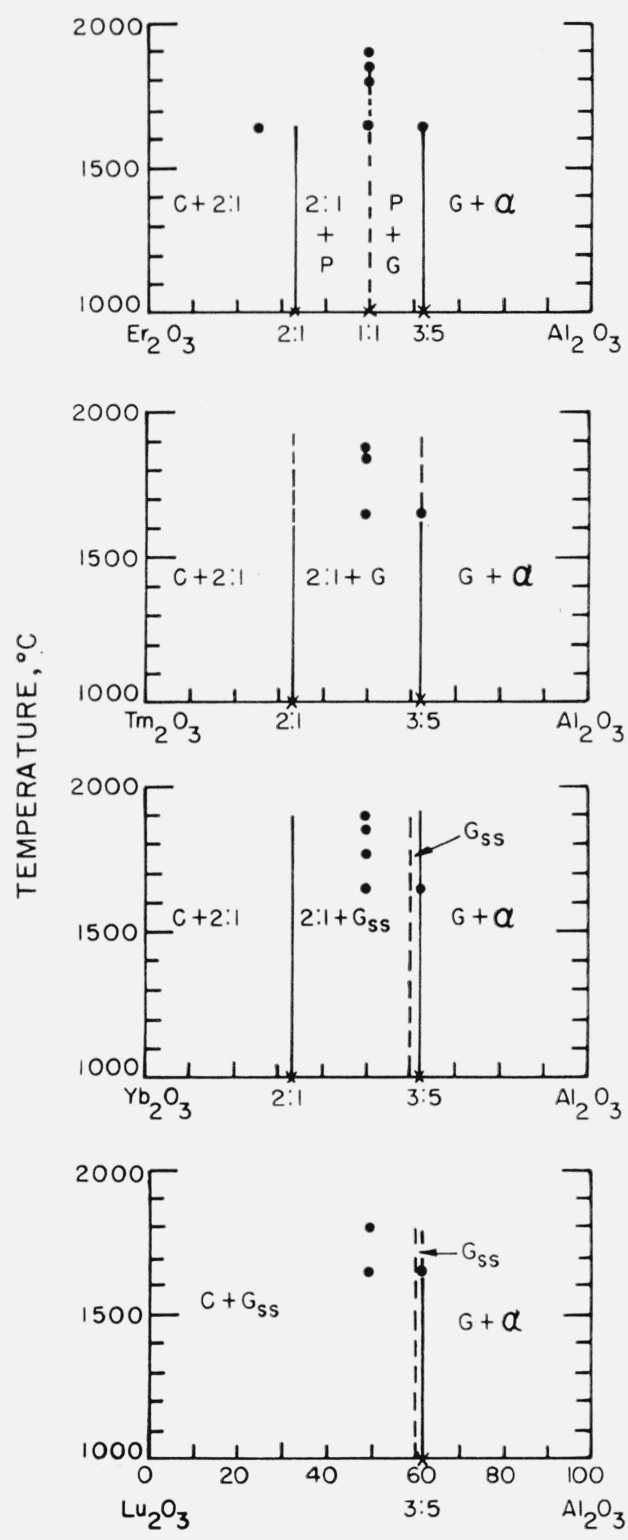

a cont
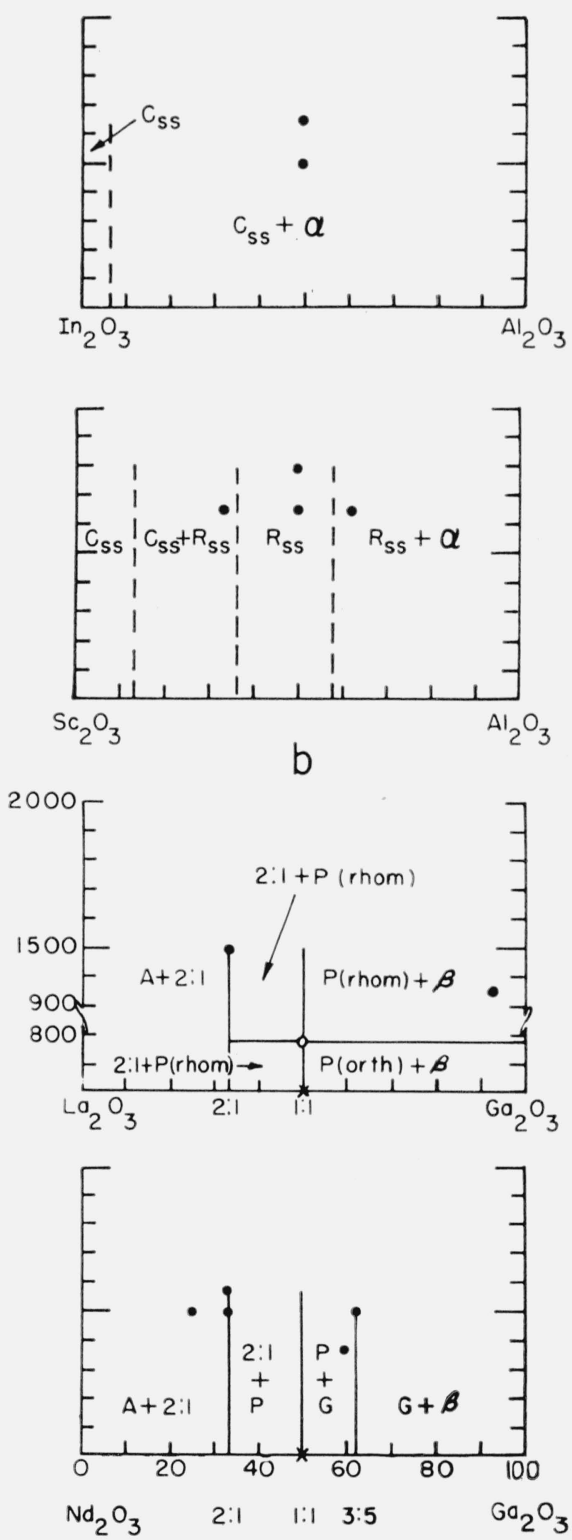

COMPOSITION, MOLE \%

Figure 5. Predicted subsolidus binary phase diagram for systems involving oxides of the trivalent cations - Continued

- compositions studied in present work - data taken from literature

$x$ - data taken from literature for which no temperature of heat treatment is

A-A-type rare earth oxide structure given

B-B-type rare earth oxide structure C-C-type rare earth oxide structure C-C-type rare earth oxide

1:11-beta alumina type structure

$\mathrm{P}$-perovskite type compound

$\mathrm{R}$ - unknown type structure, rhombohedral symmetry

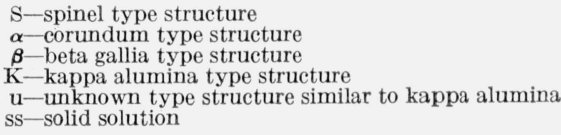

(a) Binary oxide systems containing $\mathrm{Al}^{+3}$ and larger cations. The following systems pertinent to this series have been previously published.

$$
\begin{aligned}
& \text { 1. } \mathrm{Y}_{2} \mathrm{O}_{3}-\mathrm{Al}_{2} \mathrm{O}_{3}[22] \\
& \text { 3. } \mathrm{Cr}_{2} \mathrm{O}_{3}-\mathrm{Al}_{2} \mathrm{O}_{3}[26]
\end{aligned}
$$

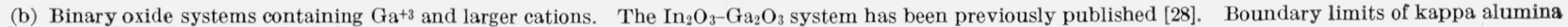
solid solution taken from Remeika [35]. 

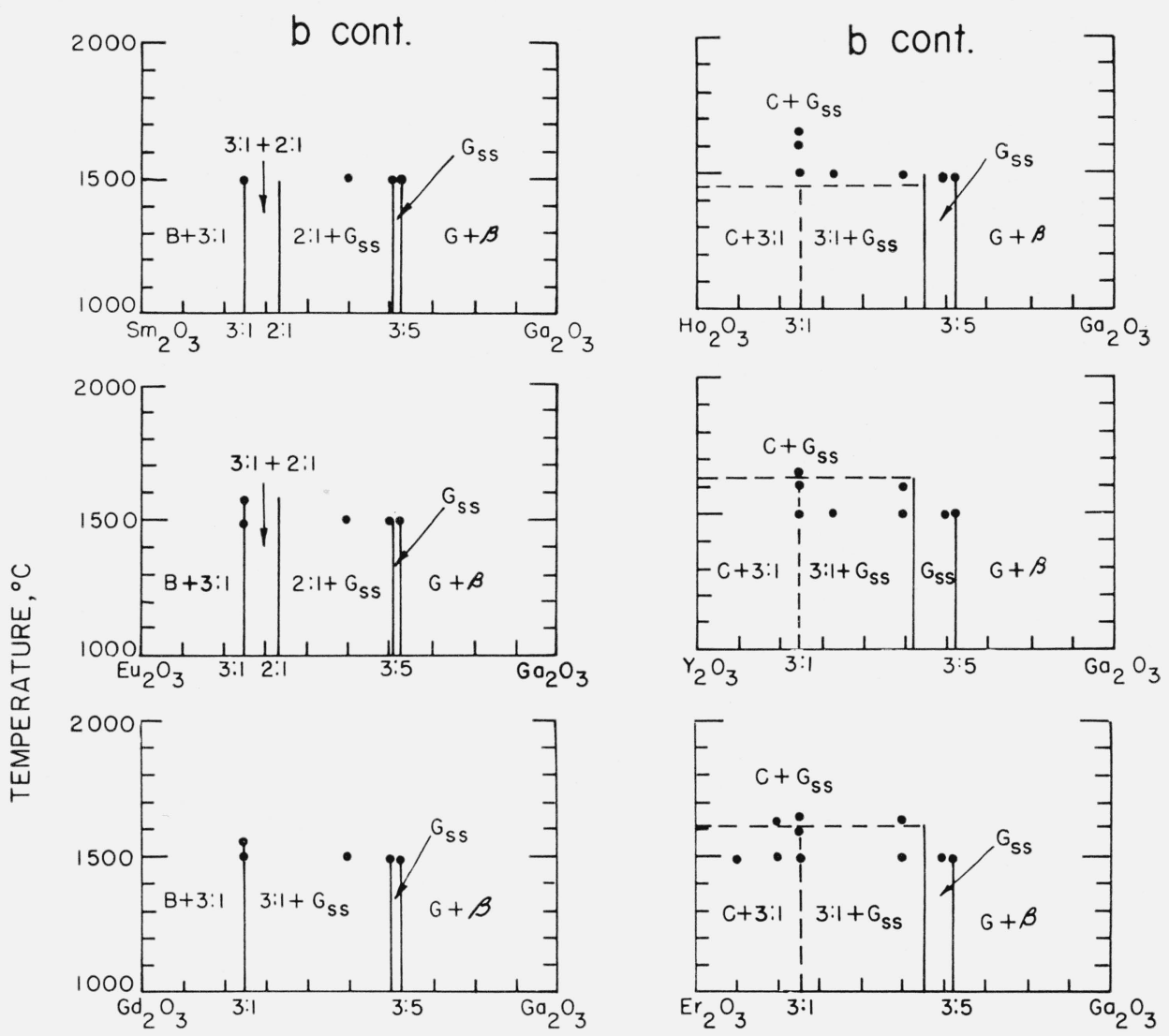

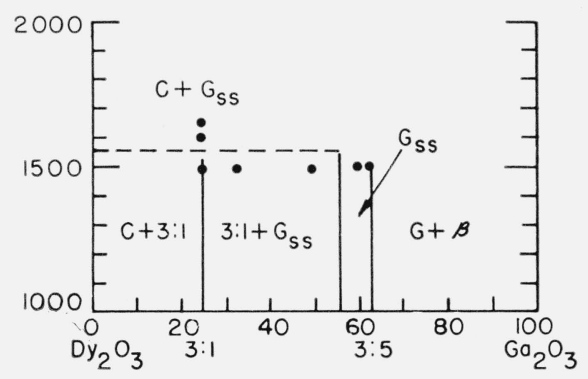

\section{COMPOSITION, MOLE \%}

Figure 5. Predicted subsolidus binary phase diagram for systems involving oxides of the trivalent cations-Continued

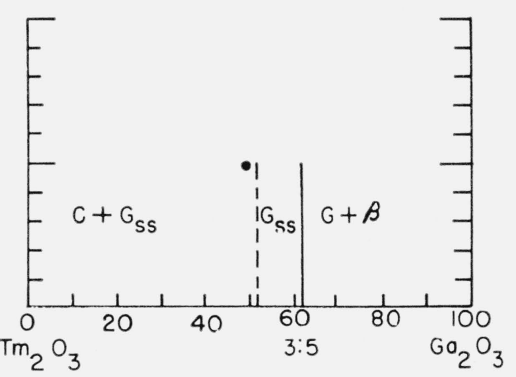

data taken from literature

- data taken from literature for which no temperature of heat treatment is given
A-A-type rare earth oxide structure C-C-type rare earth oxide structure $\mathrm{G}$ - garnet type compound

1:11- beta alumina type structure

$\mathrm{P}$-perovskite type compound.

$\mathrm{K}$-unknown type structure, rhombohedral symmetry B-B-type rare earth oxide structure

(b) Binary oxide systems containin
solid solution taken from Remeika [35].

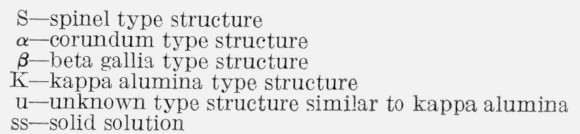



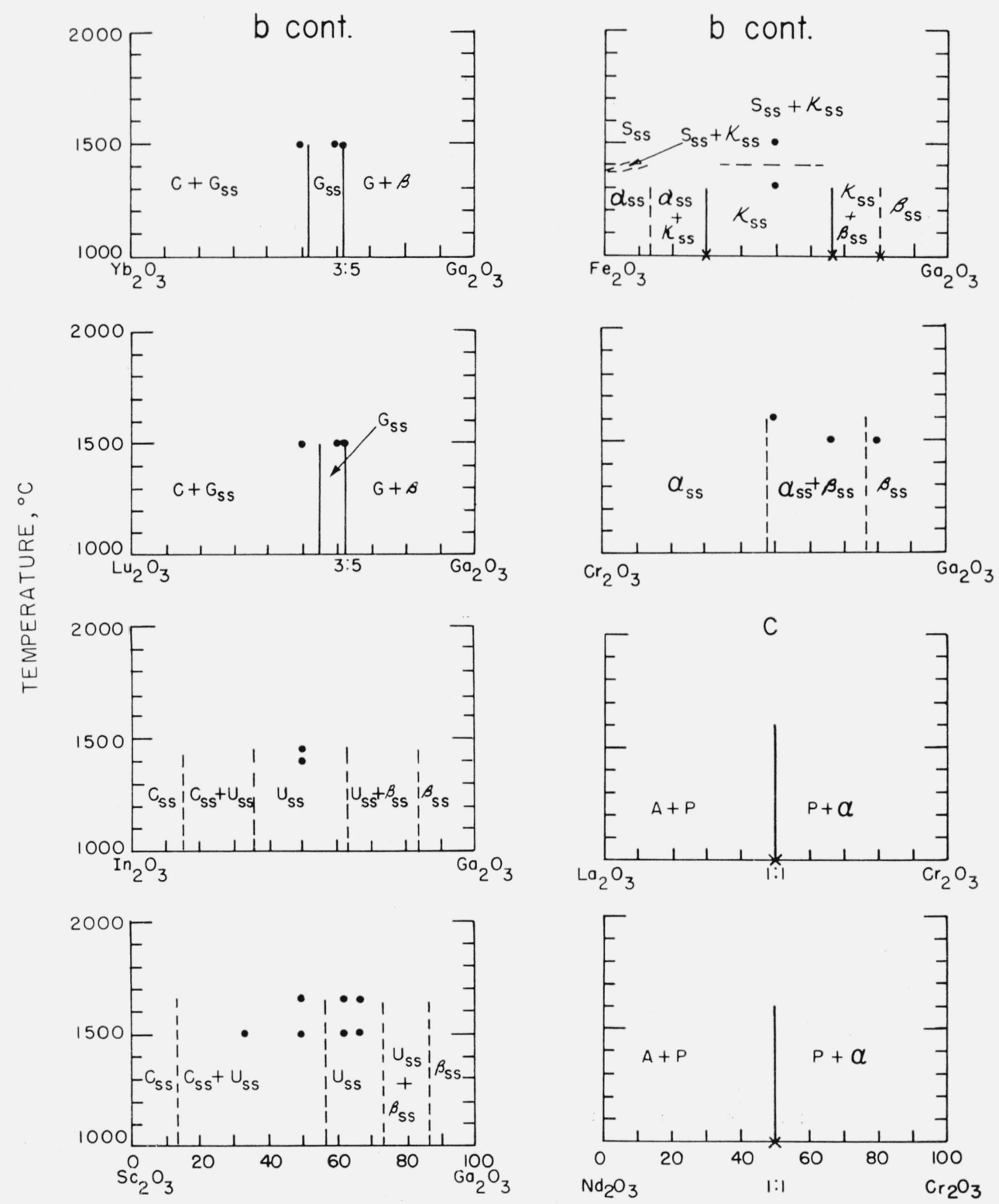

COMPOSITION, MOLE \%

Figure 5. Predicted subsolidus binary phase diagram for systems involving oxides of the trivalent cations-Continued

- compositions studied in present work - data taken from literature

wiven from literature for which no temperature of heat treatment is

A-A-type rare earth oxide structure

B-B-type rare earth oxide structure

C-C-type rare earth oxide structure

$\mathrm{G}$-garnet type compound.

1:11 - beta alumina type structure

$\mathrm{P}$-perovskite type compound

$\mathrm{R}$-unknown type structure, rhombohedral symmetry

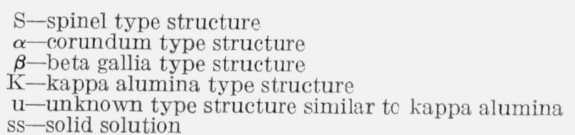

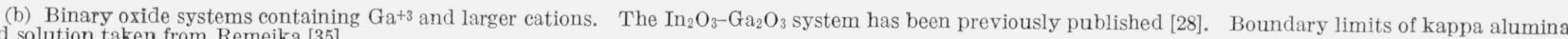
solid solution taken from Remeika [35].

(c) Binary oxide systems containing $\mathrm{Cr}^{+3}$ and larger cations. The $\mathrm{Fe}_{2} \mathrm{O}_{3}-\mathrm{Cr}_{2} \mathrm{O}_{3}$ system has been previously published [10]. 

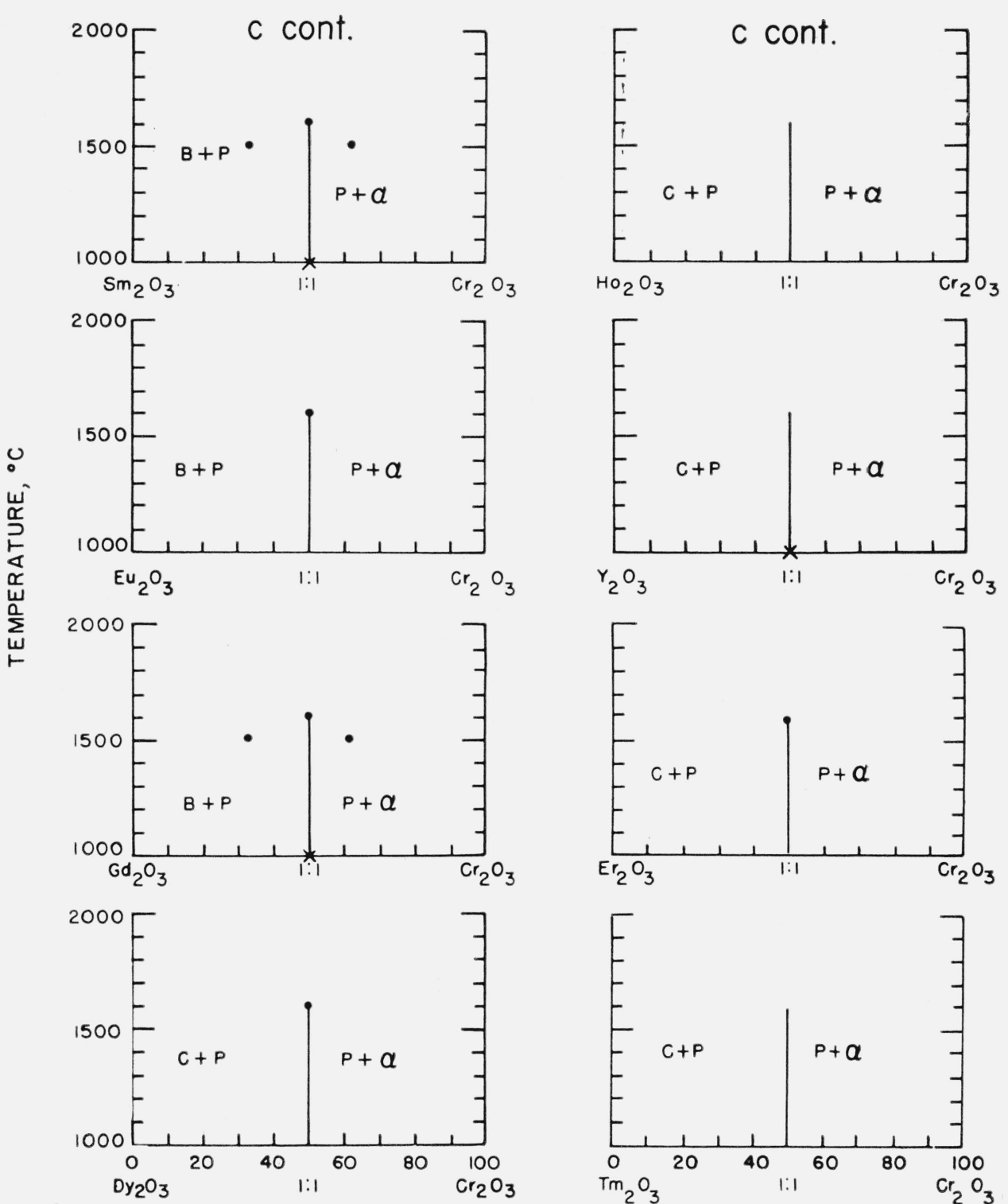

COMPOSITION, MOLE \%

FIGURE 5. Predicted subsolidus binary phase diagram for systems involving oxides of the trivalent cations - Continued

- compositions studied in present work - data taken from literature

data taken from literature for which no temperature of heat treatment is

A-A-type rare earth oxide structure
B-B-type rare earth oxide structure given

C-C-type rare earth oxide structure

$\mathrm{G}$-garnet type compound

1:11- beta alumina type structure

$\mathrm{P}$-perovskite type compound

$\mathrm{R}$-unknown type structure, rhombohedral symmetry

\author{
S-spinel type structure \\ $\alpha-$ corundum type structure \\ $\boldsymbol{\beta}$-beta gallia type structure \\ $\mathrm{K}$-kappa alumina type structure \\ $\mathrm{u}$ - unknown type structure similar to kappa alumina \\ ss-solid solution
}

(c) Binary oxide systems containing $\mathrm{Cr}^{+3}$ and larger cations. The $\mathrm{Fe}_{2} \mathrm{O}_{3}-\mathrm{Cr}_{2} \mathrm{O}_{3}$ system has been previously published [10]. 

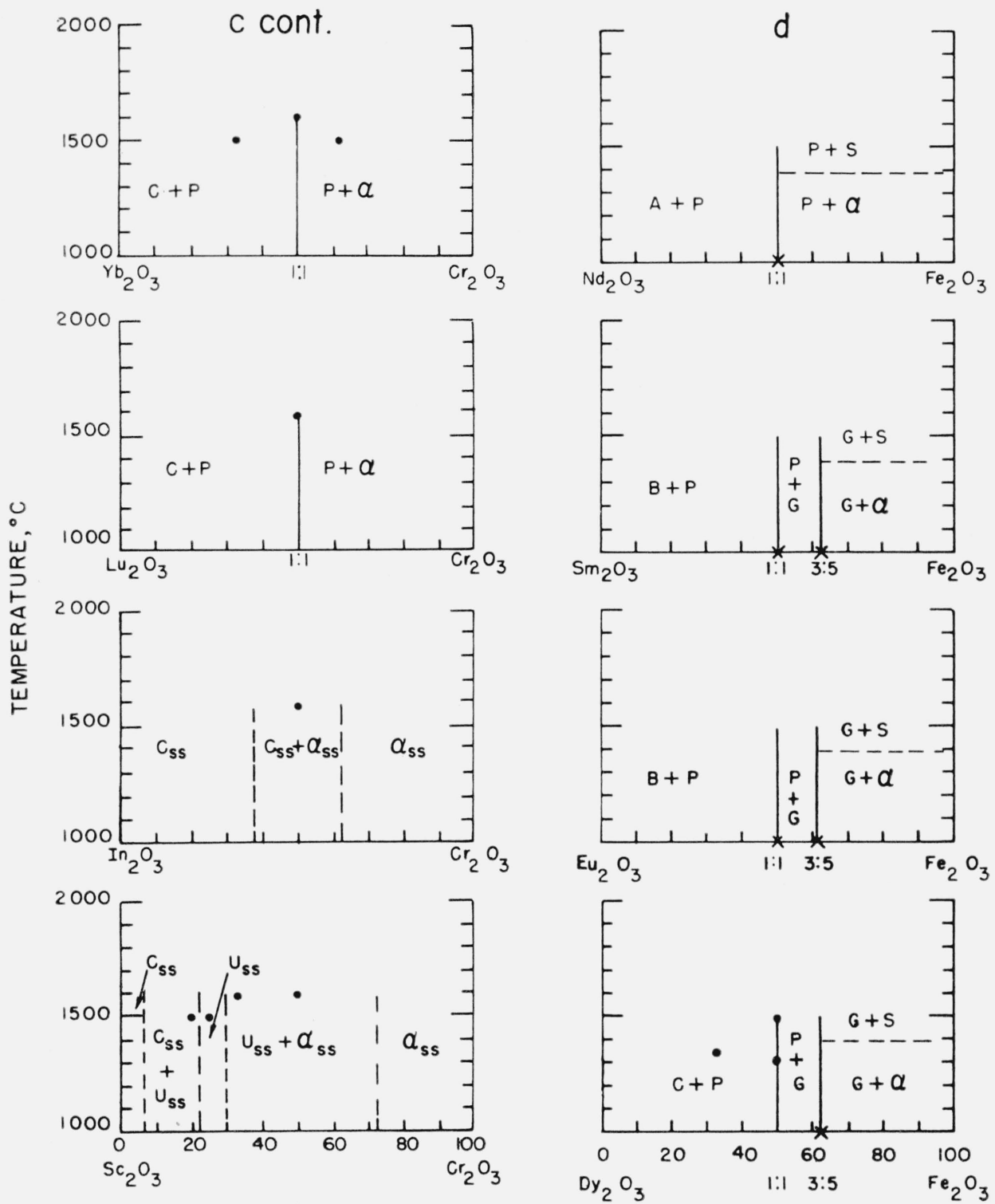

\section{COMPOSITION, MOLE \%}

Figure 5. Predicted subsolidus binary phase diagram for systems involving oxides of the trivalent cations-Continued

- compositions studied in present work

- data taken from literature given

A-A-type rare earth oxide structure B-B- ype rare earth oxide structure C-C-type rare earth oxide structure

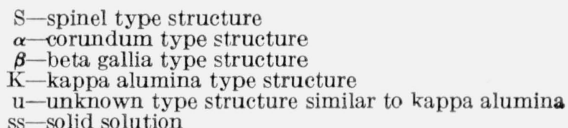

(c) Binary oxide systems containing $\mathrm{Cr}^{+3}$ and larger cations. The $\mathrm{Fe}_{2} \mathrm{O}_{3}-\mathrm{Cr}_{2} \mathrm{O}_{3}$ system has been previously published [10].

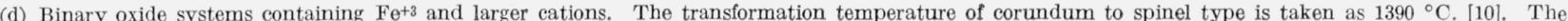
following systems pertinent to this series have been previously published:

$$
\text { 1. } \mathrm{La}_{2} \mathrm{O}_{3}-\mathrm{Fe}_{2} \mathrm{O}_{3}[29]
$$$$
\text { 3. } \mathrm{Y}_{2} \mathrm{O}_{3}-\mathrm{Fe}_{2} \mathrm{O}_{3}[18
$$

4. $\mathrm{Se}_{2} \mathrm{O}_{3}-\mathrm{Fe}_{2} \mathrm{O}_{3}[30$ 

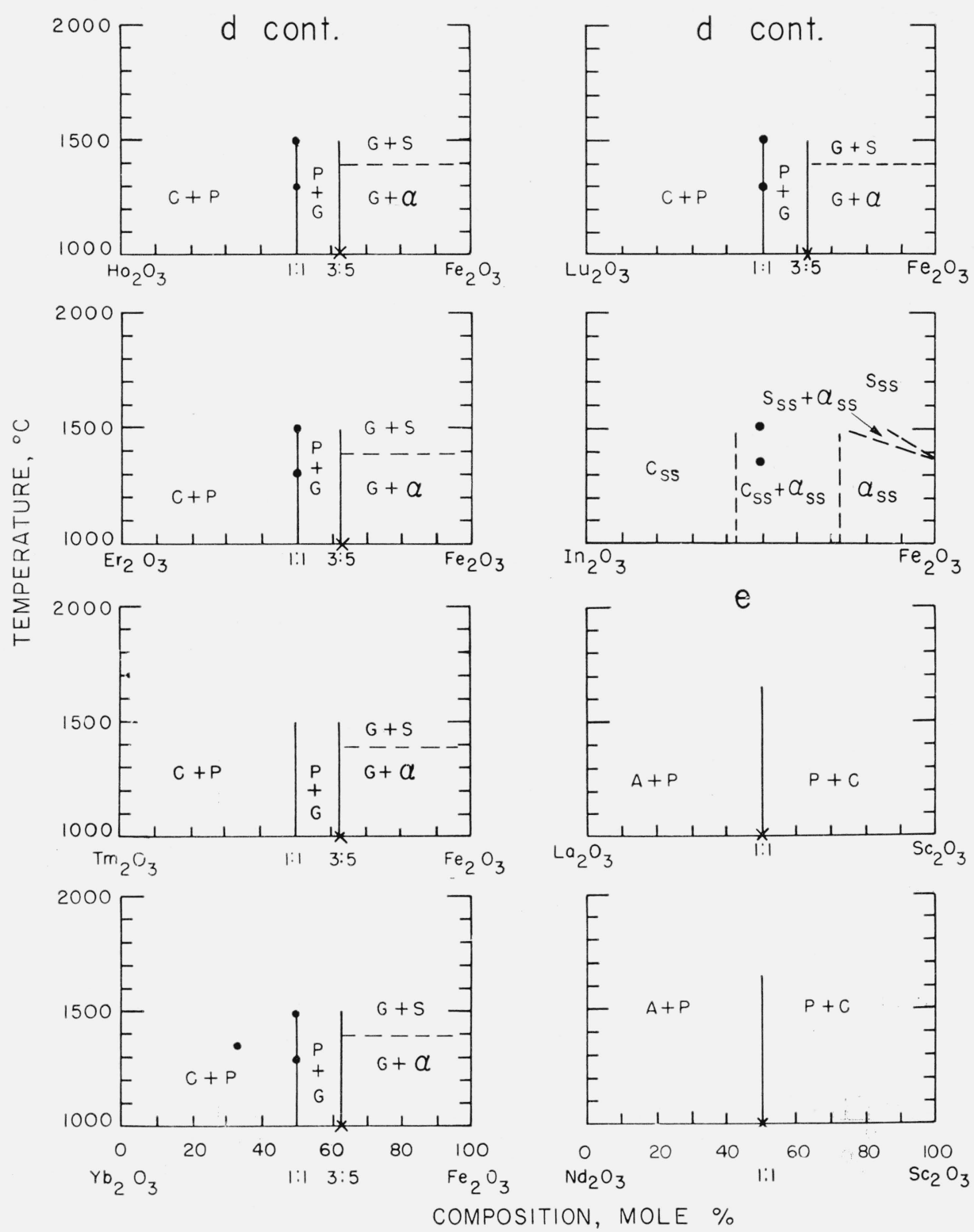

Figure 5. Predicted subsolidus binary phase diagram for systems involving oxides of the trivalent cations-Continued

- compositions studied in present work

- data taken from literature

$x$-data taken from literature for which no temperature of heat treatment is given

A-A-type rare earth oxide structure B-B-type rare earth oxide structure C-C-type rare earth oxide structure $\mathrm{G}$-garnet type compound

1:11- beta alumina type structure

$\mathrm{P}$-perovskite type compound

$\mathrm{R}$-unknown type structure, rhombohedral symmetry

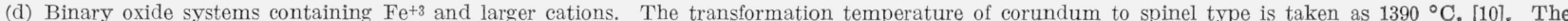
following systems pertinent to this series have been previously published:

$$
\begin{aligned}
& \text { 1. } \mathrm{Ia}_{2} \mathrm{O}_{3}-\mathrm{Fe}_{2} \mathrm{O}_{3}[29] \\
& \text { 2. } \\
& \mathrm{Gd}_{2} \mathrm{O}_{3}-\mathrm{Fe}_{2} \mathrm{O}_{3}[22]
\end{aligned}
$$

(e) Binary oxide systems containing $\mathrm{Sc}^{+3}$ and larger cations, $\alpha$-corundum type structure

$\mathrm{K}$-kappa alumina type structure

$\mathrm{u}$ - unknown type structure similar to kappa alumina ss-solid solution
S-spinel type structure

$\beta$-beta gallia type structure

3. $\mathrm{Y}_{2} \mathrm{O}_{3}-\mathrm{Fe}_{2} \mathrm{O}_{3}[18]$

4. $\mathrm{Se}_{2} \mathrm{O}_{3}-\mathrm{Fe}_{2} \mathrm{O}_{3}[30]$ 
e cont.
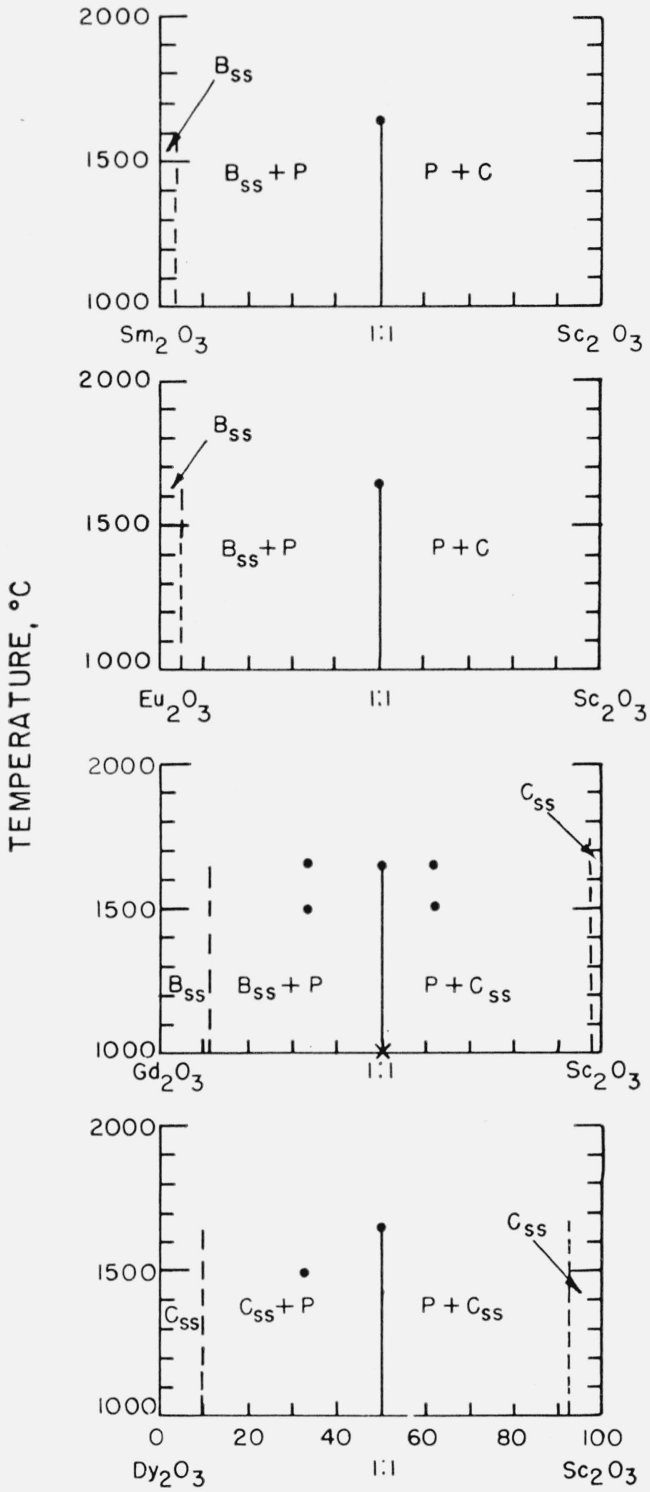

e cont.
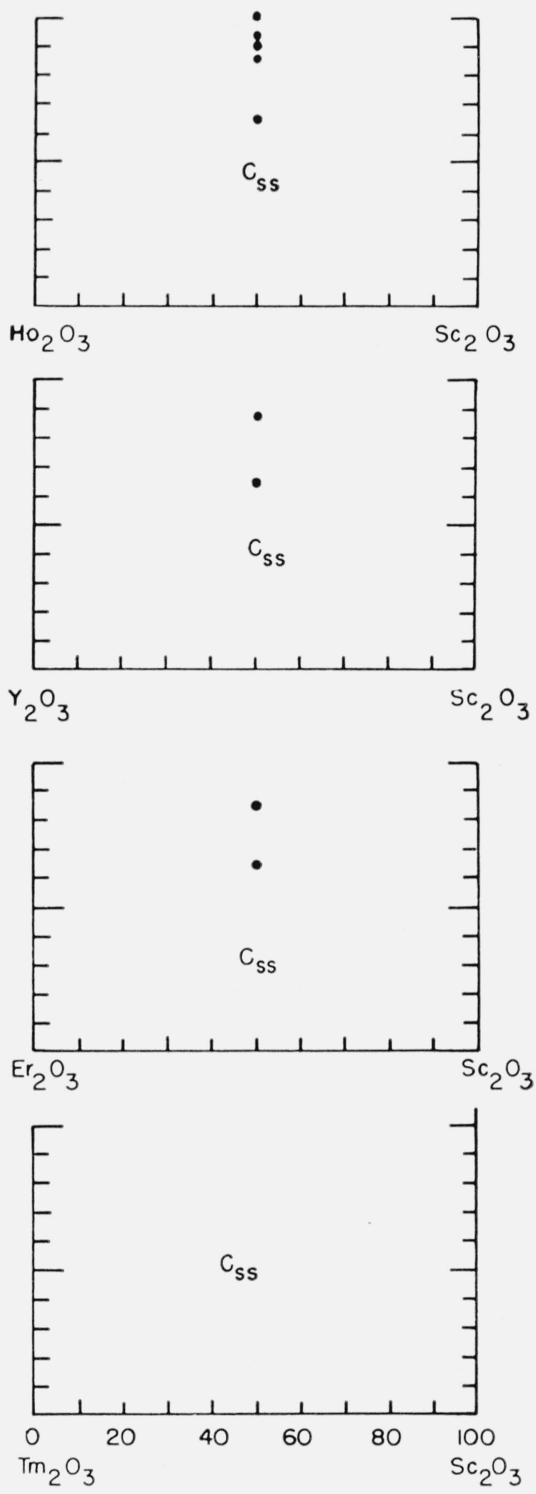

COMPOSITION, MOLE \%

FIGURe 5. Predicted subsolidus binary phase diagram for systems involving oxides of the trivalent cations-Continued

- compositions studied in present work - data taken from literature

$x$ - data taken from literature for which no temperature of heat treatment is given

A-A-type rare earth oxide structure B-B-type rare earth oxide structure C-C-type rare earth oxide structure G-garnet type compound

[1:11-beta alumina type structure
$\mathrm{P}$ - perovskite type compound

$\mathrm{R}$-unknown type structure, rhombohedral symmetry

(e) Binary oxide systems containing $\mathrm{Sc}^{+3}$ and larger cations.
S-spinel type structure

$\alpha$ - corundum type structure $\beta$-beta gallia type structure

$\mathrm{K}$-kappa alumina type structure

$\mathrm{u}$ - unknown type structure similar to kappa alumina ss-solid solution 
e cont.
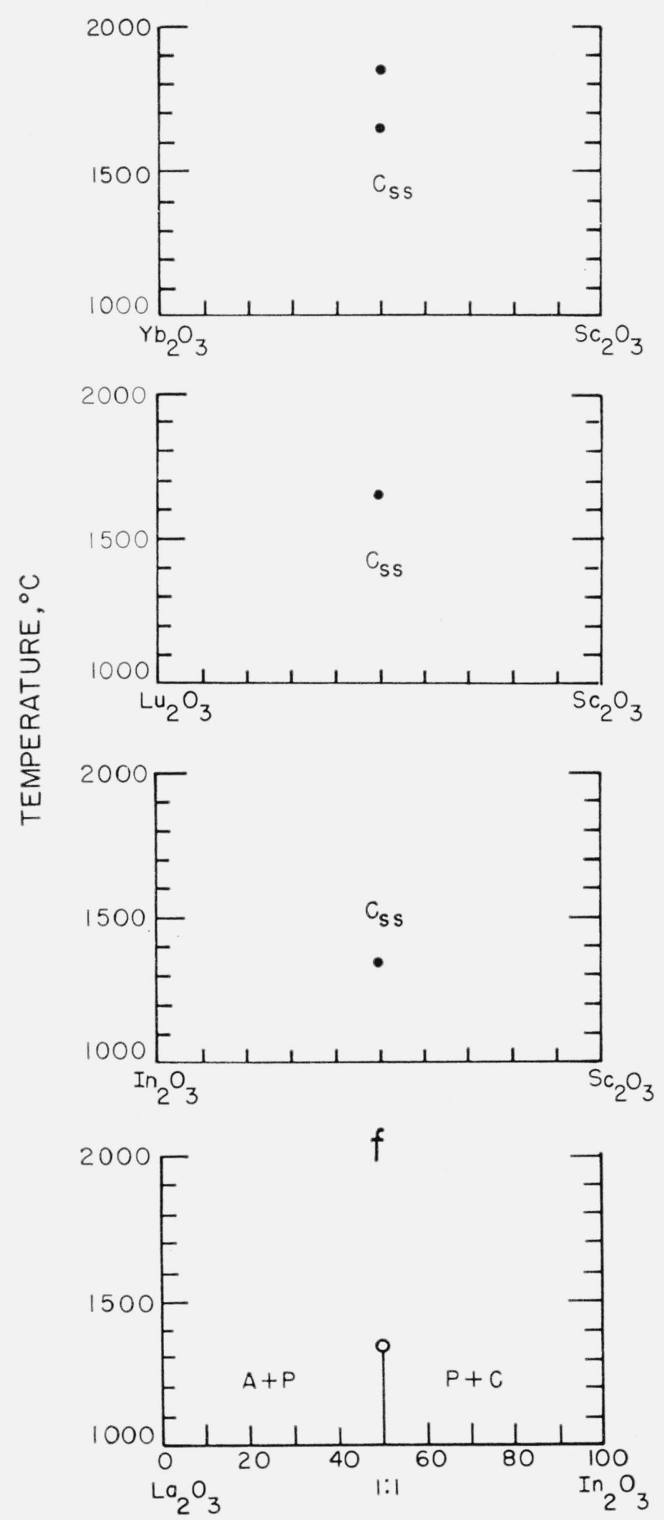

f cont.
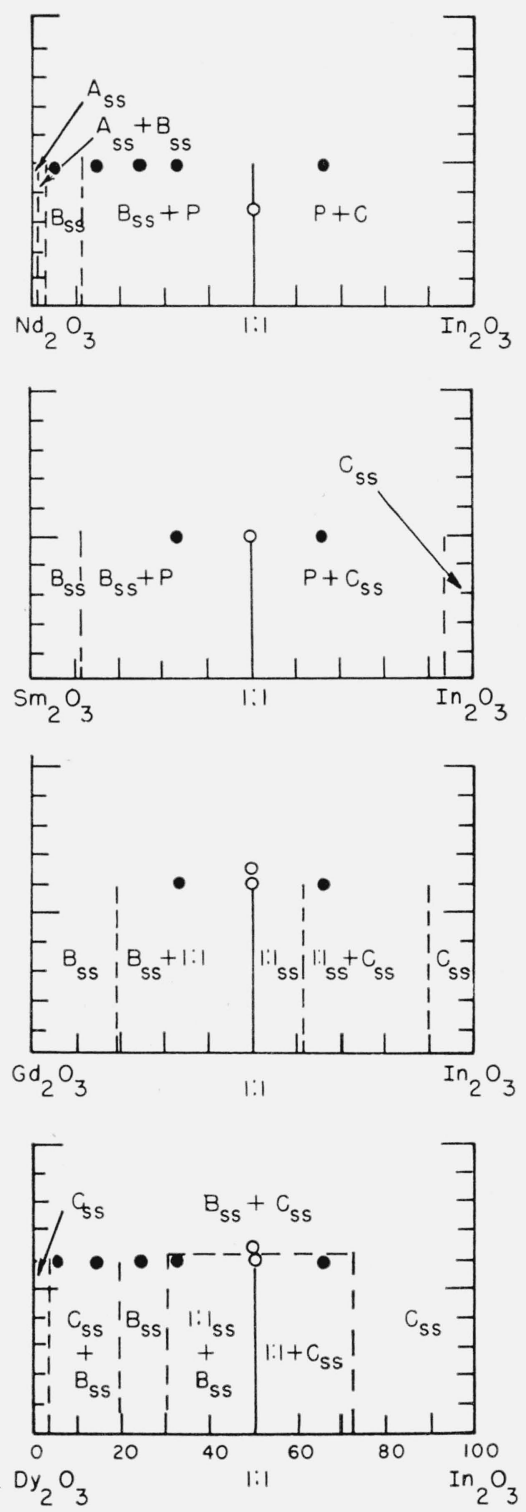

COMPOSITION, MOLE \%

FIgURE 5. Predicted subsolidus binary phase diagram for systems involving oxides of the trivalent cations-Continued

A-A-type rare earth oxide structure B-B-type rare earth oxide structure C-C-type rare earth oxide structure G-garnet type compound

1:11-beta alumina type structure

1:11-beta alumina type structure

$\mathrm{P}$-perovskite type compound
$\mathrm{R}$-unknown type structure, rhombohedral symmetry -compositions studied in present work

- data taken from literature

- data taken from literature for which no temperature of heat treatment is given

(e) Binary oxide systems containing $\mathrm{Sc}^{+3}$ and larger cations.

(f) Binary oxide systems containing In ${ }^{+3}$ and larger cations. The $\mathrm{Eu}_{2} \mathrm{O}_{3}-\mathrm{In}_{2} \mathrm{O}_{3}$ system to be published [23].
$\mathrm{S}-$-spinel type structure $\alpha$-corundum type structure $\beta$-beta gallia type structure

$\mathrm{K}$-kappa alumina type structure

$\mathrm{u}$ - unknown type structure similar to kappa alumina

ss-solid solution 

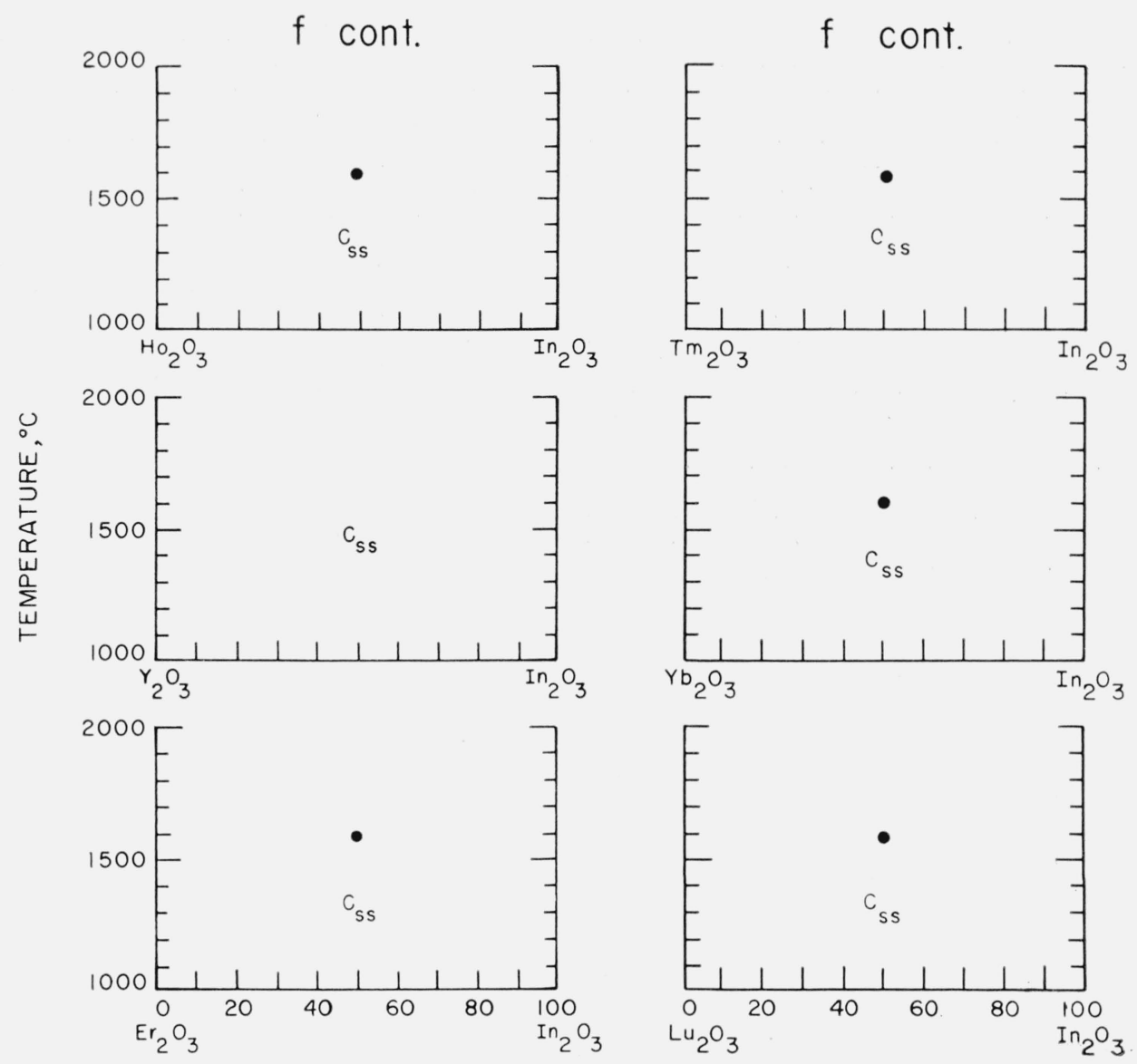

COMPOSITION, MOLE \%

Figure 5. Predicted subsolidus binary phase diagram for systems involving oxides of the trivalent cations-Continued

A-A-type rare earth oxide structure

B-B-type rare earth oxide structure C-C-type rare earth oxide structure G-garnet type compound

11-beta alumina type structure

$\mathrm{P}$-perovskite type compound

R-unknown type structure, rhombohedral symmetry

compositions studied in present work data taken from literature

$x$ - data taken from literature for which no temperature 0 theat treatment is given

S- spinel type structure

$\alpha$-corundum type structure

$\beta$ - beta gallia type structure

$\mathrm{K}$ - kappa alumina type structure

$\mathrm{u}$ - unknown type structure similar to kappa alumina

ss-solid solution

(f) Binary oxide systems containing $\mathrm{In}^{+3}$ and larger cations. The $\mathrm{Eu}_{2} \mathrm{O}_{3}-\mathrm{In}_{2} \mathrm{O}_{3}$ system to be published [23].

\section{References}

1] S. J. Schneider and R. S. Roth, J. Research NBS $64 \mathbf{A}$, 317-332 (1960).

2] V. M. Goldschmidt, T. Barth, G. Lunde, and W. Zachariasen, Pt. VII Skrifter Norske VidenskapsAkad. Oslo I. Mat-Naturv. K1 No. 2 (1926).

3] M. L. Keith and R. Roy, Amer. Min. 39, 1-23 (1954).

4] R. S. Roth, J. Research NBS 58, 75-88 (1957).

5] S. Geller and E. A. Wood, Acta Cryst. 9, 563-568 (1956).

3] S. Geller, Acta Cryst. 10, 243-248 (1957).

7] S. Geller and V. B. Bala, Acta Cryst. 9, 1019-1025 (1956).

L. H. Ahrens, Geochim. et Cosmochim. Acta 2, 155-169 (1952).

9] R. S. Roth and S. J. Schneider, J. Research NBS $64 \mathbf{A}$, 309-316 (1960).
[10] A. Muan and S. Somiya, J. Am. Ceram. Soc. 42, 603-613 (1959).

[11] E. Mooser and W. B. Pearson, Acta Cryst. 12, 1015-1022 (1959).

[12] L. Pauling, The Nature of the Chemical Bond, 3d ed., Ithaca, N.Y., Cornell Univer. Press 98 (1960).

[13] W. Gordy and W. J. Orville, J. Chem. Phys. 24, 439-444 (1956).

[14] M. W. Shafer and R. Roy, J. Am. Ceram. Soc. 42, 563570 (1959).

[15] R. Roy, V. G. Hill, and E. F. Osborn, Ind. and Eng. Chem. 45, 819-820 (1953).

[16] J. A. W. Dalziel, J. Chem. Soc. Jun., 1993-1998 (1959).

[17] S. Geller and C. E. Miller, Acta Cryst. 13, 179-186 (1960).

[18] H. J. Van Hook, J. Am. Ceram. Soc. 44, 208-214 (1961). 
[19] A. S. Russell, W. H. Gitzen, J. W. Newsome, R. W. Ricker, V. W. Stowe, H. E. Stumpf, J. R. Wall, and P. Wallace, Tech. Paper No. 10, Aluminum Co. of Amer. 1-65 (1956).

[20] H. M. Richardson, F. Ball, and G. R. Rigby, Trans. Intern. Cer. Congr., 3d Congr., Paris 173-181 (1954).

[21] E. A. Wood, Acta Cryst. 13, 682 (1960).

[22] I. Warshaw and R. Roy, J. Am. Ceram. Soc. 42, 434-438 (1959).

[23] S. J. Schneider, to be published in J. Research NBS 65A, No. 5 (Sept-Oct 1961

[24] V. M. Goldschmidt, F. Ulrich, and T. Barth, Pt IV Skrifter Norske Videnskaps-Akad. Oslo I. Mat. Naturv. K1 No. 5 (1925).

[25] H. C. Stumpf, A. S. Russell, J. W. Newsome, and C. M. Tucker, Ind. and Eng. Chem. 42, 1398-1403 (1950).

[26] E. N. Bunting, NBS J. Res. 6, 947-949 (1931).

[27] V. G. Hill, R. Roy, and E. F. Osborn, J. Am. Ceram. Soc. 35, 135-142 (1952).

[28] V. M. Goldschmidt, T. Barth, and G. Lunde, Pt V, Skrifter Norske Videnskaps-Akad. Oslo I. Mat. Naturv. K1 No. 7 (1925).
[29] V. L. Moruzzi and M. W. Shafer, J. Am. Ceram. Soc. 4: 367-372 (1960).

[30] J. Cassedanne and H. Forestier, Compt. Rend. 250, 2898 $2900(1960)$

[31] R. S. Roth and S. Hasko, J. Am. Ceram. Soc. 41, 14 (1958).

[32] I. Warshaw and R. Roy, Abstract Bull. Am. Ceran Soc. 4, 169 (1959). Also: Presentation of paper, 61st Ann. Meet. An Ceram. Soc., Chicago, May 19 (1959).

[33] H. S. Yoder and M. L. Keith, Am. Min. 36, 519-53 (1951).

[34] F. Bertaut and F. Forrat, Compt. Rend. 244, 96-9 (1957).

[35] J. P. Remeika, Suppl. J. Appl. Phys. 315, 263-264 (1960

(Paper 65A4-116 